\title{
The acute effect of propanil on reproductive hormones, ovarian gene expression and splenic cells in C57BI/6 female mice
}

\author{
Malia Danielle Berg \\ West Virginia University, mberg1@mix.wvu.edu
}

Follow this and additional works at: https://researchrepository.wvu.edu/etd

Part of the Endocrinology Commons, and the Toxicology Commons

\section{Recommended Citation}

Berg, Malia Danielle, "The acute effect of propanil on reproductive hormones, ovarian gene expression and splenic cells in C57BI/6 female mice" (2019). Graduate Theses, Dissertations, and Problem Reports.

7421.

https://researchrepository.wvu.edu/etd/7421

This Thesis is protected by copyright and/or related rights. It has been brought to you by the The Research Repository @ WVU with permission from the rights-holder(s). You are free to use this Thesis in any way that is permitted by the copyright and related rights legislation that applies to your use. For other uses you must obtain permission from the rights-holder(s) directly, unless additional rights are indicated by a Creative Commons license in the record and/ or on the work itself. This Thesis has been accepted for inclusion in WVU Graduate Theses, Dissertations, and Problem Reports collection by an authorized administrator of The Research Repository @ WVU. For more information, please contact researchrepository@mail.wvu.edu. 
The acute effect of propanil on reproductive hormones, ovarian gene expression and splenic cells in C57BI/6 female mice

\author{
Malia Danielle Berg
}

Thesis submitted to the Davis College of Agriculture, Natural Resources and Design at West Virginia University in partial fulfillment of the requirements for the degree of Master of Science in Reproductive Physiology

\author{
Robert A. Dailey, Ph.D., Chair \\ Ida Holásková, Ph.D. \\ Rosana Schafer, Ph.D. \\ Jennifer Franko, Ph.D.
}

Division of Animal and Nutritional Sciences

Morgantown, West Virginia

2019

Keywords: Propanil, heat-killed Streptococcus pneumoniae, reproductive hormones, splenocytes, and steroidogenic gene expression

Copyright 2019 Malia Danielle Berg 


\begin{abstract}
The acute effect of propanil on reproductive hormones, ovarian gene expression and splenic cells in C57BI/6 female mice
\end{abstract}

\title{
Malia Danielle Berg
}

Earlier evidence indicates exposure to propanil, a post-emergent herbicide used on rice and wheat fields, increases the number of antibody-secreting cells (ASC) in the spleen of mice after immunization with heat-killed Streptococcus pneumoniae (HKSP, $2 \times 10^{8} \mathrm{CFU}$ ). Interestingly, an intact hypothalamic-pituitary-gonadal (HPG) axis is required for this immune response assessed on day 7-10 after immunization in female mice. Hence, an overarching premise is that propanil arbitrates the connection between the reproductive and immune system by altering the concentration of hormones involved in the HPG axis, which may then affect the populations of splenic cells. Hypotheses were tested with C57BI/6 female mice vaccinated with HKSP and assigned among four treatment groups ( 6 mice each) in a $2 \times 2$ factorial arrangement. The first factor represented propanil treatment (propanil, control), and the second factor represented two periods $(24 \mathrm{~h}, 72 \mathrm{~h}$ ) of collection for blood, spleen, ovaries, and oviducts after immunization. At $24 \mathrm{~h}$, propanil decreased the number of splenocytes contrary to increased cell populations at day 7-10 observed in earlier experiments. Also, propanil increased serum concentrations of prolactin and progesterone but decreased estradiol, corroborated by corresponding changes in mRNA for steroid synthesis in ovaries. To determine if these effects depend on gonadotropin-releasing hormone $(\mathrm{GnRH})$ receptor binding, we utilized the $\mathrm{GnRH}$ antagonist (antide; $60 \mu \mathrm{g} \mathrm{s.q.),} \mathrm{given} \mathrm{to} \mathrm{C57BI/6} \mathrm{female}$ mice before the same immunization with HKSP. In ovaries, antide increased gene expression of inflammatory and anti-inflammatory cytokines and markers (Csf1, Cxcl1, Cxcl10, II-10, Irf-1, TIr2), interacted with propanil effect in HKSP-challenged mice on the expression of serum amyloid A by reducing propanil's effects. In the spleen, antide decreased the number of T-cells, and in the presence of HKSP decreased the number of B-cells and the percentage of monocytes and macrophages. Thus, GnRH receptors may be necessary for the acute responses ( 24 hours) to propanil and support a hypothesis that immune and reproductive systems interact in female mice challenged with the bacterial vaccine. 


\section{Acknowledgments}

I want to thank my advisor, Dr. Robert A. Dailey, for all his guidance and wisdom through my three years at WVU. I have learned so much about reproductive physiology and significant reasoning over my three years at WVU from the advice of my advisor. I am grateful to have had this opportunity to study reproductive physiology in your lab at WVU.

Secondly, I would like to thank Dr. Ida Holásková for all her time and expertise in statistics. I would not have been able to conduct my experiment without your help. I will always be grateful for all the guidance and support I receive over the past three years.

Thirdly, I would like to thank my other committee members, Dr. Rosana Schafer and Dr. Jennifer Franko, for helping me conduct my experiments and always be available to assist when I needed guidance analyzing my immunology data. I would also like to thank Dr. Keith Inskeep for taking a chance on me to be a successful graduate student.

To the graduate students in my office, Denzel Middleton, Brynnan Russ, Andrew Weaver, Camren Maierle, and Roger Rohrbaugh, I would like to thank you for always encouraging and supporting me throughout my time at WVU. I would also like to thank the other reproductive physiology grad students, Heather Baldwin, Lindsay Gross, Jaelyn Current, and Mingxiang Zhang. Thank you for always being supportive when I needed assistance with my research.

Lastly, I would like to thank my family for always supporting me and answering the phone when I needed to talk about how my project didn't go as planned. I would not have made it through my masters without the people listed above. Thank you to everyone who helped me through my masters; I will forever be grateful. 


\section{Table of Contents}

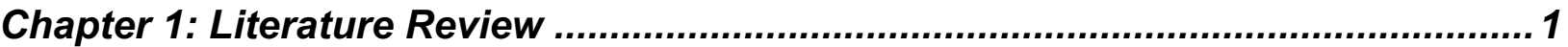

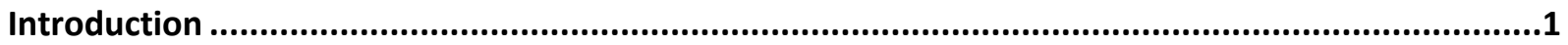

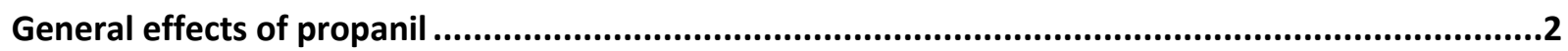

Propanil dose-response and mode of exposure ...............................................................................

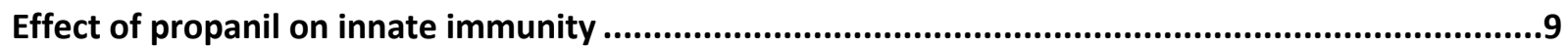

Propanil effects on primary and secondary lymphoid organs and cellularity ..................................12

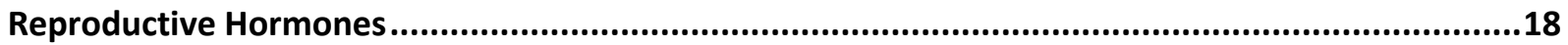

Effects of propanil on the endocrine, including reproductive, system .........................................24

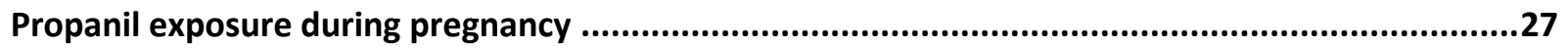

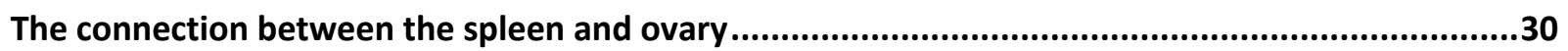

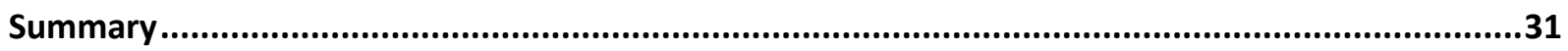

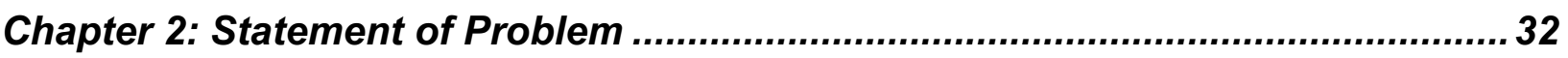

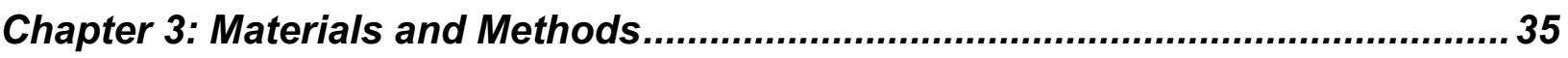

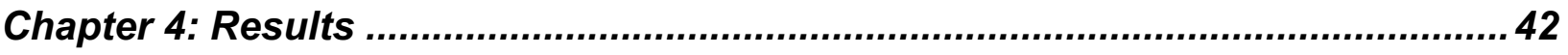

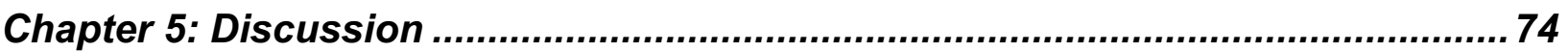

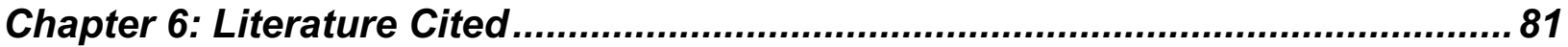




\section{List of Tables}

Table 1. Primer sequences for genes analyzed by qRT-PCR

Table 2. Effect of propanil and time after HKSP/propanil on spleen weight, spleen cell populations, systemic hormones, and ovarian gene expression for trial 1

Table 3. Effect of propanil and time after saline/propanil on spleen weight, spleen cell populations, systemic hormones, and ovarian gene expression for mice treated with saline.

Table 4. Effect of propanil and time after HKSP/propanil on spleen weight, spleen cell populations, systemic hormones, and ovarian gene expression for mice treated with HKSP 


\section{List of Figures}

Figure 1. Chemical structure and hepatic metabolism of propanil ........................... 1

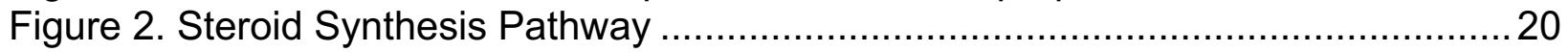

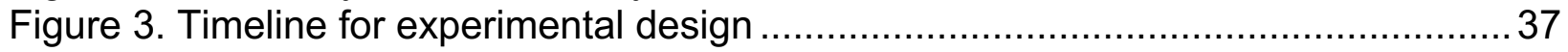

Figure 4. Spleen Weights post-HKSP immunization +/- propanil exposure .................56

Figure 5. Total number of splenocytes post-HKSP immunization +/- propanil exposure58

Figure 6. Percentage and total number of B cells in the spleen 24 hours post-HKSP

immunization $+/$ - propanil exposure

Figure 7. Percentage and total number of $\mathrm{CD}^{+} \mathrm{T}$ cells in the spleen 24 hours post-

HKSP immunization +/- propanil exposure

Figure 8. Percentage and total number of $\mathrm{CD}^{+} \mathrm{T}$ cells in the spleen 24 hours postHKSP immunization $+/$ - propanil exposure

Figure 9. Percentage and total number of $C D 11 b^{+} T$ cells in the spleen 24 hours postHKSP immunization +/- propanil exposure.

Figure 10. Serum hormone concentrations post-HKSP immunization +/- propanil exposure

Figure 11. Effect of propanil and antide exposures in +/- HKSP immunization on ovarian weights and ovarian area

Figure 12. Ovarian histology after mice received six doses of antide .......................65

Figure 13. Propanil and antide exposures on uterine weights +/- HKSP immunization 66

Figure 14. Expression of steroid synthesis enzymes and Gnrhr post-HKSP immunization $+/$ - propanil exposure

Figure 15. Expression at 24 hours post-exposure of genes involved in prolactin synthesis

Figure 16. Expression at 24 hours post-exposure of Lcn2

Figure 17. Expression at 24 hours post-exposure of genes involved in extracellular matrix remodeling and immune regulation.....

Figure 18. Proposed model for acute propanil-mediated effects on HPG axis leading to immunomodulation 


\section{List of Abbreviations}

$\begin{array}{ll}\mu g & \text { Microgram } \\ \mu \mathrm{M} & \text { Micrometer } \\ \text { Adamts1 } & \text { A Disintegrin And Metalloproteinase with Thrombospondin Motifs 1 } \\ \text { Actb } & \text { B-Actin } \\ \text { ALP } & \text { Alkaline Phosphatase } \\ \text { AP-1 } & \text { Activating Protein-1 } \\ \text { ASC } & \text { Antibody-secreting cell } \\ \text { ASM } & \text { Accelerator Mass Spectrometry } \\ \text { AST } & \text { Aspartate Aminotransferase } \\ \text { BFU-E } & \text { Erythroid Burst-forming Unit } \\ \text { bp } & \text { Base Pairs } \\ \text { BSA } & \text { Bovine Serum Albumin } \\ \text { C } & \text { Celsius } \\ \text { Car3 } & \text { Carbonic Anhydrase 3 } \\ \text { CCl2 } & \text { C-C Motif Chemokine Ligand 2 } \\ \text { CCL7 } & \text { C-C Motif Chemokine Ligand 7 } \\ \text { CFB } & \text { Complement Factor B } \\ \text { CFD } & \text { Complement Factor D } \\ \text { CFU-E } & \text { Erythroid Colony-forming Unit } \\ \text { CFU-G } & \text { Granulocyte Progenitor Cell } \\ \text { CFU-M } & \text { Macrophage Progenitor Cell } \\ \text { CFU-S } & \text { Myeloid Stem Cell } \\ \text { CHI3L1 } & \text { Chitinase 3 like 1 } \\ \text { CL } & \text { Corpus Luteum } \\ \text { Cm } & \text { Centimeter } \\ \text { CNS } & \text { Central Nervous System } \\ \text { ConA } & \text { Concanavalin A } \\ \text { CSF } & \text { Colony Stimulating Factor } \\ \text { Csf1 } & \text { Colony Stimulating Factor 1 } \\ \text { Cxcl1 } & \text { C-X-C Motif Chemokine Ligand 1 } \\ \text { Cxcl10 } & \text { C-X-C Motif Chemokine Ligand 10 } \\ \text { Cyp111b1 } & \text { Cytochrome P450 11B1 } \\ \text { Cyp17a1 } & \text { Cytochrome P450 17A1 } \\ \text { Cyp19a1 } & \text { Cytochrome P450 19A1 } \\ \text { DCA } & \text { 3,4-Dichloroaniline } \\ \text { DCPA } & \text { 3,4-dichloropropionanilide } \\ \text { Dhcr7 } & \\ \text { DHT } & \text { Dihydrotestosterone } \\ & \end{array}$




$\begin{array}{ll}\mathrm{E}_{2} & \text { Estradiol } \\ \text { EDN2 } & \text { Endothelin 2 } \\ \text { ER } & \text { Estrogen Receptor } \\ \text { FSH } & \text { Follicle Stimulating Hormone } \\ \text { GM } & \text { Granulocyte-macrophage-progenitor cell } \\ \text { GUCA2B } & \text { Guanylate Cyclase Activator 2B } \\ \text { GnRH } & \text { Gonadotropin Releasing Hormone } \\ \text { GnRHR } & \text { Gonadotropin Releasing Hormone Receptor } \\ \text { HCL } & \text { Hydrochloric Acid } \\ \text { H\&E } & \text { Hematoxylin and Eosin } \\ \text { HKSP } & \text { Heat-killed Streptococcus pneumoniae } \\ \text { Hprt1 } & \text { Hypoxanthine-guanine phosphoribosyltransferase } \\ \text { HSD } & \text { Honestly Significant Difference } \\ \text { Hsd17b2 } & \text { Hydroxysteroid 17-Beta Dehydrogenase 2 } \\ \text { Hsd17b7 } & \text { Hydroxysteroid 17-Beta Dehydrogenase 7 } \\ \text { HPG } & \text { Hypothalamic-pituitary-gonadal } \\ \text { IACUC } & \text { Institutional Animal Care and Use Committee } \\ \text { ICAM1 } & \text { Intercellular Adhesion Molecule 1 } \\ \text { IL-2 } & \text { Interleukin 2 } \\ \text { IL-3 } & \text { Interleukin 3 } \\ \text { IL-6 } & \text { Interleukin 6 } \\ \text { IL-10 } & \text { Interleukin 10 } \\ \text { IL-12 } & \text { Interleukin 12 } \\ \text { INF } & \text { Interferon } \\ \text { lo } & \text { Ionophore A23187 } \\ \text { i.p. } & \text { Melanocortin 2 Receptor Accessory Protein } \\ \text { Iff } & \text { Intraperitoneal } \\ \text { kg } & \text { Interferon regulatory factor 1 } \\ \text { L } & \text { Kilogram } \\ \text { Lcn2 } & \text { Liter } \\ \text { LDH } & \text { Lipocalin 2 } \\ \text { LPS } & \text { Lactate Dehydrogenase } \\ \text { LS } & \text { Lipopolysaccharide } \\ \text { m } & \text { Least Square } \\ \text { MDA } & \text { Meter } \\ \text { mg } & \text { Malondialdehyde } \\ \text { MLR } & \text { Milligram } \\ \text { mL } & \text { Milliter } \\ \text { mmol } & \text { MRAP }\end{array}$




$\begin{array}{ll}\text { NFAT } & \text { Nuclear Factor of Activated T-cell } \\ \text { NFkB } & \text { Nuclear Factor kappa B } \\ \text { NK } & \text { Natural Killer Cell } \\ \text { ng } & \text { Nanogram } \\ \text { NRQ } & \text { Normalized Relative Quantity } \\ \text { P4 } & \text { Progesterone } \\ \text { PBMC } & \text { Peripheral Blood Mononuclear Cell } \\ \text { PBS } & \text { Phosphate Buffered Saline } \\ \text { PC } & \text { Polysaccharide Phosphorylcholine } \\ \text { PGE2 } & \text { Prostaglandin E2 } \\ \text { PGF } & \text { Prostaglandin F2 alpha } \\ \text { PMN } & \text { Polymorphonuclear Neutrophils } \\ \text { ppm } & \text { Part per million } \\ \text { PspA } & \text { Pneumococcal surface protein A } \\ \text { RBC } & \text { Red Blood Cell } \\ \text { rCSF } & \text { recombinant Colony-stimulating Factor } \\ \text { RQ } & \text { Relative Quantity } \\ \text { Saa3 } & \text { Serum Amyloid A 3 } \\ \text { SEM } & \text { Standard Error of the Means } \\ \text { SERPINA3 } & \text { Serpin Family A Member 3 } \\ \text { Socs3 } & \text { Suppressor of cytokine signaling 3 } \\ \text { S100a8 } & \text { S100 calcium-binding protein A8 } \\ \text { S100a9 } & \text { S100 calcium-binding protein A9 } \\ \text { TD } & \text { T-dependent } \\ \text { TI-2 } & \text { T-independent } \\ \text { TIr2 } & \text { Toll-like receptor 2 } \\ \text { TNF } & \text { Tumor Necrosis Factor } \\ \text { Tnfaip3 } & \text { Tumor Necrosis Factor, Alpha-induced Protein 3 } \\ \text { VCAM1 } & \text { Vascular Cell Adhesion Molecule 1 } \\ \text { XPNPEP2 } & \text { X-prolyl Aminopeptidase } \\ \Delta \triangle C q & \text { delta-delta Quantification Cycle } \\ & \end{array}$




\section{Chapter 1: Literature Review}

\section{Introduction}

Propanil (3,4-dichloropropionanilide, DCPA, Figure 1) is a selective herbicide from the acetanilide chemical family (Zhao et al., 1998) used in the United States mainly to regulate broadleaf weeds on rice fields (Bartha and Pramer, 1970; U.S.

Environmental Protection Agency, 2003). The particular properties of propanil depend on the ability of plants to metabolize it, thus resisting the propanil-induced inhibition of photosynthesis (Prado et al., 1992), oxidative damage, and cell death. Rice plants contain sufficient enzymatic apparatus to metabolize propanil; for example, rice leaves contain about 60-times higher amounts of the aryl acylamidase enzyme than barnyard grass weeds (Frear and Still, 1968). Propanil exposure in humans via ingested rice seed is minimal. Exposure is limited to agricultural workers, applicators, propanilmanufacturing workers, as well as residents near treated farms, and via direct accidental or intentional ingestion. Past evidence from clinical case reports, laboratory animal studies, and ex-vivo and in-vitro models indicate that propanil has adverse effects on mammalian physiology. The current studies were designed to expand the understanding of the effect of propanil on the immune system and its interaction with the reproductive system in female mice. Individually, we examined the acute effects of propanil and hypothalamic hormone-binding on pituitary and ovarian hormones, ovarian gene expression, and the cell populations in the spleen. 


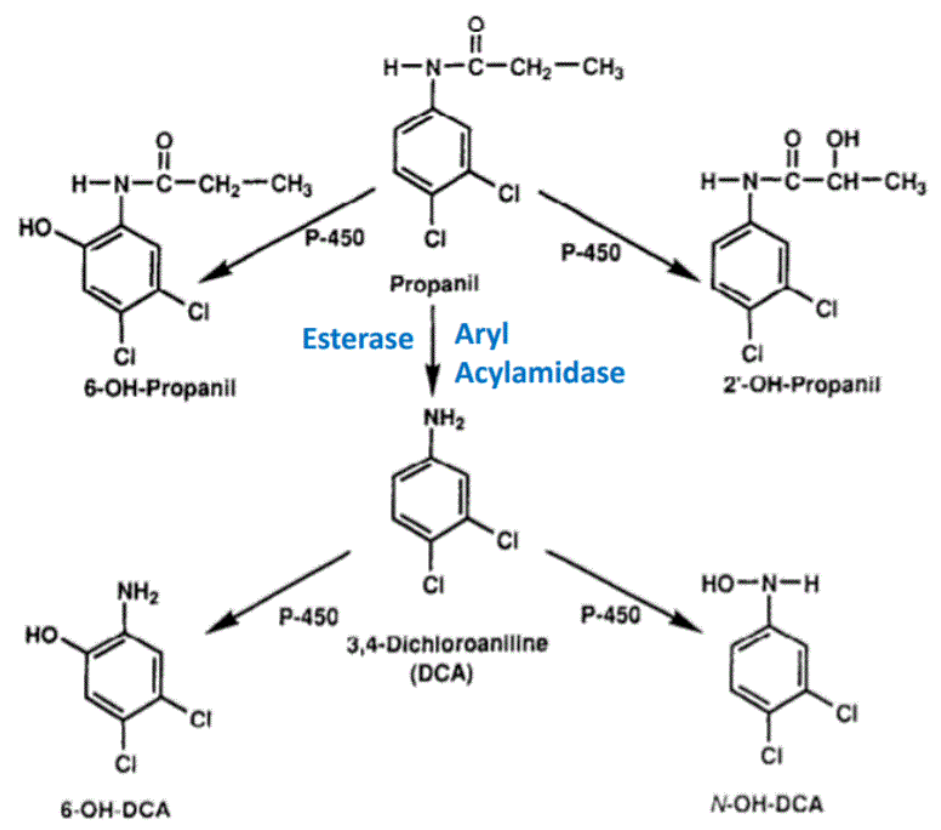

Figure 1. Chemical structure and hepatic metabolism of propanil, modified (McMillan et al., 1990)

\section{General effects of propanil}

Workers involved with manufacturing and applicators of propanil in agriculture are at the highest risk of exposure, while there have been clinical reports of intentional or accidental ingestion of propanil (Eddleston et al., 2002; Roberts et al., 2009) and other non-application exposure (M. Richards, G. Y. H. McClure, T. L, 2001; Roberts et al., 2009).

Upon propanil's entry into the mammalian system, the first step of the metabolism takes place in microsomes of the liver (Williams and Jacobson, 1966; McMillan et al., 1990). The process is enzymatic hydrolysis catalyzed by acylamidase (Williams and Jacobson, 1966; Singleton and Murphy, 1973; McMillan et al., 1990; Lewis et al., 2013) cleaving the propionic side chain and subsequent formation of 3,4- 
Dichloroaniline (DCA, Figure 1) and propionate. Some authors refer to the enzyme leading to DCA formation as esterase or use esterase and acylamidase interchangeably (McMillan et al., 1990; Roberts et al., 2009) due to two factors: esterase inhibitors block DCA formation (Matsunaka, 1968, DuBois et al., 1968; Singleton and Murphy, 1973; McMillan et al., 1990), and some enzymes have both (esterase and acylamidase) activities (Rajesh et al., 2003).

While the first metabolic step (conversion of DCPA to DCA and propionate) protects propanil-resistant plants like rice, tomatoes, lettuce, sugar beets, okra, peppers and occurs in soil as well (Bartha and Pramer, 1967; Hoagland et al., 1974, 2004), the generation of metabolites in mammals has undesirable physiological consequences. Central nervous system (CNS) suppression, including loss of the righting reflex in mice, and methemoglobinemia and hemolytic anemia have been documented in humans (Morse et al., 1979; Eddleston et al., 2002) and mice (Singleton and Murphy, 1973; Chow and Murphy, 1975) and occur within 30 minutes to 4-8 hours of oral or intraperitoneal $(1.3 \mathrm{mmol} / \mathrm{kg}$ or $200-800 \mathrm{mg} / \mathrm{kg}$ ) exposure to propanil. Methemoglobinemia is higher than usual ( $1 \%$ of hemoglobin) concentration of methemoglobin in the systemic circulation (Curry, 1982). Methemoglobin is an abnormal form of unoxygenated hemoglobin, in which the iron is in the ferric $\left(\mathrm{Fe}^{+}\right)$rather than the ferrous $\left(\mathrm{Fe} 2^{+}\right)$state and cannot carry oxygen or carbon dioxide (Curry, 1982). This condition can lead to blue-brown discoloration of the skin and mucous membranes, cyanosis (above $1.5 \%$ ), hypoxia (60\%), and, in extreme cases (higher than $70-80 \%$ ) is lethal (Curry, 1982). Clinical accounts from a Sri Lanka medical center reported 16 human cases of severe propanil poisoning from ingestion with clinical features such as 
confusion, reduced consciousness, cyanosis, and development of respiratory depression and death. Laboratory tests demonstrated increased methemoglobin $(\mathrm{Hb})$ levels, alanine, and aspartate transaminases, which were more than twice the upper limit and indicative of severe liver damage (Eddleston et al., 2002). In vivo (Weisburger and Weisburger, 1973) and ex vivo oxidation of hemoglobin by propanil and its metabolites, such as DCA, N-Hydroxy-3,4-dichloroaniline, and 6-Hydroxy-3,4dichloroaniline (Figure 1), were demonstrated in rat liver microsomes and isolated rat erythrocytes (McMillan et al., 1990). Hemolytic anemia is an abnormal decrease in the number of red blood cells (RBC) (Uthman and Uthman, 1998). The survival of ${ }^{51} \mathrm{Cr}$ labelled and transfused RBC in rats decreased in a dose-dependent pattern by intraperitoneal (i.p.) administration of propanil or DCA (McMillan et al., 1991; Eddleston et al., 2002). Also, erythrocyte survival was markedly reduced by i.p. administration or in vitro exposure to $\mathrm{N}$-hydroxy-3,4-dichloroaniline. When rats were subjected to three months of various concentrations of propanil mixed into their diet at 3,300 and 10,000 parts per million (ppm), hematologic findings showed an increase in polychromatophilia, more stained cells with specific dyes as compared to controls (Ambrose et al., 1972). This indicated the presence of immature forms of red blood cells not typically found in peripheral blood. Collectively, evidence from clinical cases and research indicates that metabolites of propanil are necessary for the induction of both methemoglobinemia and hemolytic anemia in mammals. The lack of oxygen delivery, depending on dose and length of exposure, may lead to other organ system pathologies.

Additional effects of propanil detectable in circulation are related to the liver, where the majority of propanil metabolism occurs. For instance, increased serum 
concentrations of alkaline phosphatase (ALP) and aspartate aminotransferase (AST) were measured in male Sprague-Dawley rats when given $50 \mathrm{mg}$ (i.p.) of propanil daily for 10 days (Santillo et al., 1995). The enzyme ALP mediates the break-down of proteins AST, a key enzyme of amino acid metabolism, is concentrated in heart and liver tissues. Both enzymes are used to assess liver function clinically, and increased levels indicate cellular damage of the liver. Microsomes from the liver, brain, and kidneys of propanil-treated rats (50 mg i.p. daily for 10 days) were examined for lipid peroxidation by measuring the malondialdehyde (MDA), a conventional marker of oxidative stress. Peroxidation in liver microsomes was increased by $95 \%$, and in brain microsomes by $36 \%$, as compared to rats injected with only corn oil (Santillo et al., 1995). No difference was observed in kidney microsomes. Also, a decrease in cholesterol and triglycerides in the serum of propanil-treated rats was seen, which could be due to the hepatic damage or direct oxidative effect of propanil on cholesterol and possibly on triglycerides (Santillo et al., 1995). Another study with F344 rats established that the propanil metabolite, DCA with the addition of hydrochloric acid $(\mathrm{HCl})$ moiety (DCA HCl salt), increased ALT activity at 0.8 and $1.0 \mathrm{mmol} / \mathrm{kg}$ doses within 24 hours (Valentovic et al., 1997), indicating liver damage. Histological examination of liver demonstrated loss of nuclei from hepatocytes $(0.8 \mathrm{mmol} / \mathrm{kg})$ and necrosis $(1.0$ $\mathrm{mmol} / \mathrm{kg})$.

Decreased urine output and increased kidney weight were observed, and blood urea nitrogen increased in a dose-dependent manner in DCA HCl-salt-treated rats. High infiltration of neutrophils and RBCs were detected using the hematoxylin and eosin (H\&E) staining in the bladder, indicative of nephrotoxicity (Valentovic et al., 1997). The 
same group demonstrated that the addition of hydrochloric acid $(\mathrm{HCl})$ moiety to DCA did not modify DCA toxicity. Albino Swiss mice fed doses 75,150 , or $300 \mathrm{mg} / \mathrm{kg}$ of propanil had a dose-related histopathological alteration in the liver and kidney (Cakici and Akat, 2013). Biometric analyses, such as measurement of the number of central filtering units, glomeruli/renal corpuscle, and the number of nuclei per hepatic cell, were determined. The congestion in both the cortex and medulla and mononuclear cell infiltration into the kidney were gradual from the low to the high dose, and glomerular loss and degeneration were evident in propanil-treated mice. The changes to the liver included swelling, intracellular vacuoles, nucleus loss, an increase in the number of Kupffer cells, and liver congestion. An increase in liver weight and swelling was observed in a subchronic oral toxicity study, when albino rats had propanil mixed into their diet, ranging from 0 to 10,000 ppm (Ambrose et al., 1972); the increase in spleen, liver and heart size was observed at 10,000 ppm. The same group established the median lethal dose of propanil in rats (the $L D_{50} \pm \mathrm{SD}$ ) to be $1,384 \pm 99 \mathrm{mg} / \mathrm{kg}$ and $1,217 \pm 8 \mathrm{mg} / \mathrm{kg}$ for dogs, within three days following gastric intubation (Ambrose et al., 1972). The evidence from rat and mice studies lead to the conclusion that propanil caused liver damage and nephrotoxicity.

Similar markers of liver damage and metabolic stress were detected in European eels (Anguilla anguilla) exposed to sublethal propanil in the aquaria water $(3.16 \mathrm{mg} / \mathrm{L}$, 1/10 of 96-hr LC50) for 72 hours. Increases in cortisol, lactate dehydrogenase (LDH) from 24 hours to 48 hours, ALP from 24 hours through hour 168, and AST from hour 2 through hour 168 with a spike at hour 72 were detected in plasma when compared to controls (Sancho et al., 2017). The LDH enzyme is involved in the conversion of sugar 
into energy and resides typically inside the cells. Upon cellular damage, it is released into the plasma. Besides liver damage, protein, cholesterol, and energy metabolism were negatively affected, indicative of overall, multiple organ toxicity. The dose of propanil, $3.16 \mathrm{mg} / \mathrm{L}$, was about a quarter of the concentration following agricultural application of $12 \mathrm{mg} / \mathrm{L}$ in rice paddies in Spain. However, it was much higher (30-60 times) than propanil concentrations of $50-100 \mu \mathrm{g} / \mathrm{L}$ measured in drainage waters, where the fish may be exposed. Thus, the evidence from the eels may be more pharmacological than physiological (Sancho et al., 2017).

In summary, exposure to propanil via oral (rats, dogs, and humans) intraperitoneal (rats and mice) and aquatic environment (eels), depending on the dose, has adverse effects on oxygen-caring capacity of RBCs via methemoglobinemia, decrease of RBCs, decrease in liver function, kidney structure, energy metabolism and cholesterol concentration. Marked changes in the amount of cholesterol and triglycerides produced by the liver or metabolized in the blood may have other functional consequences; for example, it could lead to an increase in inflammatory markers or a decrease in steroid hormone production.

\section{Propanil dose-response and mode of exposure}

The propanil doses experienced by non-applicators or humans not involved with propanil manufacturing are not well defined (Malerba, 2002). Earlier studies reported a propanil reference risk dose in humans of $0.005 \mathrm{mg} / \mathrm{kg} /$ day in the rice-producing paddies area, $0.1-0.228 \mu \mathrm{g} / \mathrm{l}$ in river samples, and $0.0003 \mathrm{mg} / \mathrm{kg}$ of propanil in leafy vegetables (Johnson et al., 1984; Gartrell et al., 1986). As propanil is used extensively 
in rice production in the Mississippi River delta region, the airborne drift during aerial application may pose a health concern to farming families (McClure et al., 2001). Exposure of families living at rice farms in Arkansas was measured inside and near the house, at an intermediate distance $(30 \mathrm{~m})$, and the edge of the rice fields after the aerial propanil application (M. Richards, G. Y. H. McClure, T. L, 2001). The amount of propanil increased with the decreasing distance to the field. Inside the houses, when detectable, there were $3-7 \mu \mathrm{g}$ of propanil/400 $\mathrm{cm}^{2}$ surface per 90 minutes, near the house the concentration ranged from $3-615 \mu \mathrm{g} / 400 \mathrm{~cm}^{2}$, in the intermediate distance from the house it varied from 3 to $952 \mu \mathrm{g} / 400 \mathrm{~cm}^{2}$. The amount was the highest at the edge of the rice fields, ranging from 9 to $12,391 \mu \mathrm{g} / 400 \mathrm{~cm}^{2}$. Wind velocity and direction contributed to the large variability in the measurements. Farmers in central Italy were tested for occupational exposure to anilide pesticides, including propanil. Most (81.5\%) urine samples were positive for the propanil metabolite, DCA, which is now considered a marker of occupational exposure (Vitelli et al., 2007). In a survey of occupationally acquired diseases in workers in a pesticide plant, 17 of 28 production workers with exposure to propanil and DCA had chloracne, an acne form of dermatosis; however, a contaminant tetrachlorazobenzene in propanil and DCA was a likely agent causing the chloracne (Morse et al., 1979). Collectively, the data from non-occupational exposure indicate no significant health concern or effect on immune function in contrast to occupational exposure, accidental, or self-poisoning cases.

Concentration, distribution, and pharmacokinetics of propanil metabolism were evaluated using radiolabeled carbon conjugated to propanil in murine blood, liver and spleen to reconcile higher doses used in the majority of experimental studies with lower 
doses typical for environmental exposure (Schafer et al., 2018) using high sensitivity of accelerator mass spectrometry (AMS). The low dose, $854 \mathrm{pg} / \mathrm{g}$ of $\left[{ }^{14} \mathrm{C}\right]-$ propanil per body weight was used to estimate non-occupational exposure, while the high-dose, a mixture of $200 \mu \mathrm{g} / \mathrm{g}\left[{ }^{12} \mathrm{C}\right]-$ propanil and $854 \mathrm{pg} / \mathrm{g}$ of $\left[{ }^{14} \mathrm{C}\right]$-propanil, mimicked occupational, accidental or self-ingestion scenarios. The low doses appeared to be metabolized within an hour, and almost all disappeared within 12 hours. Concentrations decreased in the liver faster than in the blood and the spleen. The response likely reflects the presence of the liver's catabolizing enzymes, which are absent in the blood and the spleen. In contrast, the high dose demonstrated a later peak and much longer duration of higher concentrations of propanil in all three tissues indicative of saturation, and detoxification could not be accomplished within the 12 hour time point (Schafer et al., 2018). These data gauge exposure and prevailing concentrations of propanil (and possibly its metabolites) in organs relevant to the toxicology of propanil and are a valuable tool for future toxicological studies.

\section{Effect of propanil on innate immunity}

The innate immune system ensures the defense of the organism against exogenous pathogens using physical protection in the form of skin and mucosal tissues as well as multiple cell types equipped with phagocytic, chemical, and killing machinery to eliminate invading pathogens. Besides the elimination of pathogens, cells of the innate immune system also capture and introduce the pathogen to cells of the adaptive immune system. The innate immune system includes monocytes, macrophages, polymorphonuclear neutrophils (PMN), and natural killer (NK) cells. For example, when 
whole blood is incubated with HKSP, cytokine production (TNF, IL-6, IL-10, IFN, IL-12, and IL-12p70) from the innate immune cells increases in a time-dependent manner from 4 to 24 hours after exposure (Schultz et al., 1998). Those cytokines are proinflammatory cytokines and activate the innate and adaptive immune systems to help clear the foreign bacteria from the host. If propanil affects the innate immune system, then both the elimination of pathogen and initiation of the adaptive immune response may be compromised. NK cells have antimicrobial cytotoxic mechanisms and work by secreting cytokines. Propanil $(50,100$, or $200 \mathrm{mg} / \mathrm{kg})$ and DCA decreased in a doseresponse pattern on NK lytic activity on day 7 in mice (Barnett et al., 1992). Also, an acute suppressive effect on NK cell activity was reported as early as 12 hours after propanil (Pruett et al., 2000).

A case-control study was conducted in Arkansas, in which the blood samples were collected from 53 people living on 12 farms within 100 yards of rice fields, and their measurements were compared to 55 individuals at 15 farms with crops other than rice (McClure et al., 2001). The immune assessment included a white blood cell count and peripheral blood mononuclear cell (PBMCs) functional assay, such as mitogeninduced cell proliferation, mitogen-induced cytokine production, and cytotoxic PBMC activity (McClure et al., 2001) over two years and three seasons (before, 5-7 days after and post-propanil-spraying season). A comparison of immune function between propanil exposed and control families showed no significant differences in most of the variables and functions, except the percent of natural killer cells in youth living at rice farms were significantly lower (McClure et al., 2001). 
In spleen cells that were exposed to propanil (200 mg/kg), IL-2, IL-6, IFN- $\gamma$, and GM-CSF production decreased after being activated by ConA (a nonspecific mitogen) (Zhao et al., 1998). TNF production in THP-1 cells (human monocytic cell line derived from an acute monocytic leukemia patient) was suppressed at 6,12 , and 24 hours at different doses of propanil $(25,50$, and $100 \mu \mathrm{M})$ (Ustyugova et al., 2007).

In macrophages collected from mice treated with propanil $(200 \mathrm{mg} / \mathrm{kg}$, i.p.) had a reduction in TNF- $\alpha$ over time from 3 to 72 hours (Xie et al., 1997). Intracellular pathways and mechanisms of propanil action in macrophages have been examined. Many extracellular inflammatory signals, bacterial cell wall components, like lipopolysaccharide (LPS), peptidoglycan polysaccharide, growth factors, and cytokines initiate signal transduction and intracellularly converge in the activation of transcription factor Nuclear Factor Kappa B (NF-kB). Activated NF-kB translocates into the nucleus and upon binding to promoter regions, initiates transcription of genes involved in cytokines synthesis. TNF $\alpha$ depends on the NF-kB activation and translocation into the nucleus. In-vitro experiments conducted in macrophage cell line IC-21 stimulated with LPS found reduced NF-KB binding as a result of propanil treatment, measured by confocal microscopy and Western blot (Frost et al., 2001).

In summary, both ex-vivo murine spleen cells within 24 hours in mice and in-vitro cell culture, propanil modified the inflammatory response. 


\section{Propanil effects on primary and secondary lymphoid organs and cellularity}

The bone marrow is where the B-cells develop from the progenitor cells and where they mature. The spleen is a site for the production of antibodies against pathogens by B-cells. The number of murine pre-B-cells in bone marrow decreased to $50 \%$ of control 7 days after 50 mg/kg i.p. propanil (de la Rosa et al., 2003). However, the number of circulating follicular B-cells was not affected after propanil (Salazar et al., 2005). To summarize, the developing $T$ and immature $B$-cells in bone marrow were affected by propanil, but that did not translate to measurable changes in $\mathrm{T}$ and $\mathrm{B}$-cell numbers in circulation.

Researchers have examined bone marrow and thymus, the primary lymphoid organs, and their cellular populations as possible targets of propanil. Female C57BI/6 mice were treated with $0,50,100$, or $200 \mathrm{mg}$ of propanil/kg of body weight on day 0 and bone marrow (BM) collected on day 7 (Blyler et al., 1994). The number of leukocytes from the BM was determined, and cells were cultured for 6 days, after which the recombinant colony-stimulating factor ( $\mathrm{rCSF}$ ) induced colony formation was measured. Various stem cell types and stages of hemopoiesis were enumerated using their respective growth factors and cytokines. Formation of a colony of pluripotent stem cells that are induced to differentiate in the presence of interleukin (IL)- 3 (CFU-IL-3) was inhibited by each dose of propanil (50,100 and $200 \mathrm{mg} / \mathrm{kg}$ ). The next developmental stage, myeloid stem cell (CFU-S) function, was measured by transferring bone marrow cells from propanil-injected mice $(200 \mathrm{mg} / \mathrm{kg})$ to irradiated syngeneic recipient mice. After 12 days, the splenic foci were enumerated. The number of CFU-S (100 \pm 15 
colonies per million cells) in propanil-treated mice was about a quarter of the number of CFU-S in control mice (390 \pm 30 colonies per million cells). CFU-S mature either into the myeloid lineage, starting with granulocyte-macrophage-progenitor cells (GM) or into the erythroid lineage, depending on growth factor and cytokine. Propanil doses of 50 $\mathrm{mg} / \mathrm{kg}$ and higher reduced the number of CFU-GM colonies to about half of the control mice. However, the more differentiated cells of the myeloid lineage, such as macrophage progenitor cells (CFU-M) and granulocyte progenitor cells (CFU-G), were not affected by propanil.

Similarly, the earlier progenitor of erythroid cell lineage, the erythroid burstforming unit (BFU-E) colony number was decreased by propanil, while the later developmental stage, the erythroid colony-forming unit (CFU-E) was not affected. Results might represent selective toxicity of propanil, also suggested by a study where natural killer cell function was significantly decreased while the cytotoxic T-cell function was not affected by propanil (Barnett et al., 1992). The effect of propanil and DCA on human and murine erythroid progenitor lineage BFU-E and CFU-E as well as on the granulocyte/macrophage progenitors (CFU-GM) was carried out in an interspecies comparison of in-vitro and ex-vivo toxicity, respectively (Malerba, 2002). Human mononucleated cord blood cells and BM cells obtained from CD-1 male mice were each cultured for one to two weeks in their required media with addition of propanil or DCA at $10,20,50,100,200,500$ and $1000 \mu \mathrm{M}$ for 3 and 10 days (BFU-E and CFU-E cultures) or for 7 days (CFU-GM cultures). The concentration of propanil or DCA that inhibited $50 \%$ of the growth of the cells $\left(\mathrm{IC}_{50}\right)$ was much lower in murine erythroid progenitors $(<70 \mu \mathrm{M})$ than the granulocyte-macrophage progenitors $(170 \mu \mathrm{M})$, showing the erythroid 
progenitors were about 2.5 to 13-times more sensitive than GM progenitors. DCA was a more potent inhibitor of erythrocyte progenitors than the parent compound. Human cord blood cells, however, were not nearly as sensitive to propanil or DCA as murine progenitors, with average $\mathrm{IC}_{50}$ between $200-450 \mu \mathrm{M}$ for propanil and $>500 \mu \mathrm{M}$ for $\mathrm{DCA}$ on erythroid progenitors and $>500 \mu \mathrm{M}$ of either propanil or DCA on GM progenitors. The human erythroid progenitors were more sensitive to propanil than to DCA. In both species, the erythroid progenitors were more susceptible to propanil or DCA than the granulocyte/macrophage progenitors, which can relate to the susceptibility of red blood cells to propanil and DCA in (anemia) and hemoglobin modifications (methemoglobinemia), described in both species (Singleton and Murphy, 1973; McMillan et al., 1991; Roberts et al., 2009).

The thymus is a lymphoid organ where the development and maturation of Tcells occur. T-cells perform many functions in the support and regulation of the humoral immune response and work closely with B-cells, responsible for the production and secretion of antibodies. CD4 ${ }^{+} \mathrm{T}$-cells are mainly involved in activation and regulation of the humoral immune response and cell-mediated immune responses, while $\mathrm{CD}^{+} \mathrm{T}-$ cells mainly destroy infected or transformed cells as cytotoxic T lymphocytes (Owen et al., 2013). T-regulatory and suppressor cells operate in a variety of ways to control the adaptive immune response. Weight and thymocyte populations were examined upon i.p. propanil injection using 100 - 400 mg/kg (Barnett and Gandy, 1989; Cuff et al., 1996; de la Rosa et al., 2005). Evidence from multiple experiments demonstrated a marked decrease in thymic weight, decreased thymus to body weight, and thymic atrophy characterized by a decreased number of immature, double-positive, $\mathrm{CD} 4^{+} \mathrm{CD} 8^{+} \mathrm{T}$-cells 
on days 2 to 4 after propanil injection. By day 7 , the cells and size of thymus begin to recover, preceded by the proliferation of $\mathrm{CD} 4^{+} \mathrm{CD} 8^{+} \mathrm{T}$-cells, and by day 14 , both cellularity and thymus size completely recovered (Cuff et al., 1996). Corticosterone, which was found negatively correlated with the number of double-positive T-cells in a propanil-dose-dependent manner, is the primary mechanism by which propanil induces thymic atrophy is attributed to (Cuff et al., 1996; de la Rosa et al., 2005). Acute i.p. propanil exposure spiked corticosterone concentration in the serum of C57BI/6 mice almost 10-times control levels, peaked at one hour after injection (de la Rosa et al., 2005), and returned to normal levels by 12 hours. Collectively, data from in vivo experiments examining both bone marrow and thymus, demonstrate the sensitivity of these tissues to propanil.

T-cells also reside in the secondary immune organs, such as the spleen and lymph nodes. Various in vivo models, mostly involving the intraperitoneal injection of propanil in mice, as well as in vitro systems utilizing T-cell lymphoma cell lines (Jurkat, EL-4), were utilized to study if propanil affects T-cell number and function. At the highest propanil dose $(400 \mathrm{mg} / \mathrm{kg})$, a decrease in mixed lymphocyte reactions (MLR), characterizing decreased $\mathrm{CD} 4^{+}$function in addition to ex vivo proliferation of splenocytes were observed following stimulation with the T-cell mitogen concanavalin A (ConA) (Barnett and Gandy, 1989).

A lower dose, $200 \mathrm{mg} / \mathrm{kg}$, stimulated a decrease in interleukin-2 (IL-2) and IL-6 production, suggesting the functionality of T-cells was affected by propanil. In vitro studies led to similar results. IL-2 cytokine production by EL-4 cells (human Tlymphoma), stimulated with phorbol 12-myristate 13-acetate (PMA), a mitogen, 
decreased in propanil (20 mM)-treated cells (Zhao et al., 1999). Stimulation of T-cells via the T-cell receptor leads to the secretion of IL-2 and cell proliferation. Transcription of the IL-2 gene decreased to about $50 \%$ of control levels in the presence of propanil, and IL-2 mRNA message stability decreased (Zhao et al., 1999). The human IL-2 gene has a complex promoter region involving multiple transcription factors, including activating protein-1 (AP-1). Utilizing Jurkat cells (human T-lymphoma), stimulated with PMA and ionophore A23187 (lo), IL-2 mRNA decreased due to propanil (Brundage, 2004). The PMA and lo mimic the natural two-signal activation of T-cells, one via the Tcell receptor, second through the co-stimulatory molecule CD28. Also, propanil-treated Jurkat cells had decreased DNA-AP-1 binding activity (Brundage, 2004). Influx in extracellular calcium $\left(\mathrm{Ca}^{+}\right)$, following internal $\mathrm{Ca}^{+}$depletion, is important for optimal Tcell activation. Further work with Jurkat cells, as well as with primary T-cells from mouse spleen- stimulated with anti-CD3 antibodies and propanil demonstrated that intracellular calcium concentrations decreased in a propanil-dose-dependent pattern (Lewis et al., 2008). Also, a transcription factor involved in IL-2 signaling, Nuclear Factor of Activated T-cells (NFAT), decreased to $60 \%$ of controls in propanil-treated and CD3- stimulated Jurkat cells (Lewis et al., 2008). A similar decrease of IL-2 and NFAT in T-cells was also observed with propanil metabolites, DCA, $6 \mathrm{OH}-\mathrm{DCA}$, and NOH-DCA in a doseresponse model (Lewis et al., 2013). The results of the in-vitro studies with EL-4 (Zhao et al., 1999) and Jurkat cells (Brundage, 2004; Lewis et al., 2008) suggest the signal transduction pathway and transcription factor important in IL-2 transcription being adversely affected by propanil treatment. Collectively, decreased thymus size, via increased glucocorticoids, decreased percentage of double-positive $\left(C D 4^{+}, C D 8^{+}\right)$ 
immature T-cells, and reduction in IL-2 cytokine production are the main adverse effects in the thymus and T-cell function in the spleen.

Numerous studies found a significant increase in spleen weight 7 days after propanil injection, referred to as splenomegaly. The cellular examination of the spleen revealed a substantial increase in the number of leukocytes (leukocytosis). The metabolism of propanil to DCA and its metabolites could result in leukocytosis after propanil or DCA. Alternatively, the propanil could have a direct mitogenic effect, or leukocytosis could be a consequence of methemoglobinemia (Barnett et al., 1992).

Bacterial challenges with common pathogens were utilized to evaluate if propanil suppressed the immune system. Propanil administered to C57BI/6 mice together with Listeria monocytogenes (L. monocytogenes) decreased the ex-vivo secretion of interferon (INF)- $\gamma$ but did not change the in vivo concentration of various inflammatory cytokines (Watson et al., 2000). Another model examining antibody response to heatkilled Streptococcus pneumoniae (S. pneumoniae) injected i.p. to C57BI/6 mice concomitantly with propanil was utilized (Salazar et al., 2005). In the United States, four million estimated cases of bacterial pneumonia occur every year (Schultz et al., 1998). S. pneumoniae, a gram-positive bacterium, is the most commonly identified pathogen in community-acquired pneumonia. Heat-killed S. pneumoniae (HKSP), inactivated by heating to $60^{\circ} \mathrm{C}$ for one hour (Salazar et al., 2005), was used as an immune challenge to study the response of mice to propanil. The cell wall of the S. pneumoniae contains antigens that can elicit two kinds of responses, classified as T-independent (TI-2) and Tdependent (TD) (Wu et al., 1999, 2000). Polysaccharide phosphorylcholine (PC) is an S. pneumoniae antigen that usually elicits TI-2 response, while pneumococcal surface 
protein A (PspA) is a TD kind of antigen. The main finding in studies of HKSP given as an immunogen with the propanil, as the immune modulator, was the spleen of propaniltreated mice had a four-fold increase in PC-specific (but not PspA-specific) antibodysecreting cells (ASC) (B cells) at day 5 after exposure (Salazar et al., 2005). When mice were given only HKSP, there was not a marked increase in ASC as with HKSP and 50 or $150 \mathrm{mg} / \mathrm{kg}$ propanil. Propanil further increased the PC-specific ASC in the spleen on day 7 , followed by a gradual decrease to normal by day 14 (Salazar et al., 2005).

However, this increase in ASC depended on the presence of ovaries in female mice, as evidenced by the loss of the ASC increase in ovariectomized mice (Salazar et al., 2006).

Collectively, antibody response to HKSP was increased by propanil, but the increased response in female mice depends on the intact hypothalamic-pituitarygonadal axis, further discussed in the next section. The requirement of ovaries or HPG axis in amplifying the humoral immune response and function of corticosterone on immature T-cells and B-cells in the bone marrow and thymus highlight potential interactions of endocrine and immune systems. Before the discussion of the existing evidence of interactions of reproductive and immune function, mostly in mice, a summary of the main murine reproductive functions and hormones is in place.

\section{Reproductive Hormones}

Rodents are polyestrous species meaning that they have multiple and regular estrous cycles during the year. While the wild mice are seasonal polyestrous species and breeding season is mostly in spring and summer, the inbred mice, like C57BI/6J breed year-round. However, A/J mice, which also breed in laboratory conditions, have 
more offspring in spring and summer months than in the fall and winter (Schile, Jackson Laboratory). The estrous cycle in mice on average is four days long, with each day being a different phase in the estrous cycle: proestrus, estrus, metestrus, and diestrus. Proestrus and estrus are part of the follicular phase when follicles are growing and maturing and start to secrete estradiol. The estrous stage includes the ovulation, release of an ovum or egg, or multiple eggs in some species, from the follicle and ovary, into the oviduct. Mono-ovulatory species, like humans, normally ovulate one follicle per estrous cycle; polyestrous species, like mice, rats, pigs, and cats, ovulate several follicles in one estrous cycle (European Society of Human Reproduction and Embryology, ESHRE, Capri Workshop Group, 2003). Metestrus and diestrus are part of the luteal phase, covering the time from after ovulation until the corpora lutea $(\mathrm{CL})$ regress, which is known as luteolysis. The primary hormone during the luteal phase is progesterone that is secreted by the $\mathrm{CL}$ (Senger, 2012). The CL is a transient endocrine gland that forms by remodeling of the empty, ovum-free, post-ovulatory follicle. The former theca and granulosa cells in the ovulatory follicle get re-purposed into small and large luteal cells. Hormonally, the production of estrogen is turned off at ovulation, and steroidogenic function is switched to progesterone. Overview of steroidogenesis from cholesterol, including the substrates and enzymes, is listed in Figure 2. 


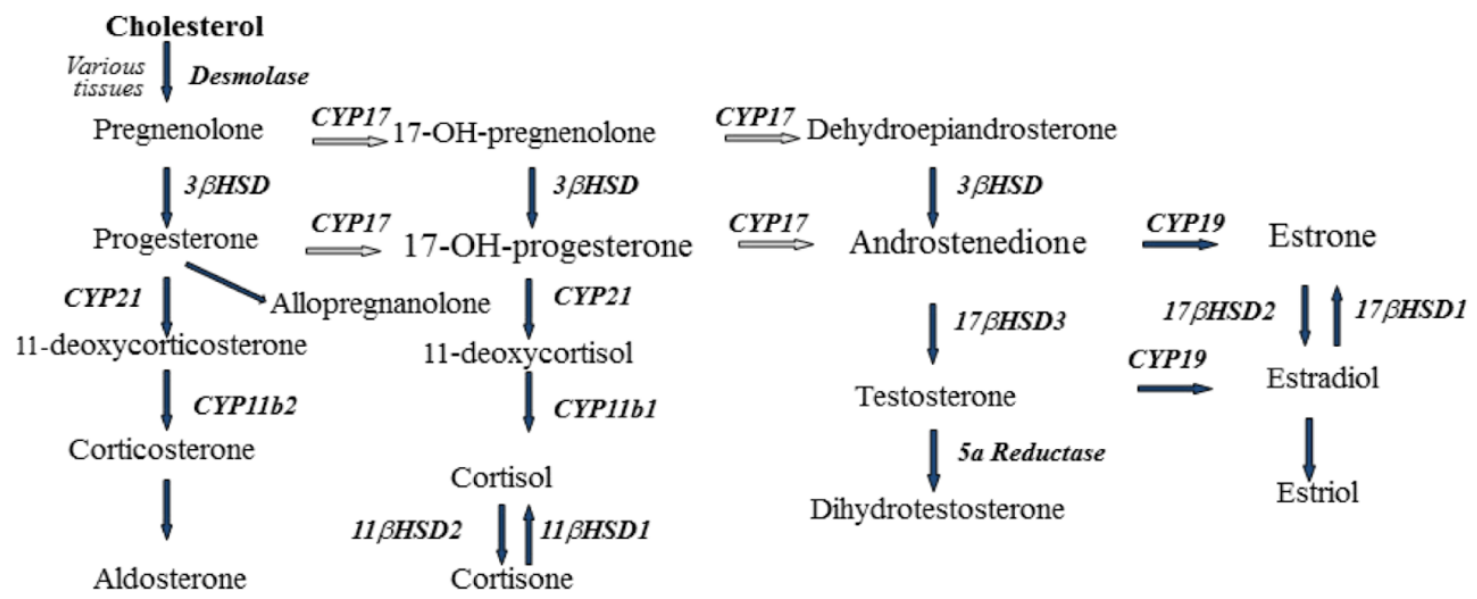

Figure 2. Steroid Synthesis Pathway (Moller and Backstrom, 2016).

The master hormone, gonadotropin-releasing hormone $(\mathrm{GnRH})$, governing the regular cyclical changes in the ovaries, is secreted from the hypothalamus.

Hypothalamic-pituitary-gonadal (HPG) axis is a conduit of reproductive hormones utilizing circulation and second messenger signaling in target tissues. $\mathrm{GnRH}$ is needed to start the follicular phase of an estrous cycle. $\mathrm{GnRH}$ is produced in the hypothalamus and transported via neurons and specialized blood portal plexus to bind to $\mathrm{GnRH}$ receptors ( $\mathrm{GnRHR}$ ) on gonadotropin cells in the pituitary gland. Once $\mathrm{GnRH}$ binds to the receptor, the gonadotropin cells release luteinizing hormone (LH) and folliclestimulating hormone (FSH). The gonadotropins are transported in blood and bind to their respective receptors on follicles of specific sizes in the ovary. LH binds to receptors on theca interna cells to start producing testosterone, which diffuses across the membrane to granulosa cells where FSH binds to its receptor to mediate the production of aromatase (CYP19A1). Aromatase converts testosterone into estradiol (Figure 2), which attaches to transport proteins in capillaries to be delivered to the reproductive tract, pituitary, hypothalamus, and other organs. The process of estrogen production in 
the follicle is referred to as The Two-Cell-Two Gonadotropin Model, as it involves the two follicular cell types (theca and granulosa) and two gonadotropins ( $\mathrm{LH}$ and $\mathrm{FSH}$ ) (Senger, 2012). Estradiol acts via positive and negative feedback on the hypothalamus, depending on the stage of the cycle (Senger, 2012). During the follicular stage, estradiol $\left(E_{2}\right)$ from growing follicles has positive feedback on the surge center in the hypothalamus, stimulating the preovulatory surge of $\mathrm{GnRH}$. At the same time, $\mathrm{E}_{2}$ causes inhibition of FSH from the anterior pituitary in a negative feedback fashion. Thus, the ratio of $\mathrm{FSH}$ and $\mathrm{LH}$ changes and $\mathrm{LH}$ increases into the ovulatory surge immediately before ovulation (Senger, 2012). The major effects of estrogen in the reproductive tract are increased blood flow, swelling, change in tissue electrical conductivity, increased number of leukocytes, an increase in smooth muscle motility and initiation of uterine growth (Sanger, 2012).

In addition to $E_{2}$, granulosa cells of follicles in the ovary generate activin and inhibin, the glycoprotein hormones that activate or inhibit, respectively, the FSH secretion by the pituitary. During the luteal phase, progesterone from the CL has many functions. It induces negative feedback on the hypothalamic $\mathrm{GnRH}$ to allow for time without ovulation, it induces growth of mammary gland and growth of uterine lining with uterine glandular secretion, while at the same time prevents contractions of smooth muscle cells in the myometrium. Another hormone involved in the estrous cycle is oxytocin, a neuropeptide mostly produced by the hypothalamus and stored in the posterior pituitary. Oxytocin is also synthesized by the CL (Sanger, 2012). The target tissue of oxytocin is uterine myometrium, endometrium, and mammary gland. It is responsible for uterine motility, promotion of uterine prostaglandin $F_{2 \alpha}\left(P_{G} F_{2 \alpha}\right)$, and milk 
ejection. Another hormone important in rodent reproduction is prolactin, a protein produced in the anterior lobe of the pituitary gland. The known target tissues are mammary cells, CL (in rat and mouse), and the brain (Sanger, 2012). PGF ${ }_{2 \alpha}$, a C-20 fatty acid, is secreted by uterine myometrium and targets the CL for luteolysis at the end of the luteal phase, promotes uterine tone and contractions and is also involved in ovulation. Hormone counteracting $\mathrm{PGF}_{2 \alpha}$ actions is prostaglandin $\mathrm{E}_{2}\left(\mathrm{PGE}_{2}\right)$, secreted by ovaries, uterus, and embryonic membranes.

$\mathrm{GnRH}$ function is often tested by utilizing a $\mathrm{GnRH}$ antagonist. Antide is a $\mathrm{GnRH}$ antagonist that binds to the GnRHR to block $\mathrm{GnRH}$ from binding. Antide injected every 12 hours for 48 hours into female rats increased ovarian weight and number of preovulatory follicles (Parborell et al., 2005). They also found that antide inhibits cell death in preovulatory follicles by decreasing the protein BAX translocation to the mitochondria (Parborell et al., 2005).

Collectively, hormones that are important in mice reproduction include $\mathrm{GnRH}$, $\mathrm{FSH}, \mathrm{LH}$, prolactin, progesterone, testosterone, $\mathrm{E}_{2}$, activin, inhibin, oxytocin, $\mathrm{PGF}_{2 \alpha}$, and $\mathrm{PGE}_{2}$. However, these hormones are also involved in immune function and regulation. For example, prolactin stimulates T-lymphocytes (Bachelot and Binart, 2007). Dopamine from the brain inhibits the synthesis of prolactin (Ben-Jonathan and Hnasko, 2001). Prolactin has been suggested to enhance mature B cell function by increasing IgG and IgM antibody production (Lahat et al., 1993; Yu-Lee, 1997). Prolactin regulates the immune system through the transcription factor IRF-1, which can lead to the proliferation of $\mathrm{T}$ cells, differentiation of $\mathrm{B}$ cells, differentiation of $\mathrm{CD} 8^{+} \mathrm{T}$ cells, antigen presentation, and macrophage activation (Yu-Lee, 1997; Book McAlexander and Yu- 
Lee, 2001). Prolactin is required for T helper cells to proliferate when the proliferation is IL-2 driven (Clevenger et al., 1990). An in vivo study demonstrated that rodents become immunosuppressed if there was a decrease in circulating prolactin levels (Hartmann et al., 1989). Healthy humans given recombinant human prolactin showed a decrease in pulsatile $\mathrm{LH}$ leading to the conclusion that high prolactin levels suppress $\mathrm{GnRH}$ secretion (Page-Wilson et al., 2006).

Estrogens play a vital role in immune function. In chronic exposure, $E_{2}$ has been observed to increase the number of immunoglobulin-producing cells in the blood, while decreasing the number of splenic B-cells (Verthelyi and Ahmed, 1998). A study confirmed that estrogen receptor signaling regulates innate immune cells such as macrophages and monocytes (Straub, 2007). When mice are ovariectomized (OVXed), they have an increase in leukocytes, mostly neutrophils, and lymphocytes in the blood (Stubelius et al., 2017). They determined that sex steroids and especially estrogen can regulate inflammation, specifically during ovulation.

Progesterone also is a primary immunomodulatory sex hormone. Previous research has shown that progesterone can induce $\mathrm{TH} 2$ cytokine production. An in vitro study confirmed that when human cloned T cells from patients with multiple sclerosis were cultured with progesterone, the cells produced IL-4 and suppressed inflammatory cytokine production that included IL-10, TGF- $\beta$, INF- $\gamma$, and TNF- $\alpha \beta$ (Correale et al., 1998).

Reproductive hormones play an important role in maintaining the estrous cycle, fertility as well as helping the immune system. Each hormone acts on the immune 
system in specific ways: estrogen is proinflammatory, while progesterone can be antiinflammatory. Overall, almost all the reproductive hormones discussed also affect immune function, specifically on B-cells and T-cells.

\section{Effects of propanil on the endocrine, including reproductive, system}

Propanil was termed an endocrine disruptor (Kojima et al., 2004; Salazar et al., 2006). Propanil at 75,100 , and $150 \mathrm{mg} / \mathrm{kg}$ increased corticosterone over several hours in mice and simultaneously caused a dose-responsive decrease in thymocyte numbers (Pruett et al., 2000). Propanil decreased the weight of the thymus of female mice exposed to an injection (i.p.) of propanil at $200 \mathrm{mg} / \mathrm{kg}$, and an about 10 -fold increase in corticosterone $(\mathrm{ng} / \mathrm{ml})$ was observed at one-hour post-exposure (de la Rosa et al., 2005). Adrenalectomy partially abrogated the decrease in immature T-cells in the thymus after propanil (Cuff et al., 1996), providing the evidence of corticosteroids from the adrenal gland mediating the propanil effect on decreased thymus weight and cellularity. European eels treated with propanil for 72 hours had an increase in cortisol from 24 hours through hour 144 (Sancho et al., 2017). Collectively, the evidence suggests propanil induces the physiological stress, represented by increased corticosteroids, as an endpoint of the hypothalamic-pituitary-adrenal axis. Elevated corticosteroids may then affect the function of immune cells in many different ways. For example, short-term stress may lead to induced immuno-protective functions or immuno-pathology. Chronic or long-term stress may lead to induced immunopathology as well as immuno-suppression (reviewed by Dhabhar, 2014). 
The connection between the effect of propanil on the spleen and its increase of S. pneumoniae - specific ASC being conditional on the presence of ovaries or intact HPG axis in female mice was examined and discussed (Salazar et al., 2006, 2008). Propanil, given to mice with HKSP, caused a three to six-fold increase in the number of PC- specific antibody-secreting cells (ASC) on day seven post-exposure, compared to only HKSP group (Salazar et al., 2005, 2006). Both male and female mice had increases; however, in females, the increase was revoked by ovariectomy (OVX), but not by orchidectomy in males (Salazar et al., 2006). Because of the known effects of steroids on the immune system, experiments testing specific steroid hormones produced by ovaries were designed to examine the interaction with propanil on the PCspecific, ASC increase (Salazar et al., 2006; Holásková et al., 2015). Utilizing the "remove and replace" model, exogenous estradiol given to OVX mice did not restore the effect of the propanil-mediated enhancement on PC-specific ASC increases. Estrogen receptor alpha antagonist, ICI 182,780, did not prevent the PC-specific, ASC increase (Salazar et al., 2006), demonstrating the HKSP/PC-specific ASC increase may be happening independently of the estrogen receptor. This was supported further by the findings propanil did not bind to either ER- $\alpha$ or ER- $\beta$ at day 7 in female mice (Kojima et al., 2004, Salazar et al., 2006).

Similarly, subcutaneous treatment with progesterone antagonist RU486, given two hours before propanil, 12 hours after propanil and every 24 hours during the duration of the experiment, did not prevent the PC-specific ASC increase (Salazar et al., 2006). This was evidence that blocking endogenous progesterone did not block the PCspecific ASC rise in the spleen. Treatment of mice with testosterone propionate, given 
to female pups peri- and postnatally to "masculinize" the spleen response, altered neither the rise in ASC in propanil-treated, HKSP-challenged female nor OVXed mice (Holásková et al., 2015). The masculinization of reproductive function was evident by highly irregular estrous cycles determined by vaginal lavage, but the masculinization of the PC-specific ASC response did not occur. The evidence suggested the ovarianspleen relationship in HKSP/propanil - treated females occurs independently of testosterone as well. Removal of endogenous testosterone source by orchidectomy did not affect the PC-specific ASC response in the spleen of male mice (Salazar et al., 2006).

A weak antiandrogenic function of propanil was demonstrated using the androgen receptor assay, and propanil was shown to inhibit transcriptional activity by dihydrotestosterone (DHT) in mouse hepatoma Hepa1c1c7 cells (Kojima et al., 2004). $\mathrm{DHT}$ is the most active form of testosterone; therefore, they hypothesized propanil inhibits the transcriptional activity of DHT by blocking the androgen receptor, which is a nuclear receptor. Their data provided evidence that propanil may show antiandrogenic activity in vitro. Contrasting were the findings with propanil metabolite DCA, using ex vivo androgen-sensitive, calf uterus cytosol assay, where DCA misplaced only a minuscule fraction of $\left[{ }^{3} \mathrm{H}\right]$ dihydrotestosterone $(\mathrm{DHT})$ on the androgen receptor, $6.2 \mathrm{x}$ $10^{-5}$ (Bauer et al., 1998). In summary, the experimental evidence eliminated the main ovarian steroids, such as estrogen, progesterone, and testosterone, as possible mediators of the sexually dimorphic PC-specific ASC response.

However, an injection of antide, an antagonist of gonadotropin-releasing hormone $(\mathrm{GnRH})$, into female mice attenuated the increase ASC (Salazar et al., 2006) 
at day seven after exposure to propanil, similar to the effect to OVX in mice. Therefore, propanil may interact with the hypothalamus-pituitary-gonadal axis (HPG axis) to increase ASC. Known target tissue of GnRH is the pituitary gland (Senger, 2012); nonetheless, $\mathrm{GnRH}$ receptors are present on other tissue, for example, spleen (Jacobson et al., 1998) and ovary (Torrealday et al., 2013). In thymus and spleen, $\mathrm{GnRH}$ receptors (mRNA) are detected in a pattern similar to the pituitary gland, suggesting the estrous cycles and feedback mechanisms of steroid and nonsteroidal hormones might be affecting immune function as well (Jacobson et al., 1998). DBA/2 mice had an increase in GnRHR mRNA in the evening of proestrus when represented with an autoradiograph of competitive RT-PCR analysis of GnRHR in the spleen and thymus while only showed an increase in GnRHR during estrus in the thymus (Jacobson et al., 1998). Mice that were in proestrus or estrus showed to have a significant increase in $\mathrm{GnRH}$ in both the thymus and the spleen (Jacobson et al., 1998). $\mathrm{GnRH}$ is barely detectable in adult circulation but is very high during fetal development. It was demonstrated that $\mathrm{GnRH}$ signaling is involved in thymic development (Melnikova et al., 2019).

\section{Propanil exposure during pregnancy}

There are a few reports on the effects of propanil on reproductive functions or hormones during pregnancy in mammals. In a chronic oral toxicity study (Ambrose et al., 1972), three generations of albino rats had $0,100,300$ or $1,000 \mathrm{ppm}$ of propanil incorporated into their diet before mating and during pregnancy, parturition, lactation, and various gestational and histopathological indexes, including fetal autopsies, were examined. No deleterious effects on any reproduction performance were observed in 
any of the diet groups of propanil-treated rats studied. (Ambrose et al., 1972). However, at a higher dose $(1,600 \mathrm{ppm})$ and chronic oral exposure of rats over 2 years, an increase in testes organ-to body weight ratio in males, as well as increase spleen size of male and female rats, were noticed. In the same report, subchronic oral toxicity, feeding 10,000 ppm propanil to rats for three months resulted in increased testes, heart, and spleen weight in males (Ambrose et al., 1972).

To determine pregnancy outcome after being exposed to propanil, researchers injected female rats with three different doses on different days of pregnancy. Rats were orally given propanil at $175 \mathrm{mg} / \mathrm{kg}$ per day and $350 \mathrm{mg} / \mathrm{kg}$ per day on days one through three of pregnancy had a decrease in the number of implants and the number of pups born and an increase in pre-implantation loss (Ratnasooriya and Perera, 1997). A very similar pattern of embryonic loss occurred when the higher dose ( $350 \mathrm{mg} / \mathrm{kg}$ per day) of propanil was given to rats in the first two days of pregnancy (Ratnasooriya and Perera, 1997). Propanil needed to be administered at least two consecutive days at a dose of $350 \mathrm{mg} / \mathrm{kg}$ to see a response in pregnancy variables. Three different mechanisms could explain the embryonic losses: Firstly, propanil could have a luteolytic effect on CL and cause functional regression of $\mathrm{CL}$ and the loss of progesterone-production. Decreased size and altered morphology (color) or the rat corpora lutea accompanied preimplantation and post-implantation losses (Ratnasooriya and Perera, 1997). Altered serum estrogen and progesterone balance can prevent implantation (Bonney and Franks, 1990). The second possible mechanism of propanil could be alteration in the speed of embryonic transport mediated by a decrease of estrogen (Kaplan-Kraicer et al., 1995). Estrogen stimulates the motility of the oviduct and propelling the fertilized egg 
towards the uterus. If propanil decreased estradiol, that would reduce the rate of embryonic transport that could lead to an increase in preimplantation loss. However, propanil does not decrease estrogen directly as it does not bind to the estrogen receptor $\alpha$ or $\beta$ (Salazar et al., 2006), making this mechanism unlikely. The indirect mechanism of the effect of propanil on estrogen by modifying the availability of key steroid-synthesis enzymes, like aromatase (a.k.a. CYP19A1, Figure 2) remains an option to be examined. The third possibility could be the interruption in uterine blood supply (Antebi et al., 1991). Lack of oxygen-carrying capacity via methemoglobinemia or decrease in red blood cells due to propanil (McMillan et al., 1990, 1991) could be detrimental to the CLs, developing embryos or post-implantation fetuses. Clinical evidence from deliberate poisoning reported a case of pregnant females losing pregnancies (Eddleston et al., 2002).

Freshwater snails exposed to propanil at a concentration of $10-5 \mathrm{M}$ had reduced egg-maturation and an increase in dead embryos by the end of the twentieth day and overall delayed development of embryos (Kosanke et al., 1988). Propanil affected length, survival, and fecundity of small planktonic crustacean, Daphnia magna, treated in water for 21 days with different doses (Villarroel et al., 2003). They also showed a dose-dependent decrease in days to first brood, the number of young ones per adult, brood size, and the number of broods per adult with the most significant decrease at the highest dose of $0.55 \mathrm{mg} / \mathrm{l}$.

In summary, propanil has adverse effects on pregnancy. The exact mechanism is not defined yet, but steroid synthesis, luteolytic action, or lack of oxygen may be involved. 


\section{The connection between the spleen and ovary}

When ovulatory gonadotropin stimulation occurs in the ovary, it activates an apparent local acute inflammatory response (Espey, 1980). This inflammatory response

during ovulation is similar to the response seen during an infection (Oakley et al., 2011). Leukocytes are involved in three main phases of ovarian function. These functions include loosening of the follicular wall, which allows the follicle to grow and ovulate, tissue repair after the follicle ruptures (ovulation), and lastly, the formation of the CL and its regression after progesterone decreases (Oakley et al., 2011). Leukocytes are recruited from the spleen to the ovary after the release of cytokine from the inflamed tissue around the ovulated follicle (Oakley et al., 2011). Therefore, the authors' suggested the connection between the ovary and spleen during ovulation be called the pituitary-ovarian-splenic axis. They hypothesized that leukocytes carrying specific markers traverse from the spleen and are attracted to chemokines produced by follicles. The leukocytes then move from the capillary into the ovary to increase the number of leukocytes. They suggested that the spleen is a bridge between the immune and reproductive systems by serving as a reservoir for leukocytes needed for ovulation. Collectively, data available on propanil and reproductive function are sparse and inconsistent. Determination of the effect of propanil in the HKSP/propanil murine model on ovaries and ovarian function-related hormones would aid in understanding the interaction of reproductive and immune systems in the face of immune/chemical challenge. 


\section{Summary}

Overall, propanil affects the circulatory, reproductive, endocrine, nervous, and immune systems. Interactions of these systems are evident but not well understood. When studying the connection between the spleen and the female reproductive system, HKSP can be useful for challenging the murine immune system to enhance the impact propanil has on the immune and reproductive target tissues. Steroid synthesis (hormones and enzymes for progesterone, testosterone, and estrogen), neuropeptides (GnRH and oxytocin), glycoproteins (FSH, LH, activin, and inhibin), protein (prolactin) and prostaglandin $\left(\mathrm{PGF}_{2 \alpha}\right.$ and $\mathrm{PGE}_{2}$ ) hormones may all be possibly affected by propanil. Subsequently, the affected hormone(s) may then signal immune cells in the spleen and affect the initial decrease and later increase in the spleen size and the number of HKSP/PC-specific ASC. Therefore, the experiments were designed to determine whether ovarian, systemic, and splenic factors are expressed differentially 24 hours after propanil/HKSP immune/chemical challenge and could indicate early changes that can influence the spleen HKSP/PC-specific ASC numbers in spleen seven days later. Individually, we examined the effect of propanil/HKSP on 1) ovarian genes that are activated or suppressed, 2) effects on systemic hormone concentrations, 3) splenic cell populations, and 4) involvement of $\mathrm{GnRH}$ antagonist in this model of endocrine disruption/immune challenge. 


\section{Chapter 2: Statement of Problem}

A preliminary step in detecting compounds that ovaries secrete used a working model of propanil (200 mg/kg/BW i.p.), vaccine HKSP (Salazar et al., 2005, 2006; Holásková et al., 2015) and microarray data analysis (murine Affimetrics chip, Cleveland Clinic, unpublished, Dr. Schafer). Ovarian mRNA expressions of 106 genes were significantly modified at 24 hours due to propanil. Sixty-four were upregulated, and 42 were downregulated. Top genes upregulated included inflammatory markers, cytokines, and chemokine immune regulators, transcription factors, and adhesion molecules, and are listed with their abbreviation and known ovarian function in parentheses (determined using Ingenuity Pathway Analysis, Qiagen, Hilden, Germany): Serum Amyloid A 3 (SAA3, ovulation), S100 calcium binding protein A8 and A9 (S100A8 and S100A9, both involved in ovulation); chemokine (C-C motif) ligand 7 (CCL7), serpin family A member 3 (SERPINA3); chitinase 3 like 1 (CHI3L1), guanylate cyclase activator 2B (GUCA2B), lipocalin 2 (LCN2), complement factor B (CFB), glycosylation dependent cell adhesion molecule 1 (Glycam 1), vascular cell adhesion molecule 1 (VCAM1), C-X-C motif chemokine ligand 2 (CXCL2), suppressor of cytokine signaling 3 (SOCS3, involved in oocyte maturation and luteolysis), C-C motif chemokine ligand 2 (CCL2, involved in luteolysis), interleukin 18 receptor 1 and intercellular adhesion molecule 1 (ICAM1, follicle rupture, ovulation, luteinization and luteolysis).

Top genes decreased due to propanil in 24 hours in murine ovaries included enzymes involved in steroid synthesis, such as cytochrome P450 family 11 subfamily B member 2 (Cyp 11B2, involved in corticosterone synthesis), dehydrocholesterol 
reductase (DHCR7), cytochrome P450 family 17 subfamily A member 1 (CYP17A1, involved in hydroxy-progesterone conversion from progesterone), ADAM metallopeptidase with thrombospondin type 1 motif 1 (ADAMTS1, involved in ovarian follicle development, ovulation, follicle rupture and luteinization), carbonic anhydrase 3 (CA3), melanocortin 2 receptor accessory protein (MRAP), X-prolyl aminopeptidase (XPNPEP2), complement factor D (CFD), and endothelin 2 (EDN2).

Based on the literature and preliminary analysis of microarray data, there are two aims of the proposed research. The first aim is in light of evidence that the presence of the ovaries is vital for the increase in the number of PC-specific antibody-secreting cells in the spleen on Day 7 (Salazar et al., 2006). Thus, we first determined the acute effect of propanil on the changes in expression of genes in ovaries and oviducts, systemic concentrations of specific reproductive hormones, and splenic weight and cell populations. We hypothesize that ovarian and oviductal genes involved in ovulation, inflammation, steroid hormone synthesis, and tissue remodeling are modified at 24 and 72 hours after propanil/HKSP injections in female mice. We hypothesize that prolactin, progesterone, and estradiol are affected by propanil. Also, even though adaptive immune response (rise in PC-specific-ASCs) cannot be evident in the spleen in such a short time, we expect that the immune cell populations vary in composition and number due to propanil as early as 24 or 72 hours. The experiments testing these hypotheses comprise Trials 1 and 2 .

The second aim is inspired by the fact that an intact HPG axis was necessary for the increase of HKSP/PC-specific antibody-secreting cells response in the spleen on Day 7 (Salazar et al., 2006). We examined the interaction of $\mathrm{GnRH}$ (using a GnRH 
antagonist, antide) and propanil on the expression of genes in the ovaries and oviducts, systemic concentrations of specific reproductive hormones, and splenic weight and cell populations.

We hypothesize that $\mathrm{GnRH}$ is involved in the propanil-mediated effects. Therefore, antide (GnRH antagonist) would interfere with propanil influences on ovarian gene expression, spleen cell populations, and reproductive hormones indicating that an intact HPG axis is necessary for the acute propanil-mediated responses. The experiment testing these hypotheses is Trial 3. 


\section{Chapter 3: Materials and Methods}

Animals. Eighty-four of 6-9 weeks old C57BI/6 female mice (trial 1, $\mathrm{n}=24$; trial 2 , $\mathrm{n}=12$; trial $3, \mathrm{n}=48$ ), weighed 18 to 20 grams (Jackson Laboratory, Bar Harbor, ME), were housed 3-4 per cage at West Virginia University (WVU) vivarium. The mice were on 12 hour-light and dark cycles and provided food and water ad libitum. The mice were acclimated to the WVU vivarium for 5 days before the start of an experiment. All procedures were approved by the WVU Institutional Animal and Care Committee (IACUC \# 1603001079.8).

HKSP preparation. S. pneumoniae strain R36A is an avirulent, nonencapsulated bacterial strain used as an antigen to activate the immune system. The vaccine was prepared as described previously (Wu et al., 1999; Salazar et al., 2005). S. pneumoniae strain R36A was grown to mid-log phase in Todd-Hewitt broth supplemented with $2 \%$ yeast extract (BD Biosciences) at $37^{\circ} \mathrm{C}$. The culture was grown to OD600 of 0.4 , and immediately heat-killed at $60^{\circ} \mathrm{C}$ for $1 \mathrm{~h}$, washed twice in $0.85 \%$ saline and resuspended in saline at $2 \times 10^{8} \mathrm{CFU} / \mathrm{ml}$. Sterility and the number of CFU were confirmed by culture on blood agar plates before the killing, and after, the heatkilled stock was stored at $-80^{\circ} \mathrm{C}$.

HKSP immunization and propanil exposure. The schedule of immunizations and treatments for all three trials are in Figure 3. Mice were treated with $200 \mathrm{mg} / \mathrm{kg}$ propanil (N-10800-500MG, Chem Service, West Chester, PA) dissolved in peanut oil or peanut oil alone (control) and HKSP $\left(2 \times 10^{8} \mathrm{CFU}\right)$ dissolved in PBS. The injections were given intraperitoneally (i.p.) at hour 0 . Mice were monitored throughout the day for signs 
of lethargy until hour 8 (Chow and Murphy, 1975). The mice were euthanized with Euthasol (100 mg/kg, i.p.) (Henry Schein, Inc., Melville, NY) at 24 and 72 hours (Trial 1) or only at $\mathbf{2 4}$ hours (Trial 2 and 3 ) after treatment. Immediately after euthanasia, blood, ovaries, and spleen (Trial 1 and 3) or blood, ovaries, oviducts, and spleen (Trial 2) were collected.

Antide. In trial 3, mice were treated with $60 \mathrm{mg}$ of antide dissolved in $0.9 \%$ propylene glycol or $0.9 \%$ propylene glycol alone (control) every other day for a total of six injections. The injection was given subcutaneously between 1300-1400 hours.

Prolactin, Progesterone, and Estradiol ELISA. Blood was collected by cardiac puncture after euthanasia at 24-hours or 72-hours after treatment. Serum prolactin levels were determined using a mouse/rat prolactin ELISA kit (PR063F-100), mouse/rat estradiol ELISA kit (ES180S-100), and progesterone ELISA kit (PG362S, Calbiotech, Spring Valley, CA). Samples were measured at $450 \mathrm{~nm}$ using an Epoch Microplate Spectrophotometer (BioTek, Winooski, VT). AssayZap (Biosoft, Great Shelford, Cambridge) was used to determine concentrations. 


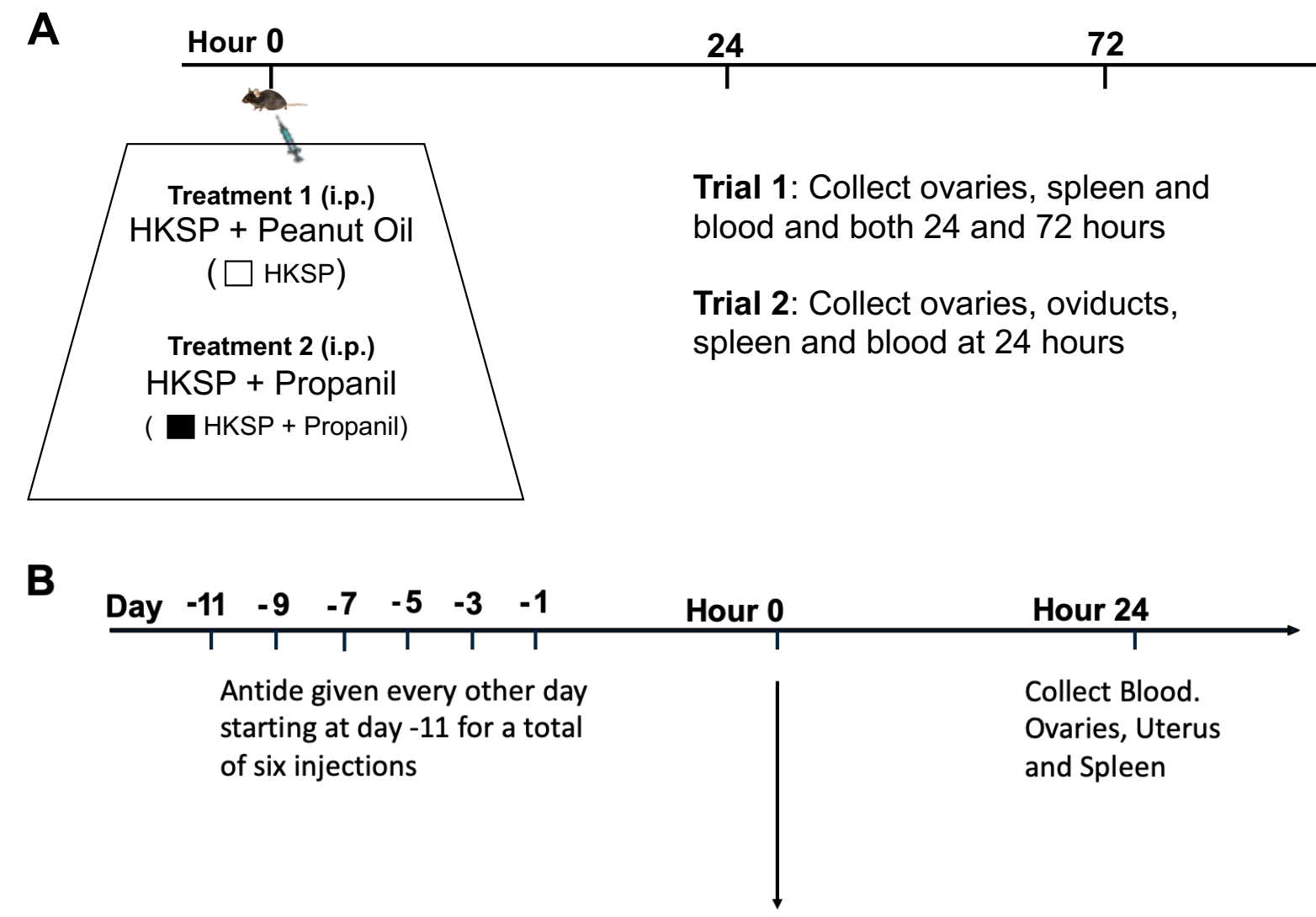

\begin{tabular}{|c|c|c|}
\hline Immunogen & Hormonal Modulator & Immune Modulator \\
\hline \multirow{2}{*}{ Saline (control) } & Propyl. Glycol (control) & \multirow{4}{*}{ Peanut Oil (control) } \\
\hline & Antide & \\
\hline \multirow{2}{*}{ Heat-killed Streptococcus pnumoniae (HKSP) } & Propyl. Glycol (control) & \\
\hline & Antide & \\
\hline \multirow{2}{*}{ Saline (control) } & Propyl. Glycol (control) & \multirow{4}{*}{ Propanil } \\
\hline & Antide & \\
\hline \multirow{2}{*}{ Heat-killed Streptococcus pnumoniae (HKSP) } & Propyl. Glycol (control) & \\
\hline & Antide & \\
\hline
\end{tabular}

Figure 3. Timeline for experimental design. Trial 1 and $2(A)$ and trial $3(B)$.

Splenocyte Isolation and Flow Cytometry. Single-cell suspensions of splenocytes were generated using tissue dissociation through nylon mesh (89000-044, VWR International, Indianapolis, IN) in RPMI-1540 (BioWhiteaker, Walkersville, MD), $10 \%$ heat-inactivated fetal bovine serum (FBS, Hyclone Laboratories, Inc, Logan, UT), 10 mM HEPES (Sigma), 1mM L-glutamine (Gibci, Rockville, MD), 5x10-5 M 2- 
mercaptoethanol (Sigma), $100 \mathrm{U} / \mathrm{ml}$ penicillin (Gibco) and $100 \mathrm{mg} / \mathrm{ml}$ streptomycin (Gibco). Red blood cells were lysed with Tris-buffered ammonium chloride. Cell viability and quantity were enumerated with trypan blue dye exclusion, and splenocytes from individual mice $\left(1 \times 10^{6}\right)$ were stained with fluorochrome-conjugated antibodies: CD4FITC (553729, BD Bioscience, San Jose, CA), CD8- PE (561095), B220- Pacific blue (558108) and CD11b- Alexa Fluor 700 (56-0112-80) for phenotypic analysis using flow cytometry at 24 hours. Staining was performed by adding $1 \times 10^{6}$ cells to individual wells on a 96-well plate and centrifuged for 5 minutes at $1500 \mathrm{rpm}$. The supernatant was removed, and the cells were resuspended in $100 \mu \mathrm{l}$ of flow cytometry buffer (PBS with $1 \%$ FBS and $0.04 \%$ sodium azide). The cells were centrifuged again, and $25 \mu \mathrm{l}$ of the specific antibody was added to each well. The plate with cells was then wrapped in foil and left on ice for 20 minutes. The cells were washed twice with flow cytometry buffer to remove the unbound antibodies. The cells were then fixed with $100 \mu \mathrm{l}$ of paraformaldehyde, wrapped in foil and stored at $4^{\circ} \mathrm{C}$ overnight. Data were acquired using a FACSAria III, employing FACS Diva software version 8.0 (BD Biosciences, USA) and analyzed using FCS Express software version 5 (DeNovo Software, Glendale, CA). A total of 10,000 events were collected and analyzed for each sample, including controls, including individual cell stains and no stain. The percentage of particular cell types detected by flow cytometry multiplied by the total number of cells determined by hemocytometer gave the cell numbers for each mouse.

RNA Extraction and Quantitative Real-time PCR (qRT-PCR). Total RNA was extracted from frozen whole ovaries (Trial 1) or oviductal tissue (Trial 2) using the ENZA Total RNA Kit I (catalog number R6834-01, Omega BIO-TEK, Norcross, GA). After RNA 
extraction, High-Capacity cDNA Reverse Transcription Kit (Applied Biosystems, Foster City, CA, catalog number 4368814) was used to transcribe RNA into cDNA for real-time PCR. Primers used from PrimerBank were purchased from Invitrogen (Table 1). The PCR reactions consisted of $15 \mu \mathrm{L}$ PowerUp SYBR green master mix (Applied Biosystems, Foster City, CA, catalog number A25778,) and $5 \mu \mathrm{L}$ of sample developed during an initial temperature of $50^{\circ} \mathrm{C}$ for 2 minutes then $95^{\circ} \mathrm{C}$ for 2 minutes followed by 40 cycles consisting of melting at $95^{\circ} \mathrm{C}$ for 15 seconds and annealing and extension at $60^{\circ} \mathrm{C}$ for 1 minute using the CFX96 Touch Real-Time PCR Detection System (Bio-Rad, Hercules, CA). CFX Maestro (Bio-Rad, Hercules, CA) software was used to collect the data. Qbase+ (version 3.2, Biogazelle, Zwijnaarde, Belgium) geNorm function was completed to determine the most suitable housekeeping genes from a panel of commonly used housekeeping genes (Hprt1, Gapdh, Actb, 18s, B2m, Hmbs, Ppia, and Sdha). Qbase+ was used to normalize the qRT-PCR data using Hprt1 and Actb as the two housekeeping genes. Qbase+ uses a generalized delta-delta quantification cycle method ( $\Delta \Delta \mathrm{Cq}$, also known as $\Delta \Delta \mathrm{Ct}$ ), where reads were normalized to both housekeeping genes (Hellemans et al., 2007). The equation to determine the relative quantity $(R Q)$ of each gene was the following $R Q=2^{(35-C t)}$. The $R Q$ values were divided by the geometric mean of the control genes relative quantity to obtain the normalized relative quantity (NRQ) then multiplied by 100 . After the relative expression was determined, the data was log-transformed before statistical analyses.

Ovarian Histology. Ovaries were removed after euthanasia, and the left ovary was frozen in liquid nitrogen for the RNA isolation while the right ovary was placed into $40 \%$ formalin for assessment of ovarian histology. Formalin- preserved ovaries were 
processed and stained with hematoxylin and eosin (H\&E) at the WVU histology core. Namely, the ovaries were embedded in paraffin, sectioned to $5 \mu \mathrm{m}$ sections until the entire ovary was used up, keeping the ribbon of the slices intact until mounting. Three serial sections were mounted on each slide, and the first and sixth of the consecutive slides from each mouse were stained for a total of six ovarian H\&E sections per mouse. Photographs of the entire ovarian area of six sections were taken using a Primo Star Microscope with AxioCam ERc5s camera (Zeiss, Thornwood, NY). The size of the ovarian area was estimated using Image J software (NIH, Bethesda, MD) on all H\&E sections of each ovary and average size estimated from six sections for the entire ovary. Similarly, numbers of primary, secondary, and antral follicles were determined at each of the six stained sections and averaged per ovary.

Analysis. All continuous variables were confirmed for normality of distribution by the Shapiro-Wilk W test. Most continuous variables in Trials 1 and 2 (weights, total splenocytes counts, hormonal concentrations, and gene expressions) were analyzed using $2 \times 2$ factorial ANOVA testing main effect of treatment (HKSP, HKSP + propanil), time (24 hours, 72 hours) and their interactions. A significant F-test was followed by multiple comparison tests- Tukey's honestly significant difference (HSD). All flow cytometry data (\% and counts), were analyzed by two-sided t-tests comparing HKSP and HKSP + propanil at 24 hours. Due to a large number (37) of similar analyses, Benjamini-Hochberg adjustment to multiple analyses was completed using a false discovery rate of 0.1 (Benjamini and Hochberg, 1995). The continuous variables from Trial 2 (weights and gene expressions) were analyzed by a two-sided t-test comparing 
HKSP and HKSP + propanil at 24 hours, followed by Benjamini-Hochberg adjustment to multiple analyses using a false discovery rate of 0.1 .

All continuous variables from Trial 3 (weights, splenocytes counts, flow cytometry percent and counts, hormonal concentrations, counts of ovarian follicles, ovarian area, and gene expressions) were analyzed using $2 \times 2$ factorial ANOVA testing main effect of propanil (peanut oil, propanil), antide (propyl. glycol, antide) and their interactions within the saline-treated and separately within HKSP-treated mice. In case a significant F-test was found, Tukey's Honestly Significant Differences (HSD) was determined. The salinetreated mice (without HKSP) served as an overall reference, as it was expected the HKSP, as an immune challenge, affects responses in a significant way, and statistical comparison of HKSP vs. saline (its control) was not the intention of this research.

All statistical analyses were conducted in $\mathrm{JMP}\left(\mathrm{JMP}^{\circledR}\right.$ version Pro 14.0, SAS Institute, Cary NC), and the significance criterion alpha for all tests was 0.05 . 


\section{Chapter 4: Results}

The first aim of these studies was to determine the acute effect of propanil with HKSP at 24 and 72 hours after exposure on splenic cell populations, reproductive hormones, ovarian, and oviductal gene expression. Experiments (trials 1 and 2) were designed to test the hypotheses that propanil not only affects the above tissues but also that this effect may be relatively short-lasting, thus different at hour 24 vs. 72 postexposure. Therefore, the interaction of treatment (propanil vs. control) and time $(24,72$ hours) in HKSP injected mice were tested. The second aim was to estimate if the acute effect of propanil at hour 24 is mediated by Gonadotropin-releasing hormone ( $\mathrm{GnRH}$ ) by utilizing $\mathrm{GnRH}$ antagonist, antide, and measuring the same dependent variables as in hypotheses of aim one. The main effect of antide and interaction of propanil and antide on immune and reproductive tissues from C57BI/6 female mice challenged with or without HKSP, in a similar model as above, where the purpose of trial 3. Table 2 lists significant findings and least square (LS) means standard error of the means (SEM) from trials 1 and 2 . Statistical analyses (factorial ANOVA) were done, and results ( $p$ values, LS means and SEM) from trial 3 are reported separately for groups without HKSP, listed in Table 3, and groups with HKSP, detailed in Table 4. Figures from all trials are interwoven together.

Propanil was related to a many-fold increase in spleen size on day 7 (Barnett et al., 1992b; Salazar et al., 2005, 2006). We observed about 20\% reduction in spleen weight at 24 hours but not at 72 hours (Figure 4 A, B), supported by more than $50 \%$ reduction of the total number of splenocytes (Figure 5 A, B). The antide effect was 
evaluated to test if the GnRH antagonist could modify these results. In mice without HKSP, the reduction of spleen size due to propanil was not significant and not affected by antide. In mice immunized with HKSP regardless (with or without) of antide propanil caused near $20 \%$ decrease in spleen weight (Figure 4 C). Antide, however, increased spleen weight in mice treated with HKSP and corn oil (without propanil).

Parallel to decrease in spleen weight, propanil exposure decreased the total number of spleen cells, but only in HKSP (Figure 5 A and B) at 24 hours. Overall control, reference treatment mice (without HKSP, antide, or propanil) had about $33 \pm 8$ x106 splenocytes. In HKSP-challenged, without propanil or antide, the counts were similar, although more variable, $37 \pm 15$ Million splenocytes. However, mice treated with HKSP and antide with or without propanil had double the number of splenocytes (about 65 Million) compared to the two groups treated without antide (about 30 Million) (Figure $5 \mathrm{~B}, \mathrm{HKSP}$ side), which would suggest $\mathrm{GnRH}$ involvement in the number of splenocytes. Multiple comparisons detected a significantly highest increase of splenocyte number ( $89 \pm 15$ Million splenocytes) in a group with HKSP, with antide and without propanil, over a group with HKSP, without antide, and with propanil.

Adaptive immune response, marked by a detected increase in antigen-specific antibodies takes typically 5-7 days (Owen et al., 2013) In the spleen of propanil/HKSPtreated mice, PC-specific IgG and IgM ASC peaked on day 7 (Wu et al., 1999; Salazar et al., 2005). We hypothesized that propanil might modify the elemental composition of the spleen as early as the second day after HKSP/propanil challenge. Flow cytometry results and LS means (cell percent and counts) and SEM of t-test comparing treatments at 24 hours are listed in Table 2. The specific cell populations affected by propanil 
include B cells (Figure 6), CD4 ${ }^{+} \mathrm{T}$ cells (Figure 7), $\mathrm{CD} 8^{+} \mathrm{T}$ cells (Figure 8), and CD11 $\mathrm{b}^{+}$cells (Figure 9). The percentage composition of the spleen was modified, such as percent of $\mathrm{B}$-cells decreased (Figure $6 \mathrm{~A}$ ), while the percent of $\mathrm{CD} 4^{+} \mathrm{T}$-cells did not change, (Figure 7A), percent of $C D 8^{+} \mathrm{T}$-cells increased (Figure 8A) and percent of granulocyte/monocytes (Figure 9A) increased due to propanil in trial 1. Decreased numbers in all four main cell types (Figures 6-9 B), such B-cells, CD4 ${ }^{+}$and $\mathrm{CD} 8^{+} \mathrm{T}-$ cells, and granulocyte/monocytes cells, due to propanil, matched the decrease in total cell number. Within the mice vaccinated with HKSP and exposed to antide, there was an increase in the number of B cells, indicated by the significant main effect of antide. On average, antide-treated mice had almost the double number of B-cells than HKSP mice without antide (regardless of propanil). Specific multiple comparisons pinpointed the difference mostly due to the antide without propanil group registering the highest number of B-cells (about $63 \pm 12$ Million) compared to without antide, propanil-treated, HKSP-challenged mice (about 13 Million \pm 12 B-cells) (Table 4, Figure 6 D).

T-cell function in thymus on days 2-4 (Cuff et al., 1996; Rosa et al., 2005), in the spleen on day 7 (Barnett and Gandy, 1989; Zhao et al., 1998) and in vitro functional assays with IL-2 and its intracellular transcription factors (24-48 hours) (Brundage et al., 2004; Lewis et al., 2008, 2013) were examined in propanil-treated mice and overall, general, decreased numbers and suppressed T-cell function/activation were observed. In this experiment, mice vaccinated with HKSP had a decrease in the splenic number of $\mathrm{CD}^{+} \mathrm{T}$ cells (Figure 7 B) 24 hours after exposure to propanil. The possible relationship of $\mathrm{GnRH}$ and T-cells stems from the evidence that $\mathrm{GnRH}$ receptor and its mRNA in spleen (and in thymus) was observed to fluctuate in a pattern identical to pituitary 
changes of $\mathrm{GnRH}$ receptor due to the cyclical hormonal changes (Jacobson et al., 1998) and $\mathrm{GnRH}$ is involved in T-cell development in thymus (Melnikova et al., 2019). Mice exposed to saline and antide had a decrease in percent CD4 ${ }^{+}$cells (Figure $7 \mathrm{C}$ ), suggesting that even without immune challenge, $\mathrm{GnRH}$ can affect the T-cells. Mice vaccinated with HKSP and exposed to propanil had almost a 50\% decrease in the number of $\mathrm{CD} 4^{+}$cells (Figure $7 \mathrm{D}$ ).

The percentages of $\mathrm{CD} 8^{+} \mathrm{T}$ cells (Figure $8 \mathrm{~A}$ ) populations were enhanced by propanil while the number of $\mathrm{CD} 8^{+} \mathrm{T}$ cells (Figure $8 \mathrm{~B}$ ) was decreased at 24 hours. Antide in the main effect decreased the percent of $\mathrm{CD} 8^{+}$cells in mice treated with saline (without HKSP) (Figure $8 \mathrm{C}$ ). However, the statistical significance versus the biological significance of the decrease in the percent of $\mathrm{CD}^{+} \mathrm{T}$ cells from about $3.5 \%$ to $2.5 \%$ needs to be addressed. The number of $\mathrm{CD} 8^{+}$cells increased in mice treated with HKSP and antide with or without propanil (Figure 8 D). Multiple comparisons within the HKSPchallenged group detected a higher number of $\mathrm{CD} 8^{+} \mathrm{T}$ cells in antide group without propanil than without antide with propanil.

CD11b is a marker expressed on the surface of many leukocytes, including monocytes, neutrophils, natural killer cells, granulocytes, and macrophages, and about $8 \%$ of spleen cells. Lytic activity of NK cells from spleen was decreased with $50 \mathrm{mg} / \mathrm{kg}$ dose of propanil on day 7 (Barnett et al., 1992), but numbers or percent different font of CD11 $\mathrm{b}^{+}$cells were not enumerated on in 24 hours after propanil. Results indicated the mice treated with propanil showed an increase in the percent of CD11 $\mathrm{b}^{+}$cells (Figure 9 A) but a decrease in the number of $\mathrm{CD} 11 \mathrm{~b}^{+}$cells (Figure 9 B). In a macaque corpus luteum, antide treatment increased the number of CD11 b ${ }^{+}$cells (Bishop et al., 2015). 
Within mice vaccinated with HKSP and exposed to antide, there was a main effect of antide demonstrated by a decrease in percent $C D 11 b^{+}$cells, more so in the group without propanil (Figure $9 \mathrm{C}$ ).

We hypothesized that propanil would modify hormones involved in ovarian function, and antide interfere with this effect. Concentrations of prolactin were higher in propanil treated than control in HKSP vaccinated mice at 24 hours (Figure 10 A, B); however, antide did not modify the propanil's effect on prolactin. The concentrations of progesterone were statistically enhanced only at 24 hours in propanil treated mice (Figure $10 \mathrm{C}$ ), demonstrated by a significant interaction of treatment and time. There was no significant difference in progesterone concentrations (Figure $10 \mathrm{D}$ ) after mice were treated with propanil and antide. There was not a significant difference in estradiol concentrations (Figure $10 \mathrm{E}$ ) in the propanil treated mice at either time point, while mice exposed to propanil without HKSP demonstrated a decrease in estradiol concentration (Figure $10 \mathrm{~F}$ ) within the serum.

Efficacy of antide was verified by decreased ovarian weight and area and uterine weight shown both with or without HKSP (Figure 11 A, B, and Figure 12, Figure 13). This decrease likely happens indirectly via the HPG axis through the decreased output of luteinizing ( $\mathrm{LH}$ ) and follicle-stimulating hormone (FSH) from pituitary after lack of $\mathrm{GnRH}$-stimulation with antide. However, $\mathrm{GnRH}$ receptors are also present in ovaries.

The propanil effect on ovaries at 24 hours was tested as a first step in answering why are ovaries required to induce PC-specific ASC number in the spleen observed in earlier studies (Salazar et al., 2006). Propanil caused a decrease in ovarian weight in 
mice treated with saline (Figure 11 A). Hypotheses were tested about propanil affecting specifically chosen gene expression. Genes in the ovaries involved in steroid synthesis, ovulation, extracellular and remodeling molecules, as well as inflammatory markers, were studied, and the interaction of antide with propanil on the gene expressions was also examined.

Propanil caused a significant increase in Dhcr7 (7-dehydrocholesterol reductase) mRNA abundance at 24 hours but not at 72 hours (Figure 14 A), established by a significant interaction of treatment and time. Antide decreased the mRNA expression of Dhcr7 in mice treated in saline and HKSP (Figure 14 B). Cyp17a1 (17a-hydroxylase) mRNA expression decreased in the propanil treated mice at 24 hours (Figure $14 \mathrm{C}$ ), demonstrated by a significant interaction of treatment and time. A significant interaction of propanil and antide was observed in mice vaccinated with HKSP; a decrease in Cyp17a1 mRNA that was observed in propanil treated mice was eliminated by antide injection (Figure $14 \mathrm{D}$ ). Mice treated with propanil demonstrated a decrease in gene expression of Cyp19a1 (aromatase) mRNA expression at 24 hours (Figure $14 \mathrm{E}$ ). Mice vaccinated with HKSP and exposed to propanil decreased Cyp19a1 (Figure 14 F) mRNA expression. Antide decreased the expression of Cyp19a1 in mice vaccinated with HKSP. Hsd17b2 mRNA abundance showed a significant effect of time between 24 and 72 hours (Figure $14 \mathbf{G}$ ). HKSP vaccinated mice had a decreased in Hsd17b2 expression after being treated with antide (Figure $14 \mathrm{H}$ ).

Antide decreased the mRNA expression of Cyp11b1 in mice vaccinated with HKSP, and the saline-treated mice (Figure $14 \mathrm{I}$ ). Mice treated with saline and antide or vaccinated with HKSP and antide showed a decrease in mRNA expression of $H s d 17 b 7$ 
when compared to mice treated without antide (Figure $14 \mathrm{~J}$ ). Increase in expression of Gnrhr mRNA in mice treated with antide with or without HKSP (Figure 1J K).

The expression of Irf1 increased in both saline-treated and HKSP-vaccinated mice treated with antide (Figure 15 A). Propanil increased expression of Iff1 in mice treated with saline (Figure 15 A). Propanil increased expression of Socs3 in mice vaccinated with HKSP while antide also increased expression in mice treated with saline (Figure 15 B).

Propanil increased the expression of $L c n 2$ (Figure 16) at 24 hours but not at 72 hours after exposure. Antide increased expression of Adamts1 (Figure 17 A), Csf1 (Figure $17 \mathrm{~B}$ ), and $\mathrm{Cxc} / 10$ (Figure $17 \mathrm{D}$ ) in mice treated with saline or vaccinated with HKSP. In saline-treated mice, there was an increase in Cxcl1 expression (Figure $17 \mathrm{C}$ ). In mice vaccinated with HSKP or treated with saline, antide increased the expression in mRNA of $/ / 10$ (Figure $17 \mathrm{E}$ ), and TIr2 (Figure 17 F). A significant interaction of propanil and antide on Saa3 mRNA expression was observed in mice vaccinated with HKSP; without antide no changes were observed due to propanil, but with the addition of antide, in peanut oil group had an increase in Saa3 mRNA expression in ovaries, giving an impression the propanil decrease the Saa3 in antide-treated mice (Figure $17 \mathbf{~ G}$ ).

Propanil had no effect on gene expression on any of the 22 genes analyzed (Table 1) from the oviductal tissue of female mice exposed to propanil and HKSP. 


\begin{tabular}{|c|c|c|c|c|c|}
\hline Gene Name & $\begin{array}{c}\text { Gene } \\
\text { Symbol }\end{array}$ & Forward Primer $\left(5^{\prime} \rightarrow 3^{\prime}\right)$ & Reverse Primer $\left(5^{\prime} \rightarrow 3^{\prime}\right)$ & Length & $\begin{array}{c}\text { Efficiency } \\
(\%)\end{array}$ \\
\hline Interferon regulatory factor 1 & Irf1 & ATGCCAATCACTCGAATGCG & CCTGCTTTGTATCGGCCTGT & 203 & 94 \\
\hline Suppressor of cytokine signaling 3 & Socs3 & ATGGTCACCCACAGCAAGTTT & TCCAGTAGAATCCGCTCTCCT & 145 & 101 \\
\hline Cytochrome P450 17A1 & Cyp17a1 & GCCCAAGTCAAAGACACCTAAT & GTACCCAGGCGAAGAGAATAGA & 159 & 96 \\
\hline Cytochrome P450 11B1 & Cyp11b1 & CAGATTGTGTTTGTGACGTTGC & CGGTTGAAGTACCATTCTGGC & 164 & 108 \\
\hline Cytochrome P450 19A1 & Cyp19a1 & ATGTTCTTGGAAATGCTGAACCC & AGGACCTGGTATTGAAGACGAG & 150 & 99 \\
\hline Hydroxysteroid 17-Beta Dehydrogenase 2 & Hsd17b2 & ATGAGCCCGTTTGCCTCTG & CCACAGGTAACAAGTCTTGGTC & 244 & 93 \\
\hline Hydroxysteroid 17-Beta Dehydrogenase 7 & Hsd17b7 & CCACCTGTGTTTGGCGTGTA & GAGGTTGAATTGTGGATTAGGCA & 217 & 93 \\
\hline 7-Dehydrocholesterol reductase & Dhcr7 & AGGCTGGATCTCAAGGACAAT & GCCAGACTAGCATGGCCTG & 184 & 94 \\
\hline S100 calcium-binding protein A1 & S100a8 & AAATCACCATGCCCTCTACAAG & CCCACTTTTATCACCATCGCAA & 165 & 93 \\
\hline C-X-C Motif Chemokine Ligand 1 & $\mathrm{Cxcl} 1$ & CTGGGATTCACCTCAAGAACATC & CAGGGTCAAGGCAAGCCTC & 117 & 98 \\
\hline C-X-C Motif Chemokine Ligand 10 & Cxcl10 & CCAAGTGCTGCCGTCATTTTC & GGCTCGCAGGGATGATTTCAA & 157 & 94 \\
\hline C-C Motif Chemokine Ligand 2 & $\mathrm{Ccl} 2$ & TTAAAAACCTGGATCGGAACCAA & GCATTAGCTTCAGATTTACGGGT & 121 & 90 \\
\hline Colony Stimulating Factor 1 & Csf1 & GTGTCAGAACACTGTAGCCAC & TCAAAGGCAATCTGGCATGAAG & 101 & 96 \\
\hline Lipocalin 2 & Lcn2 & TGGCCCTGAGTGTCATGTG & CTCTTGTAGCTCATAGATGGTGC & 239 & 94 \\
\hline Serum Amyloid A 3 & Saa3 & TGCCATCATTCTTTGCATCTTGA & CCGTGAACTTCTGAACAGCCT & 248 & 90 \\
\hline Toll-like receptor 2 & TIr2 & GCAAACGCTGTTCTGCTCAG & AGGCGTCTCCCTCTATTGTATT & 231 & 100 \\
\hline $\begin{array}{l}\text { A Disintegrin And Metalloproteinase with } \\
\text { Thrombospondin Motifs } 1\end{array}$ & Adamts1 & TACTGACTTCCTGGATAGTGGG & TGGCTCAAACTGTAGCTTGTG & 105 & 98 \\
\hline Carbonic Anhydrase 3 & Car3 & TGACAGGTCTATGCTGAGGGG & CAGCGTATTTTACTCCGTCCAC & 125 & 93 \\
\hline Gonadotropin Releasing Hormone Receptor & Gnrhr & TGCTCGGCCATCAACAACA & GGCAGTAGAGAGTAGGAAAAGGA & 114 & 110 \\
\hline Tumor Necrosis Factor, Alpha-induced Protein 3 & Tnfaip3 & CTGGATGTCAATCAACAATGGGA & ACTAGGGTGTGAGTGTTTTCTGT & 116 & 102 \\
\hline Interleukin 6 & $1 / 6$ & AGCCAGAGTCCTTCAGAGAGA & TGGTCTTGGTCCTTAGCCAC & 155 & 93 \\
\hline Interleukin 10 & $/ / 10$ & GCTCTTACTGACTGGCATGAG & CGCAGCTCTAGGAGCATGTG & 105 & 106 \\
\hline B-Actin & Actb & GGCTGTATTCCCCTCCATCG & CCAGTTGGTAACAATGCCATGT & 154 & 94 \\
\hline Hypoxanthine-guanine phosphoribosyltransferase & Hprt1 & CAGTCCCAGCGTCGTGATTA & GGCCTCCCATCTCCTTCATG & 167 & 93 \\
\hline
\end{tabular}

Table 1. Primer sequences for genes analyzed by qRT-PCR. The names of genes analyzed, the sequences for the

primers, length, and efficiency for all genes in all trials are listed in their respective columns. 


\begin{tabular}{|c|c|c|c|c|c|}
\hline \multirow[b]{2}{*}{ Organ } & \multirow[b]{2}{*}{ Variable } & \multicolumn{2}{|c|}{24 Hours } & \multicolumn{2}{|c|}{72 Hours } \\
\hline & & HKSP & HKSP + Propanil & HKSP & HKSP + Propanil \\
\hline \multirow[t]{10}{*}{ Spleen } & Spleen Weight (mg) & $71.67 \pm 2.288^{a}$ & $55.00 \pm 2.288^{b}$ & $78.33 \pm 2.288^{a}$ & $72.00 \pm 2.506^{a}$ \\
\hline & Splenocyte Count & $81 \times 10^{6} \pm 10 \times 10^{6}$ a & $29 \times 10^{6} \pm 10 \times 10^{6} b$ & $105 \times 10^{6} \pm 10 \times 10^{6} \mathrm{a}$ & $98 \times 10^{6} \pm 12 \times 10^{6} \mathrm{a}$ \\
\hline & Percent B220 ${ }^{+}$Cells & $60.64 \pm 1.57^{a}$ & $48.74 \pm 1.57^{b}$ & $\mathrm{~N} / \mathrm{A}$ & $\mathrm{N} / \mathrm{A}$ \\
\hline & Number B220 ${ }^{+}$Cells & $49 \times 10^{6} \pm 5 \times 10^{6} \mathrm{a}$ & $14 \times 10^{6} \pm 5 \times 10^{6} b$ & $\mathrm{~N} / \mathrm{A}$ & $\mathrm{N} / \mathrm{A}$ \\
\hline & Percent CD4 ${ }^{+}$Cells & $13.20 \pm 0.79 a$ & $14.13 \pm 0.79$ a & $\mathrm{N} / \mathrm{A}$ & $\mathrm{N} / \mathrm{A}$ \\
\hline & Number CD4 ${ }^{+}$Cells & $10 \times 10^{6} \pm 8 \times 10^{5} \mathrm{a}$ & $4 \times 10^{6} \pm 8 \times 10^{5} b$ & $\mathrm{~N} / \mathrm{A}$ & $\mathrm{N} / \mathrm{A}$ \\
\hline & Percent CD8 ${ }^{+}$Cells & $3.95 \pm 0.22 \mathrm{a}$ & $5.79 \pm 0.22^{b}$ & N/A & $\mathrm{N} / \mathrm{A}$ \\
\hline & Number CD8 ${ }^{+}$Cells & $3 \times 10^{6} \pm 3 \times 10^{5} \mathrm{a}$ & $2 \times 10^{6} \pm 3 \times 10^{5 b}$ & $\mathrm{~N} / \mathrm{A}$ & $\mathrm{N} / \mathrm{A}$ \\
\hline & Percent CD11b+ Cells & $5.57 \pm 0.68$ & $9.43 \pm 0.67 b$ & $\mathrm{~N} / \mathrm{A}$ & $\mathrm{N} / \mathrm{A}$ \\
\hline & Number CD11b+ Cells & $5 \times 10^{6} \pm 5 \times 10^{5}$ & $3 \times 10^{6} \pm 5 \times 10^{5} b$ & $\mathrm{~N} / \mathrm{A}$ & $\mathrm{N} / \mathrm{A}$ \\
\hline \multirow[t]{3}{*}{ Blood } & Prolactin (ng/ml) & $99.06 \pm 17.19$ a & $172.36 \pm 17.19^{b}$ & $94.58 \pm 17.19$ a & $102.78 \pm 18.84^{a b}$ \\
\hline & Progesterone (ng/ml) & $4.10 \pm 0.59$ & $7.40 \pm 0.59 \mathrm{~b}$ & $3.91 \pm 0.59 a$ & $3.30 \pm 0.65^{a}$ \\
\hline & Estradiol (pg/ml) & $3.198 \pm 0.349^{a}$ & $3.718 \pm 0.349 a$ & $3.378 \pm 0.349$ a & $4.423 \pm 0.383^{a}$ \\
\hline \multirow[t]{4}{*}{ Ovaries } & Dhcr7 Expression & $0.003 \pm 0.05^{a}$ & $0.35 \pm 0.05^{b}$ & $-0.17 \pm 0.05 \mathrm{ac}$ & $-0.20 \pm 0.05^{c}$ \\
\hline & Cyp17a1 Expression & $-0.30 \pm 0.17^{a}$ & $-1.08 \pm 0.17^{b}$ & $0.63 \pm 0.17^{c}$ & $0.75 \pm 0.19^{c}$ \\
\hline & Cyp19a1 Expression & $-0.07 \pm 0.08$ & $-0.50 \pm 0.08 b$ & $0.37 \pm 0.08^{c}$ & $0.10 \pm 0.09$ ac \\
\hline & Hsd17b2 Expression & $-0.04 \pm 0.06^{a b}$ & $-0.21 \pm 0.06^{b}$ & $0.11 \pm 0.06^{a}$ & $0.17 \pm 0.07^{a}$ \\
\hline
\end{tabular}

Table 2. Effect of propanil and time after HKSP/propanil on spleen weight, spleen cell populations, systemic

hormones, and ovarian gene expression for trial 1. Female C57BI/6 mice were immunized with $\mathrm{HKSP}\left(2 \times 10^{8} \mathrm{CFU} / \mathrm{ml}\right)$

and injected (i.p., $200 \mathrm{mg} / \mathrm{kg}$ ) with propanil 24 or 72 hours before euthanasia. Heart-puncture-blood, spleen, ovaries, and oviducts were immediately collected (trials 1 and 2). Total spleen cell count was determined by hemocytometer and trypan blue exclusion. Hormones were measured in serum utilizing specific ELISAs. Total RNA from both ovaries was extracted, reversely transcribed to cDNA before the mRNA expression was measured by qRT-PCR for genes involved in 
steroid synthesis, inflammation, or ovarian remodeling (listed in Table 1). A significant F-test in a two-way ANOVA was followed by a multiple comparison test -Tukey's honestly significant difference (HSD). Least Square means \pm SEM for each treatment group are listed for only variables that were significantly affected by treatment or by the interaction of treatment and time. Superscripts correspond to HSD within each row, such that any pair with differing superscript letters are different from each other. For example, in prolactin measured in blood, group with superscript a (HKSP in 24 hours, $99.06 \mathrm{ng} / \mathrm{ml}$ ) differs statistically from group with superscript b (HKSP+Propanil in 24 hours, 172.36), but the first group (HKSP in 24 hours, 99.06) $)^{a}$ is not different from the third group (HKSP in 72 hours, $\left.94.58 \mathrm{ng} / \mathrm{ml}\right)^{\mathrm{a}}$ that is why the third group has the same superscript, a. The fourth group (HKSP+Propanil in 72 hours, $102.78 \mathrm{ng} / \mathrm{ml}$ ) has superscript ab, and since $\mathbf{a}$ in $\mathbf{a b}$ is the shared letter with group one $(99.06)^{\mathbf{a}}$ and three $(94.58 \mathrm{ng} / \mathrm{ml})^{\mathbf{a}}$, it indicates it is not different from either of those, and it is also not different from the second group, as they share the superscript $\mathbf{b}$. 
Treatment

Saline (without HKSP)

Propyl. Glycol Antide

\begin{tabular}{|c|c|c|c|c|c|c|}
\hline Organ & Variable & Significant Effect & Peanut Oil & Propanil & Peanut Oil & Propanil \\
\hline \multirow[t]{10}{*}{ Spleen } & Spleen Weight (mg) & Propanil (0.0143) & $71.233 \pm 4.883$ & $58.533 \pm 4.883$ & $79.5 \pm 4.883$ & $66 \pm 4.883$ \\
\hline & Splenocyte Count $\left(1 \times 10^{6}\right)$ & NS & $33.434 \pm 8.419$ & $22.304 \pm 8.419$ & $33.7 \pm 8.419$ & $28.552 \pm 8.419$ \\
\hline & Percent B220 ${ }^{+}$Cells & NS & $54.308 \pm 3.353$ & $53.158 \pm 3.353$ & $62.192 \pm 3.353$ & $56.96 \pm 3.353$ \\
\hline & Number B220 $0^{+}$Cells $\left(1 \times 10^{6}\right)$ & NS & $18.975 \pm 5.263$ & $12.915 \pm 5.263$ & $20.816 \pm 5.263$ & $15.515 \pm 5.263$ \\
\hline & Percent CD $4^{+}$Cells & Antide $(0.0087)$ & $21.48 \pm 1.337$ & $23.72 \pm 1.337$ & $17.87 \pm 1.337$ & $19.555 \pm 1.337$ \\
\hline & Number CD $4^{+}$Cells $\left(1 \times 10^{6}\right)$ & NS & $6.449 \pm 1.381$ & $4.97 \pm 1.381$ & $5.95 \pm 1.381$ & $5.309 \pm 1.381$ \\
\hline & Percent CD8 ${ }^{+}$Cells & Antide $(0.0286)$ & $2.05 \pm 0.272$ & $2.8 \pm 0.272$ & $1.607 \pm 0.272$ & $1.793 \pm 0.272$ \\
\hline & Number CD $8^{+}$Cells $\left(1 \times 10^{6}\right)$ & NS & $0.988 \pm 0.184$ & $0.491 \pm 0.184$ & $0.665 \pm 0.184$ & $0.626 \pm 0.184$ \\
\hline & Percent CD11b ${ }^{+}$Cells & NS & $11.61 \pm 1.734$ & $11.452 \pm 1.734$ & $8.257 \pm 1.734$ & $8.473 \pm 1.734$ \\
\hline & Number CD $11 \mathrm{~b}^{+}$Cells $\left(1 \times 10^{6}\right)$ & NS & $2.794 \pm 0.464$ & $2.22 \pm 0.464$ & $2.623 \pm 0.464$ & $2.123 \pm 0.464$ \\
\hline \multirow[t]{3}{*}{ Blood } & Prolactin (ng/ml) & NS & $22.598 \pm 5.25$ & $35.571 \pm 5.25$ & $28.687 \pm 5.25$ & $31.325 \pm 5.25$ \\
\hline & Progesterone (pg/ml) & NS & $5.859 \pm 0.99$ & $6.066 \pm 0.99$ & $6.198 \pm 0.99$ & $6.42 \pm 0.99$ \\
\hline & Estradiol (pg/ml) & Propanil (0.0232) & $5.284 \pm 0.524$ & $4.031 \pm 0.524$ & $5.132 \pm 0.524$ & $3.809 \pm 0.524$ \\
\hline Uterus & Uterine Weight (mg) & Antide (0.0394) & $71.4 \pm 7.346$ & $61.167 \pm 6.706$ & $51.16 \pm 7.346$ & $50.167 \pm 6.706$ \\
\hline \multirow[t]{18}{*}{ Ovary } & Ovarian Weight (mg) & Propanil (0.017) Antide $(<0.0001)$ & $8.667 \pm 0.544$ & $6.433 \pm 0.544$ & $5 \pm 0.596$ & $4.317 \pm 0.544$ \\
\hline & Ovarian Area $\left(\mathrm{mm}^{2}\right)$ & Antide $(0.0243)$ & $192.782 \pm 30.895$ & $193.317 \pm 28.203$ & $133.522 \pm 28.203$ & $107.099 \pm 30.895$ \\
\hline & Adamts1 Expression & Antide $(0.0025)$ & $-0.16 \pm 0.053$ & $-0.061 \pm 0.053$ & $0.131 \pm 0.053$ & $0.105 \pm 0.053$ \\
\hline & Csf1 Expression & Antide $(0.0055)$ & $-0.126 \pm 0.039$ & $-0.05 \pm 0.039$ & $0.036 \pm 0.039$ & $0.079 \pm 0.039$ \\
\hline & Cxcl1 Expression & Antide $(0.0005)$ & $-0.228 \pm 0.051$ & $-0.125 \pm 0.051$ & $0.104 \pm 0.051$ & $0.111 \pm 0.051$ \\
\hline & Cxcl10 Expression & Antide $(0.0095)$ & $-0.161 \pm 0.068$ & $-0.078 \pm 0.068$ & $0.087 \pm 0.068$ & $0.136 \pm 0.068$ \\
\hline & Cyp11b1 Expression & Antide $(0.0371)$ & $1.669 \pm 0.536$ & $0.562 \pm 0.536$ & $-0.323 \pm 0.536$ & $-0.125 \pm 0.536$ \\
\hline & Cyp17a1 Expression & NS & $0.194 \pm 0.316$ & $-0.584 \pm 0.316$ & $0.39 \pm 0.316$ & $0.242 \pm 0.316$ \\
\hline & Cyp19a1 Expression & NS & $-0.088 \pm 0.119$ & $-0.125 \pm 0.119$ & $0.154 \pm 0.119$ & $0.022 \pm 0.119$ \\
\hline & Dhcr7 Expression & Antide $(0.0048)$ & $0.276 \pm 0.081$ & $0.137 \pm 0.081$ & $-0.21 \pm 0.081$ & $-0.003 \pm 0.081$ \\
\hline & Gnrhr Expression & Antide $(0.0003)$ & $-0.284 \pm 0.072$ & $-0.179 \pm 0.072$ & $0.193 \pm 0.072$ & $0.224 \pm 0.072$ \\
\hline & Hsd17b2 Expression & NS & $-0.022 \pm 0.059$ & $-0.07 \pm 0.059$ & $0.065 \pm 0.059$ & $0.065 \pm 0.059$ \\
\hline & Hsd17b7 Expression & Antide (0.0074) & $0.57 \pm 0.255$ & $0.537 \pm 0.255$ & $-0.404 \pm 0.255$ & $-0.305 \pm 0.255$ \\
\hline & /10 Expression & Antide $(0.0005)$ & $-0.275 \pm 0.072$ & $-0.148 \pm 0.072$ & $0.186 \pm 0.072$ & $0.193 \pm 0.072$ \\
\hline & Irf1 Expression & Propanil (0.0053) Antide $(<0.0001)$ & $-0.134 \pm 0.02$ & $-0.08 \pm 0.02$ & $0.012 \pm 0.02$ & $0.112 \pm 0.02$ \\
\hline & Saa3 Expression & NS & $0.368 \pm 0.344$ & $-0.501 \pm 0.344$ & $0.197 \pm 0.344$ & $-0.286 \pm 0.344$ \\
\hline & Socs3 Expression & Antide $(0.0037)$ & $-0.087 \pm 0.044$ & $-0.152 \pm 0.044$ & $0.03 \pm 0.044$ & $0.089 \pm 0.044$ \\
\hline & TIr2 Expression & Antide $(0.002)$ & $-0.152 \pm 0.041$ & $-0.047 \pm 0.041$ & $0.091 \pm 0.041$ & $0.079 \pm 0.041$ \\
\hline
\end{tabular}


Table 3. Effect of antide after saline/propanil on spleen weight, spleen cell populations, systemic hormones, and ovarian gene expression for mice without the immune challenge. Female C57BI/6 mice were repeatedly injected (s.q.) with antide (or propylene glycol as control), immunized with HKSP $\left(2 \times 10^{8} \mathrm{CFU} / \mathrm{ml}\right)$ or saline and injected (i.p., 200 $\mathrm{mg} / \mathrm{kg}$ ) with propanil or peanut oil 24 hours before euthanasia. Heart-puncture-blood, spleen, ovaries, and uterus were immediately collected (trial 3). Total spleen cell count was determined by hemocytometer and trypan blue exclusion. Hormones were measured in serum utilizing specific ELISAs as described in methods. Total RNA from both ovaries was extracted, reversely transcribed to cDNA before the mRNA expression was measured by qRT-PCR for genes involved in steroid synthesis, inflammation, or ovarian remodeling (listed in Table 1). A significant F-test in a two-way ANOVA was followed by multiple comparison tests -Tukey's honestly significant difference (HSD). Least Square means \pm SEM for each treatment group are listed for only variables that were significantly affected by treatment or by the interaction of treatment and time. 


\begin{tabular}{|c|c|c|c|c|c|c|}
\hline \multirow[b]{3}{*}{ Organ } & \multirow[b]{3}{*}{ Variable } & \multirow[b]{3}{*}{ Significant effect } & \multicolumn{4}{|c|}{$\begin{array}{c}\text { Treatment } \\
\text { HKSP }\end{array}$} \\
\hline & & & \multicolumn{2}{|c|}{ Propyl. Glycol } & \multicolumn{2}{|c|}{ Antide } \\
\hline & & & Peanut Oil & Propanil & Peanut Oil & Propanil \\
\hline \multirow[t]{10}{*}{ Spleen } & Spleen Weight (mg) & Propanil $(<0.0001)$ Antide $(0.0147)$ & $73.667 \pm 3.682$ & $50.333 \pm 3.682$ & $88.167 \pm 3.682$ & $55.5 \pm 3.682$ \\
\hline & Splenocyte Count $\left(1 \times 10^{6}\right)$ & Propanil (0.0437) Antide (0.0364) & $37.013 \pm 15.415$ & $22.165 \pm 15.415$ & $89.919 \pm 15.415$ & $38.39 \pm 15.415$ \\
\hline & Percent B220 ${ }^{+}$Cells & NS & $57.993 \pm 3.434$ & $55.953 \pm 3.434$ & $67.223 \pm 3.434$ & $60.343 \pm 3.434$ \\
\hline & Number B220 ${ }^{+}$Cells $\left(1 \times 10^{6}\right)$ & Antide (0.0424) & $22.701 \pm 11.9$ & $12.971 \pm 11.9$ & $63.03 \pm 11.9$ & $24.241 \pm 11.9$ \\
\hline & Percent CD4 ${ }^{+}$Cells & NS & $19.622 \pm 1.53$ & $19.912 \pm 1.53$ & $15.482 \pm 1.53$ & $20.037 \pm 1.53$ \\
\hline & Number CD4 ${ }^{+}$Cells $\left(1 \times 10^{6}\right)$ & Propanil (0.0473) & $7.109 \pm 2.295$ & $4.152 \pm 2.295$ & $13.333 \pm 2.295$ & $6.592 \pm 2.295$ \\
\hline & Percent CD ${ }^{+}$Cells & NS & $1.7 \pm 0.205$ & $1.753 \pm 0.205$ & $1.617 \pm 0.205$ & $1.907 \pm 0.205$ \\
\hline & Number CD $8^{+}$Cells $\left(1 \times 10^{6}\right)$ & Antide (0.0151) & $0.449 \pm 0.206$ & $0.296 \pm 0.206$ & $1.229 \pm 0.206$ & $0.785 \pm 0.206$ \\
\hline & Percent CD11 $\mathrm{b}^{+}$Cells & Antide (0.0216) & $9.58 \pm 0.967$ & $10.332 \pm 0.967$ & $6.428 \pm 0.967$ & $8.662 \pm 0.967$ \\
\hline & Number CD11 ${ }^{+}$Cells $\left(1 \times 10^{6}\right)$ & NS & $3.512 \pm 1.242$ & $2.431 \pm 1.242$ & $5.922 \pm 1.242$ & $2.901 \pm 1.242$ \\
\hline \multirow[t]{3}{*}{ Blood } & Prolactin $(\mathrm{ng} / \mathrm{ml})$ & Propanil (0.0173) & $31.986 \pm 8.519$ & $56.48 \pm 8.519$ & $32.604 \pm 8.519$ & $52.311 \pm 8.519$ \\
\hline & Progesterone (pg/ml) & NS & $6.386 \pm 1.335$ & $8.789 \pm 1.335$ & $6.23 \pm 1.335$ & $6.78 \pm 1.335$ \\
\hline & Estradiol (pg/ml) & Propanil $(<0.0001)$ & $6.225 \pm 0.418$ & $4.522 \pm 0.418$ & $5.931 \pm 0.418$ & $3.582 \pm 0.418$ \\
\hline Uterus & Uterine Weight (mg) & NS & $81 \pm 12.823$ & $68.5 \pm 12.823$ & $46.017 \pm 12.823$ & $68.95 \pm 12.823$ \\
\hline \multirow[t]{18}{*}{ Ovary } & Ovarian Weight (mg) & Antide $(<0.0001)$ & $6.75 \pm 0.476$ & $6.233 \pm 0.476$ & $4.067 \pm 0.476$ & $4 \pm 0.476$ \\
\hline & Ovarian Area $\left(\mathrm{mm}^{2}\right)$ & Antide (0.008) & $181.537 \pm 21.175$ & $202.436 \pm 21.175$ & $99.35 \pm 21.175$ & $159.816 \pm 21.175$ \\
\hline & Adamts1 Expression & Antide (0.0361) & $-0.128 \pm 0.049$ & $-0.003 \pm 0.049$ & $0.068 \pm 0.049$ & $0.048 \pm 0.049$ \\
\hline & Csf1 Expression & Antide (0.0319) & $-0.059 \pm 0.032$ & $0.008 \pm 0.032$ & $0.04 \pm 0.032$ & $0.073 \pm 0.032$ \\
\hline & Cxcl1 Expression & NS & $-0.036 \pm 0.069$ & $-0.007 \pm 0.069$ & $0.021 \pm 0.069$ & $0.159 \pm 0.069$ \\
\hline & Cxcl10 Expression & Antide (0.0183) & $-0.02 \pm 0.061$ & $-0.153 \pm 0.061$ & $0.084 \pm 0.061$ & $0.105 \pm 0.061$ \\
\hline & Cyp11b1 Expression & Antide (0.0123) & $0.217 \pm 0.276$ & $-0.221 \pm 0.276$ & $-1.082 \pm 0.276$ & $-0.697 \pm 0.276$ \\
\hline & Cyp17a1 Expression & Propanil (0.0002) Antide*Propanil (0.0088) & $0.659 \pm 0.149$ & $-0.815 \pm 0.149$ & $0.179 \pm 0.149$ & $-0.266 \pm 0.149$ \\
\hline & Cyp19a1 Expression & Propanil (0.013) Antide (0.0353) & $0.444 \pm 0.126$ & $-0.105 \pm 0.126$ & $-0.023 \pm 0.126$ & $-0.277 \pm 0.126$ \\
\hline & Dhcr7 Expression & Antide (0.0291) & $-0.002 \pm 0.12$ & $0.221 \pm 0.12$ & $-0.131 \pm 0.12$ & $-0.288 \pm 0.12$ \\
\hline & Gnrhr Expression & Antide $(0.0052)$ & $-0.17 \pm 0.077$ & $-0.1 \pm 0.077$ & $0.199 \pm 0.077$ & $0.117 \pm 0.077$ \\
\hline & Hsd17b2 Expression & Antide (0.049) & $0.01 \pm 0.078$ & $-0.21 \pm 0.078$ & $0.108 \pm 0.078$ & $0.053 \pm 0.078$ \\
\hline & Hsd17b7 Expression & Antide (0.0262) & $0.022 \pm 0.176$ & $0.258 \pm 0.176$ & $-0.349 \pm 0.176$ & $-0.329 \pm 0.176$ \\
\hline & I/10 Expression & Antide (0.0103) & $-0.184 \pm 0.067$ & $-0.018 \pm 0.067$ & $0.147 \pm 0.067$ & $0.099 \pm 0.067$ \\
\hline & Irf1 Expression & Antide (0.0002) & $-0.054 \pm 0.018$ & $-0.017 \pm 0.018$ & $0.066 \pm 0.018$ & $0.096 \pm 0.018$ \\
\hline & Saa3 Expression & Antide*Propanil $(0.0215)$ & $-0.213 \pm 0.174$ & $-0.031 \pm 0.174$ & $0.637 \pm 0.174$ & $-0.171 \pm 0.174$ \\
\hline & Socs3 Expression & Propanil (0.0261) & $-0.134 \pm 0.054$ & $0.098 \pm 0.054$ & $0.048 \pm 0.054$ & $0.108 \pm 0.054$ \\
\hline & TIr2 Expression & Antide $(0.006)$ & $-0.017 \pm 0.031$ & $-0.083 \pm 0.031$ & $0.079 \pm 0.031$ & $0.051 \pm 0.031$ \\
\hline
\end{tabular}


Table 4. Effect of antide after HKSP/propanil on spleen weight, spleen cell populations, systemic hormones, and ovarian gene expression for mice treated with HKSP. Female C57BI/6 mice were repeatedly injected (s.q.) with antide (or propylene glycol as control), immunized with HKSP $\left(2 \times 10^{8} \mathrm{CFU} / \mathrm{ml}\right)$ or saline and injected (i.p., $\left.200 \mathrm{mg} / \mathrm{kg}\right)$ with propanil or peanut oil 24 hours before euthanasia. Heart-puncture-blood, spleen, ovaries, and uterus were immediately collected (trial 3). Total spleen cell count was determined by hemocytometer and trypan blue exclusion. Hormones were measured in serum utilizing specific ELISAs. Total RNA from both ovaries was extracted, reversely transcribed to cDNA before the mRNA expression was measured by qRT-PCR for genes involved in steroid synthesis, inflammation, or ovarian remodeling (listed in Table 1). A significant F-test in a two-way ANOVA was followed by multiple comparison test -Tukey's honestly significant difference (HSD). Least Square means \pm SEM for each treatment group are listed for only variables that were significantly affected by treatment or by the interaction of treatment and time. 

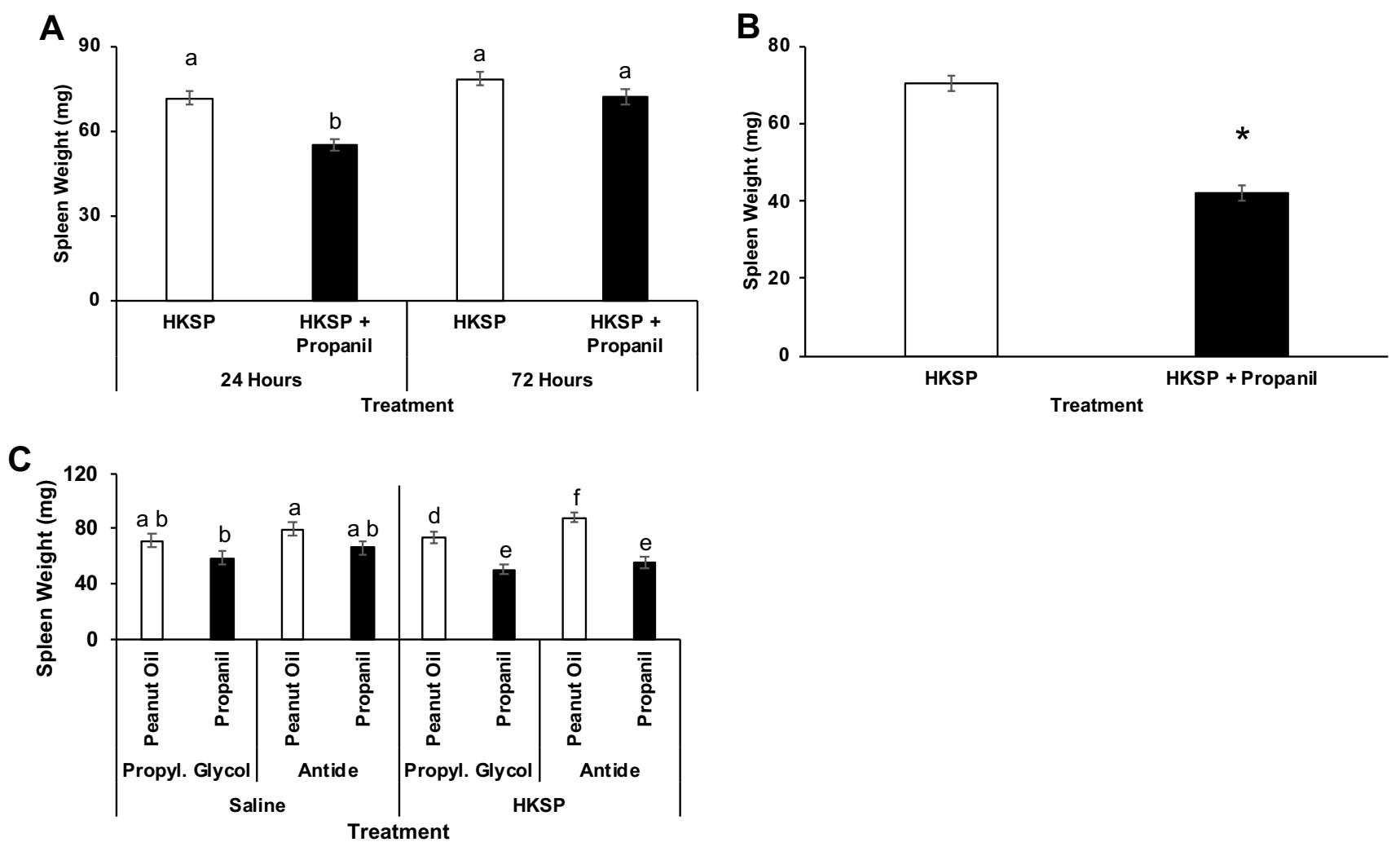

Figure 4. Spleen weights post-HKSP immunization + /- propanil and antide

exposure. Whole spleens were weighed in grams then converted into milligrams. Trial 1 (A) included 24 and 72 hours, while trial 2 (B) only included 24 hours, and trial 3 (C) included 24 hours, and the mice were treated with $+/$ - antide. Data were analyzed by two-way ANOVA followed by Tukey-HSD for (A) and (C, within Saline or HKSP group) and by t-test $(B)$. Interaction of treatment and time (A) was detected. Statistical differences are denoted by different letters for trial $1(A)$ and * represents $p \leq 0.05$ for trial 2 (B). Statistical differences in $\mathrm{C}$ are also denoted by different letters (saline treatment a-c and HKSP treatment d-f). Group means (bars) that do not share the same letter within the group (saline or HKSP) differ from each other. For example, within saline (left $1 / 2$ of the graph C) group $\mathbf{b}$ differs from the group with $\mathbf{a}$, but neither $\mathbf{a b}$ is different from a, nor it is different from $\mathbf{b}$. Within HKSP (right $1 / 2$ of the graph $\mathrm{C}$ ), $\mathbf{d}$ is 
different from either $\mathbf{e}, \mathbf{d}$ is different from $\mathbf{f}, \mathbf{e}$ is different from $\mathbf{f}$, but the two $\mathbf{e}$ groups are not statistically different from each other. 

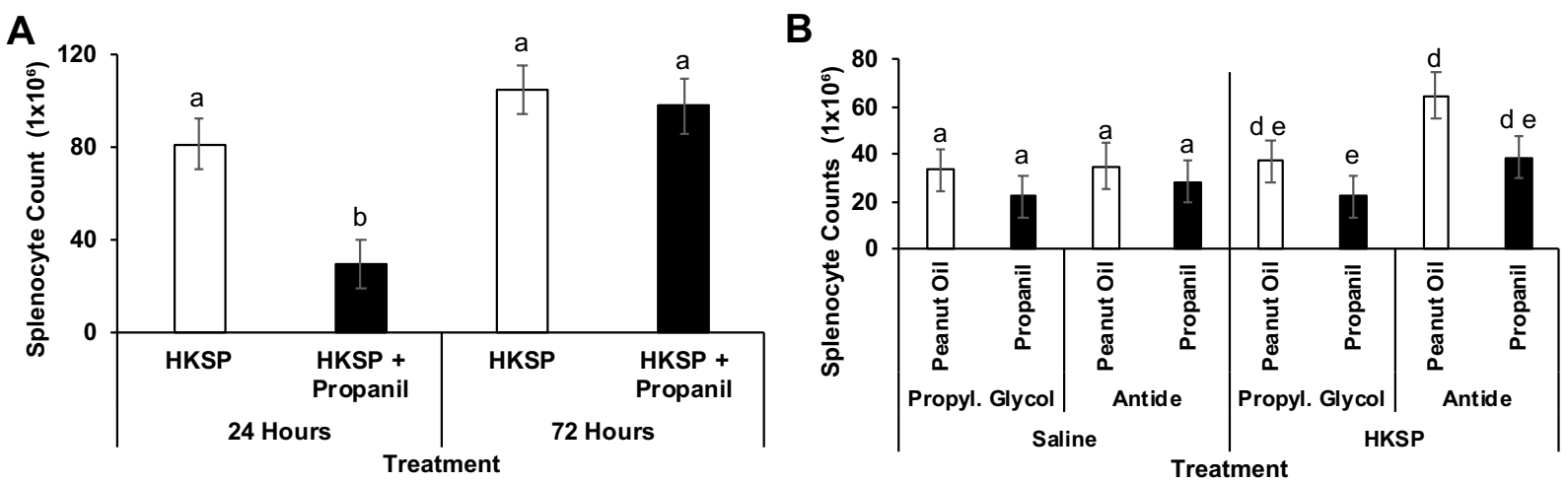

Figure 5. The total number of splenocytes post-HKSP immunization $+/$ - propanil exposure. Trial 1 (A) included 24 and 72 hours, and trial 3 (B) only included 24 hours, and the mice were treated with $+/$ - antide. The spleen was removed from mice and processed into a single cell suspension. After lysis of RBC, leukocytes were counted on a hemocytometer using trypan blue exclusion. Data were analyzed by two-way ANOVA, followed by Tukey-HSD. Statistical differences are denoted by different letters trial 1 (ab) and trial 3 (saline treatment a-c and HKSP treatment d-f). Group means (bars) that do not share the same letter within the group (saline or HKSP) differ from each other. 

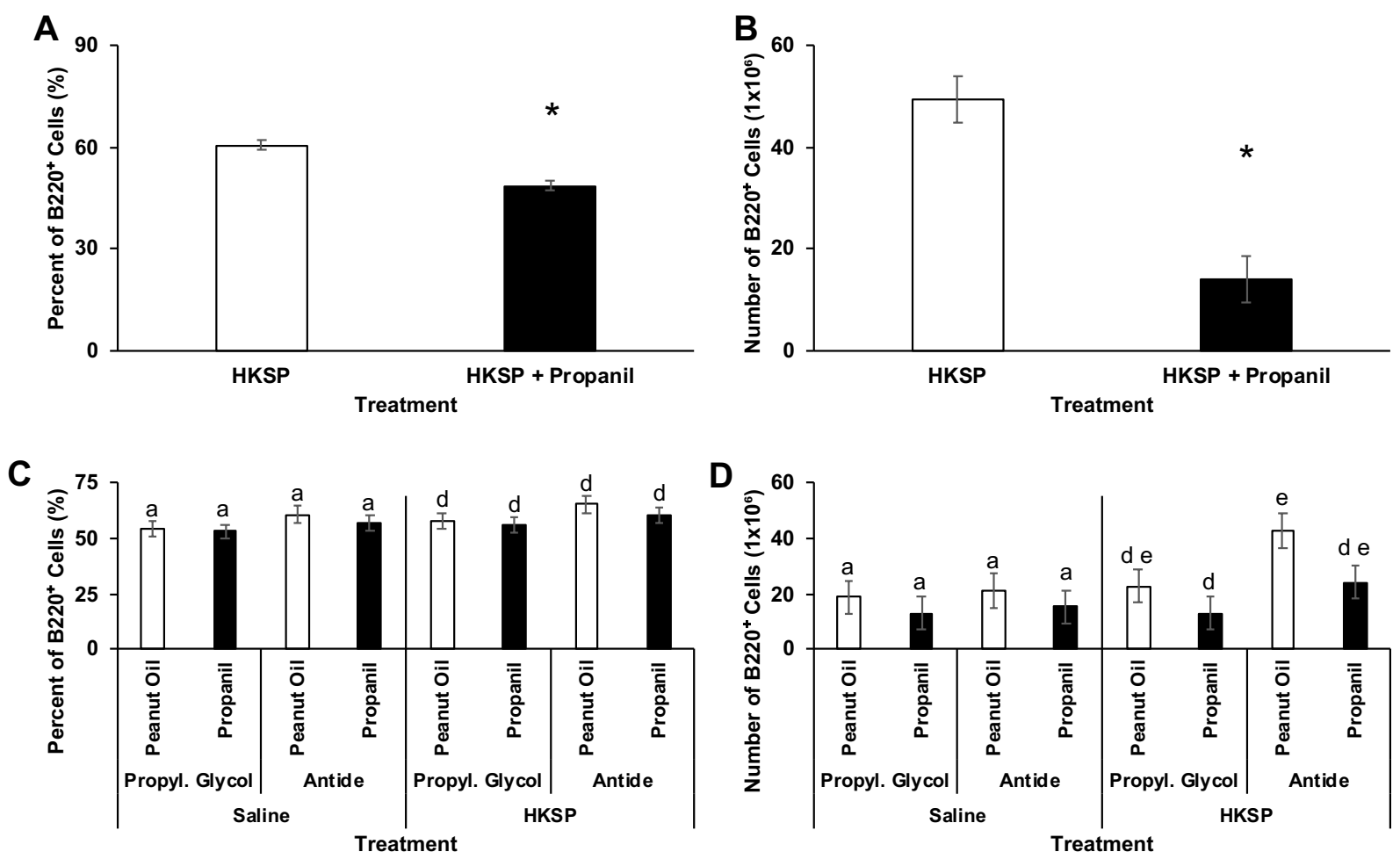

Figure 6. Percentage and the total number of B cells in the spleen 24 hours postHKSP immunization +/- propanil exposure. The B cell populations from trial 1 (A and $B)$ and trial $3(C$ and $D)$. Isolated splenocytes were analyzed by flow cytometry $(A, C)$. The total number of cells was multiplied by the percent of cells determined by flow cytometry (B, D). For trial 1 the data were analyzed by one-way ANOVA ( $\left.{ }^{*} p \leq 0.05\right)$ and trial 3; the data were analyzed by two-way ANOVA followed by Tukey-HSD. Statistical differences are denoted by different letters (saline treatment a-c and HKSP treatment df). Group means (bars) that do not share the same letter within the group (saline or HKSP) differ from each other. 

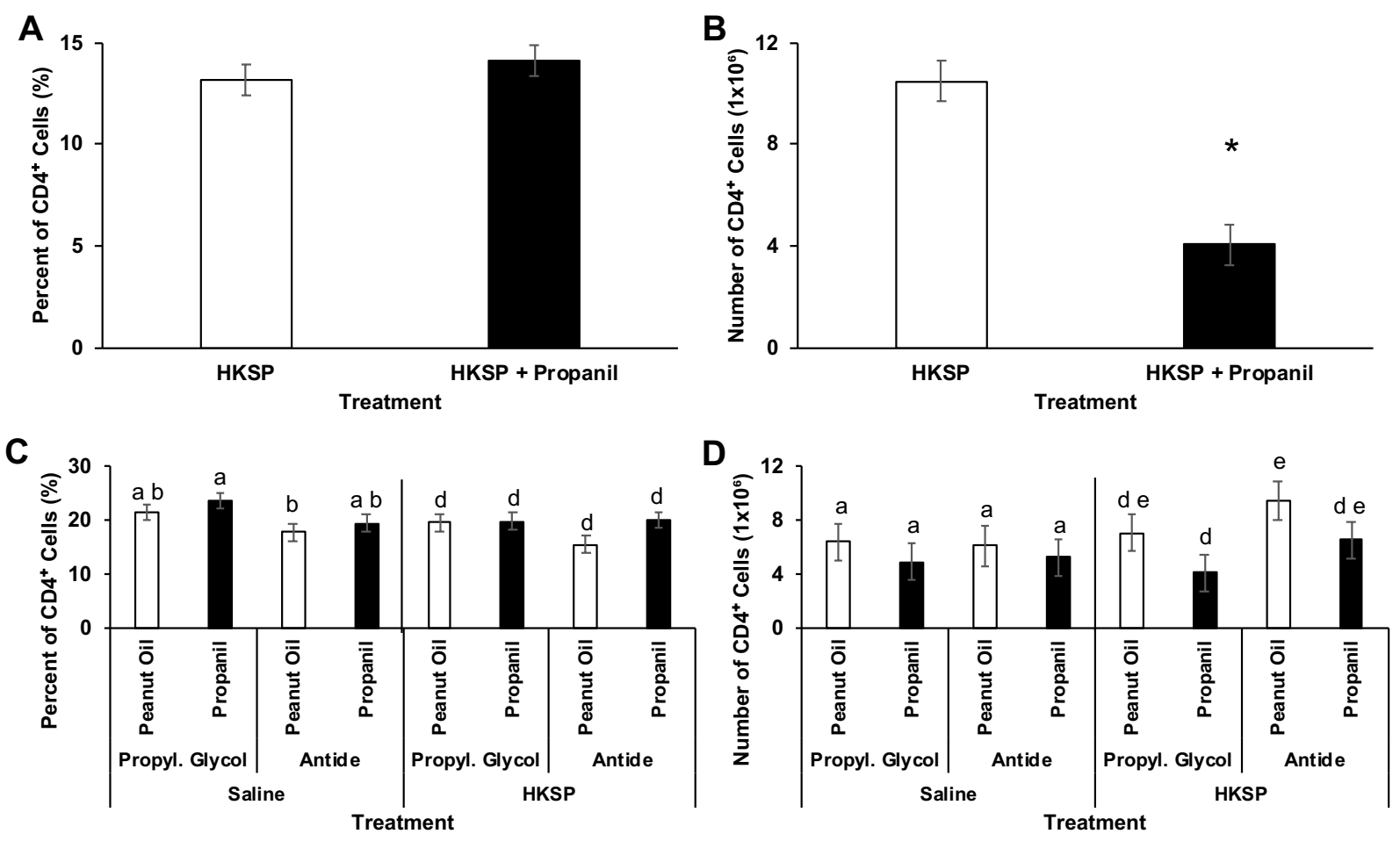

Figure 7. Percentage and the total number of $C D 4^{+} \mathrm{T}$ cells in the spleen 24 hours post-HKSP immunization +/- propanil exposure. The $\mathrm{CD} 4^{+} \mathrm{T}$ cell populations from trial $1(A$ and $B)$ and trial $3(C$ and $D)$. Isolated splenocytes were analyzed by flow cytometry $(A, C)$. The total number of cells was multiplied by the percent of cells determined by flow cytometry (B, D). For trial 1 the data were analyzed by one-way ANOVA ( $\left.{ }^{*} p \leq 0.05\right)$ and trial 3 ; the data were analyzed by two-way ANOVA followed by Tukey-HSD. Statistical differences are denoted by different letters (saline treatment a-c and HKSP treatment d-f). Group means (bars) that do not share the same letter within the group (saline or HKSP) differ from each other. 

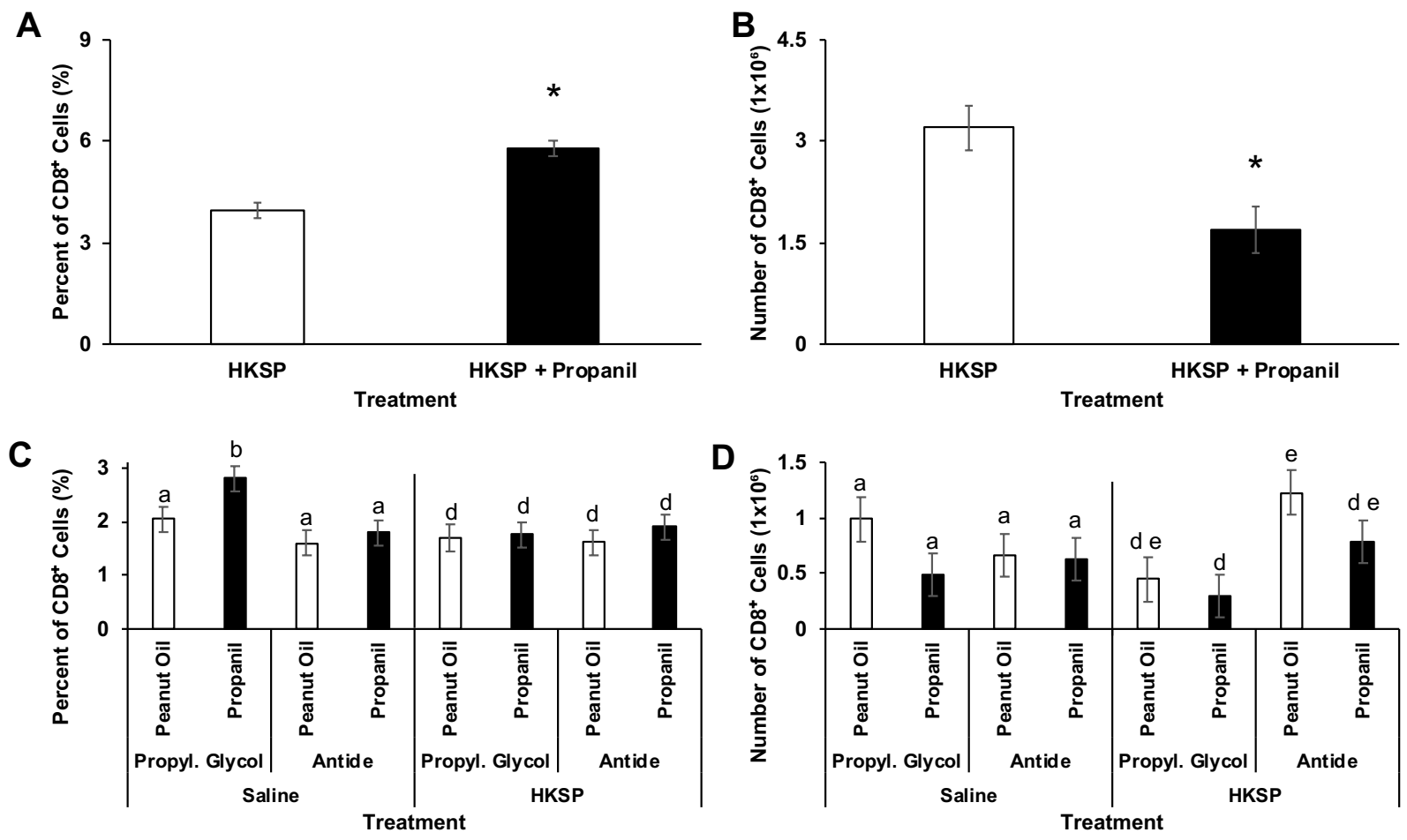

Figure 8. Percentage and the total number of $C D 8^{+} T$ cells in the spleen 24 hours post-HKSP immunization +/- propanil exposure. The CD8 ${ }^{+} T$ cell populations from trial $1(A$ and $B$ ) and trial $3(C$ and $D)$. Isolated splenocytes were analyzed by flow cytometry $(A, C)$. The total number of cells was multiplied by the percent of cells determined by flow cytometry (B, D). For trial 1 the data were analyzed by one-way ANOVA ( $\left.{ }^{*} p \leq 0.05\right)$ and trial 3 ; the data were analyzed by two-way ANOVA followed by Tukey-HSD. Statistical differences are denoted by different letters (saline treatment a-c and HKSP treatment d-f). Group means (bars) that do not share the same letter within the group (saline or HKSP) differ from each other. 

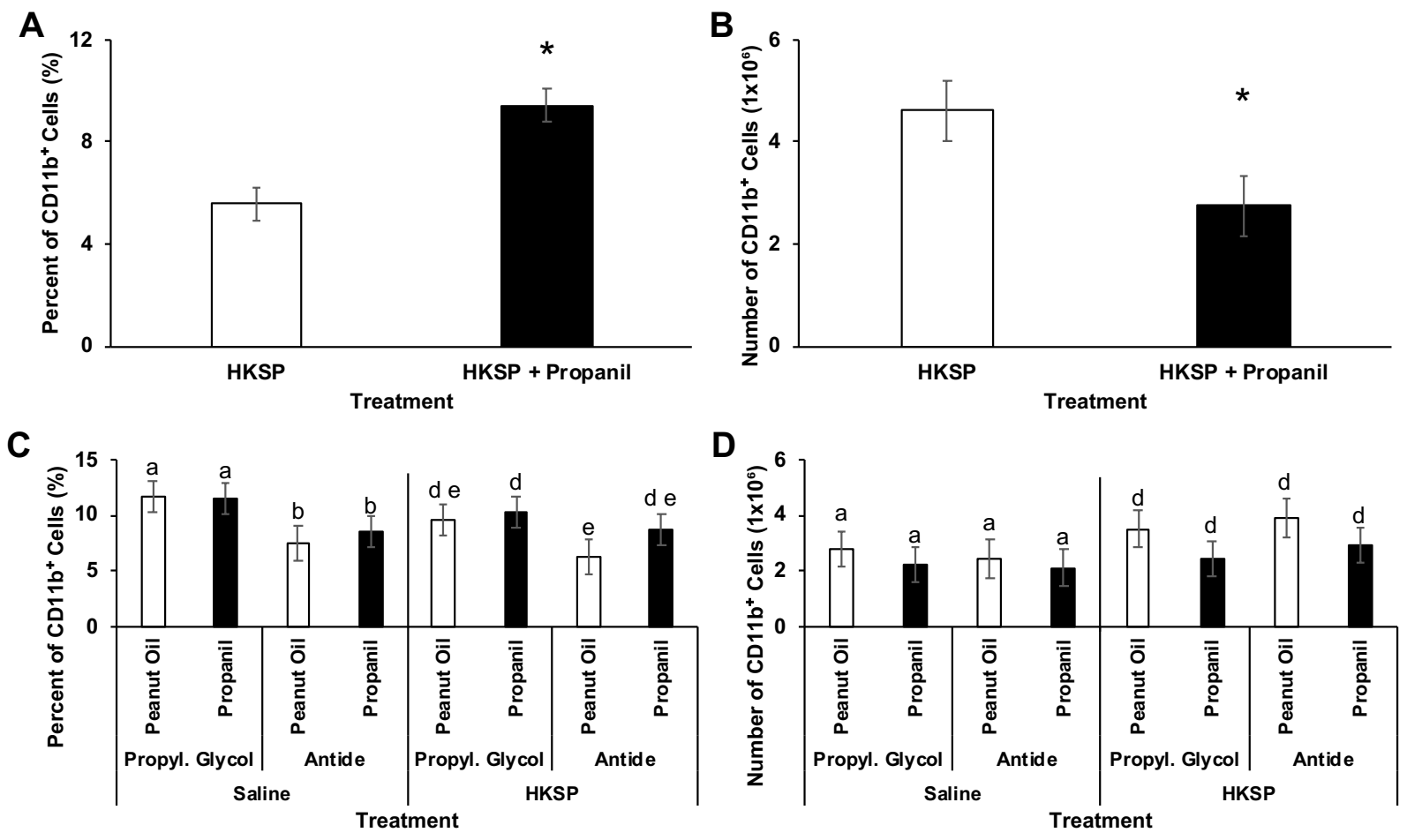

Figure 9. Percentage and the total number of $C D 11 b^{+} T$ cells in the spleen 24 hours post-HKSP immunization $+/$ - propanil exposure. The CD11 $\mathrm{b}^{+} \mathrm{T}$ cell populations from trial $1(A$ and $B)$ and trial $3(C$ and $D)$. Isolated splenocytes were analyzed by flow cytometry (A, C). The total number of cells was multiplied by the percent of cells determined by flow cytometry $(B, D)$. Data were analyzed by two-way ANOVA, followed by Tukey-HSD. Statistical differences are denoted by different letters trial 1 (a-d) and trial 3 (saline treatment a-c and HKSP treatment d-f). Group means (bars) that do not share the same letter within the group (saline or HKSP) differ from each other. 

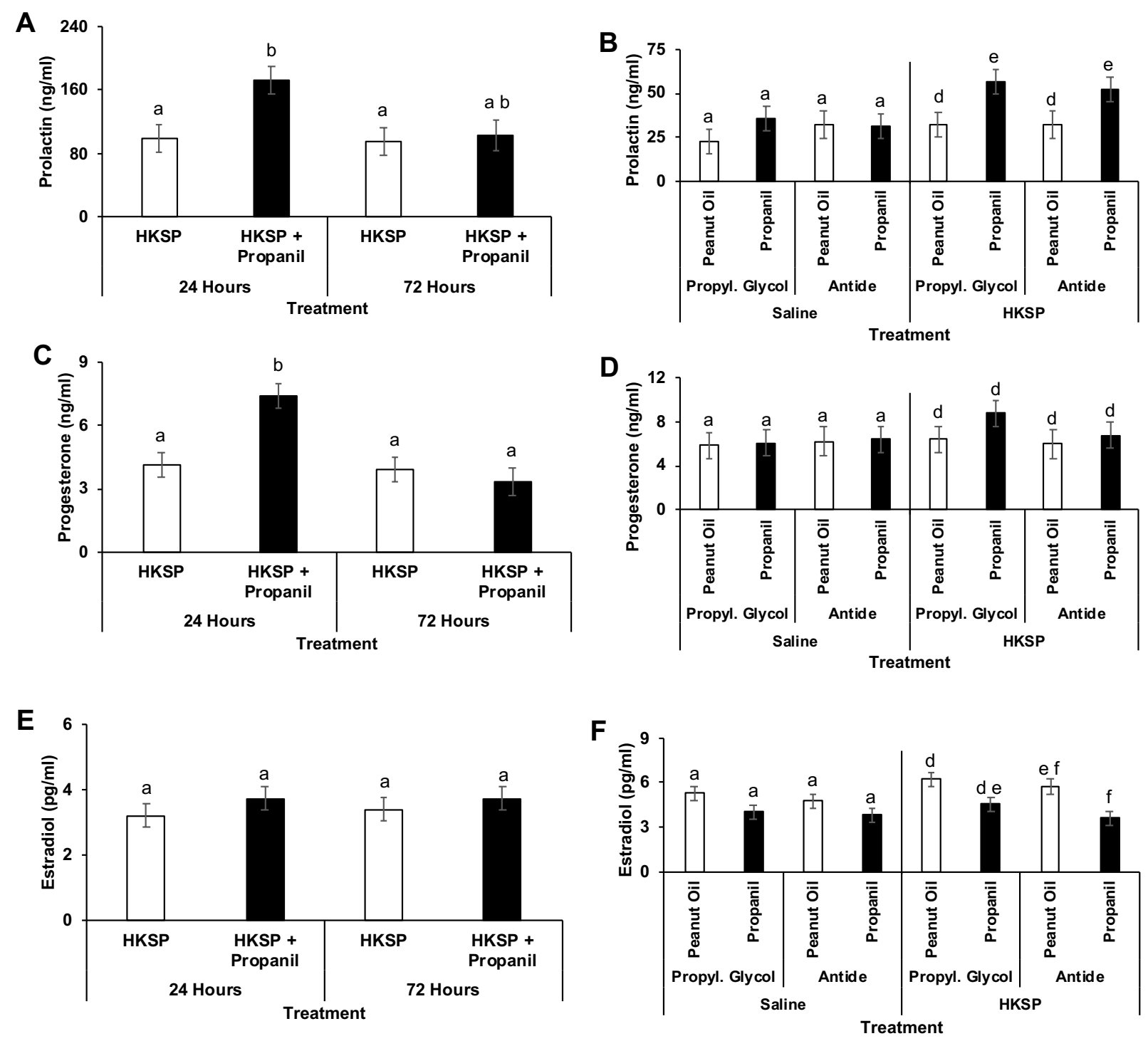

Figure 10. Serum hormone concentrations post-HKSP immunization +/- propanil exposure. Trial 1 represents graphs $A, C, E$, and trial 3 represents graphs $B, D, F$. the tree hormone measured included prolactin $(A, B)$, progesterone $(C, D)$, and estradiol $(E$, F) at twenty-four hours after exposure. Data were analyzed by two-way ANOVA, followed by Tukey-HSD. Statistical differences are denoted by different letters trial 1 (ad) and trial 3 (saline treatment a-c and HKSP treatment d-f). Group means (bars) that do not share the same letter within the group (saline or HKSP) differ from each other. 

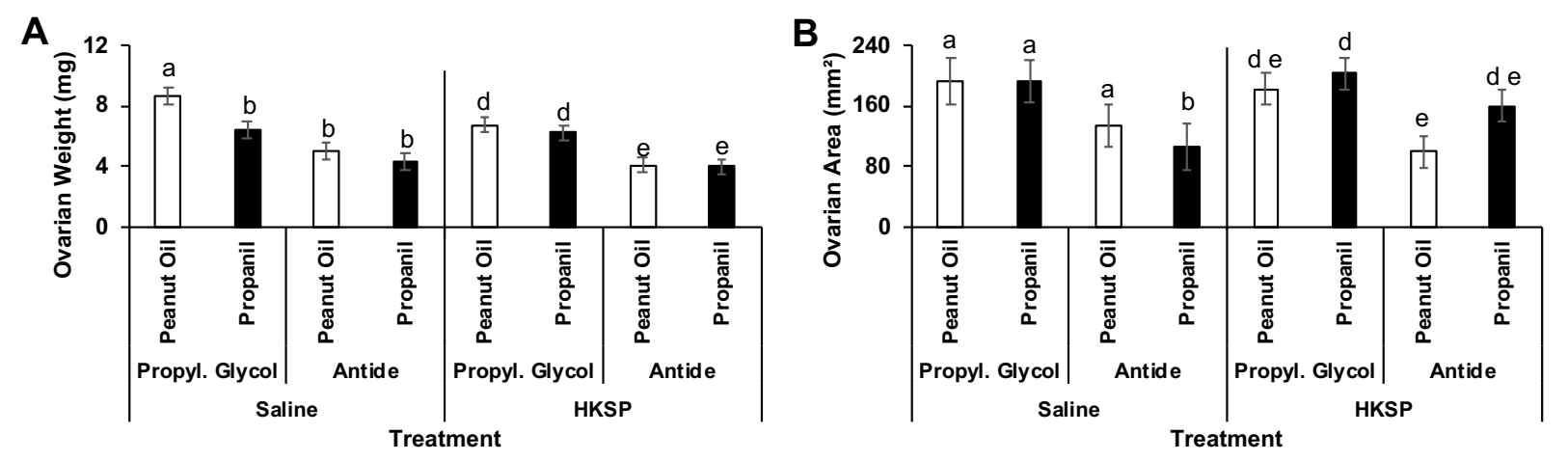

Figure 11. Effect of propanil and antide exposure in +/- HKSP immunization on ovarian weights and ovarian area. The whole ovaries $(A)$ were weighed. Ovarian area (B) was measured with ImageJ from sections stained with H\&E. Data were analyzed by two-way ANOVA, followed by Tukey-HSD. Statistical differences are denoted by different letters (saline treatment a-c and HKSP treatment d-f). Group means (bars) that do not share the same letter within the group (saline or HKSP) differ from each other. 


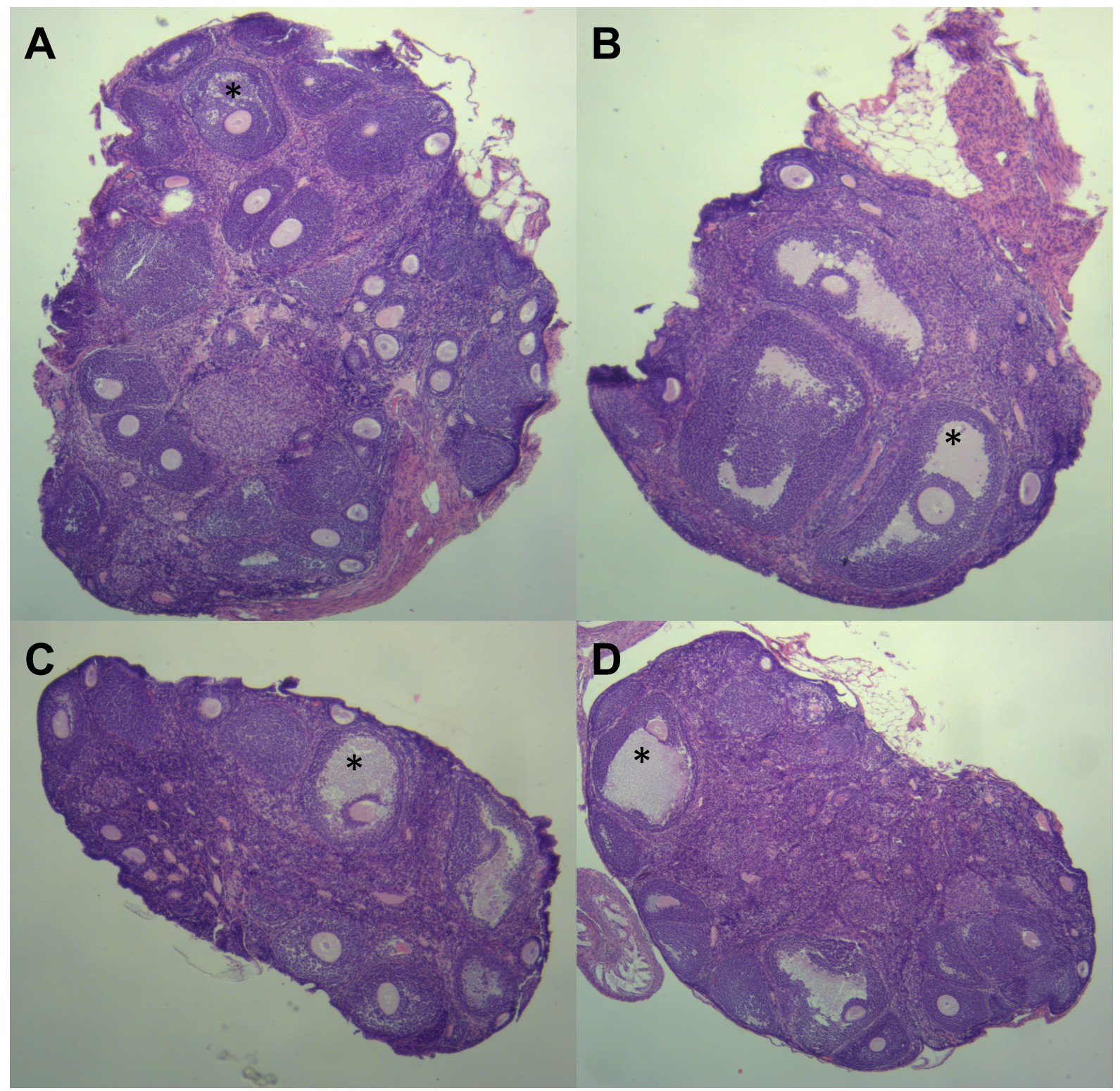

Figure 12. Ovarian histology after mice received six doses of antide. Antide effect on ovarian area represented by histology mice treated with propylene glycol, peanut oil, and $\operatorname{HKSP}(A)$, mice treated with propylene glycol, propanil, and HKSP $(B)$, mice treated with antide, peanut oil, and HKSP (C), and mice treated with antide, propanil, and HKSP (D) twenty-four hours after exposure to propanil. 


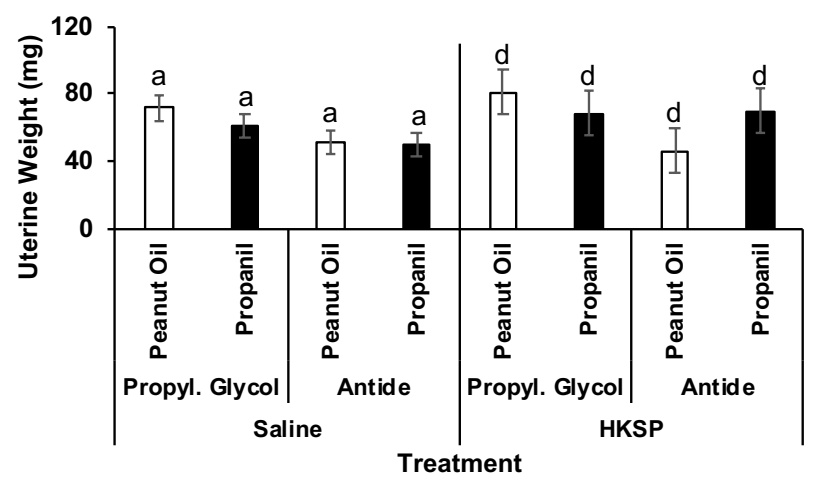

Figure 13. Propanil and antide exposures on uterine weights +/- HKSP

immunization. The whole uterus was weighed. Data were analyzed by two-way ANOVA, followed by Tukey-HSD. Statistical differences are denoted by different letters (saline treatment a-c and HKSP treatment d-f). No statistical differences were detected in multiple comparisons in uterine weight. 

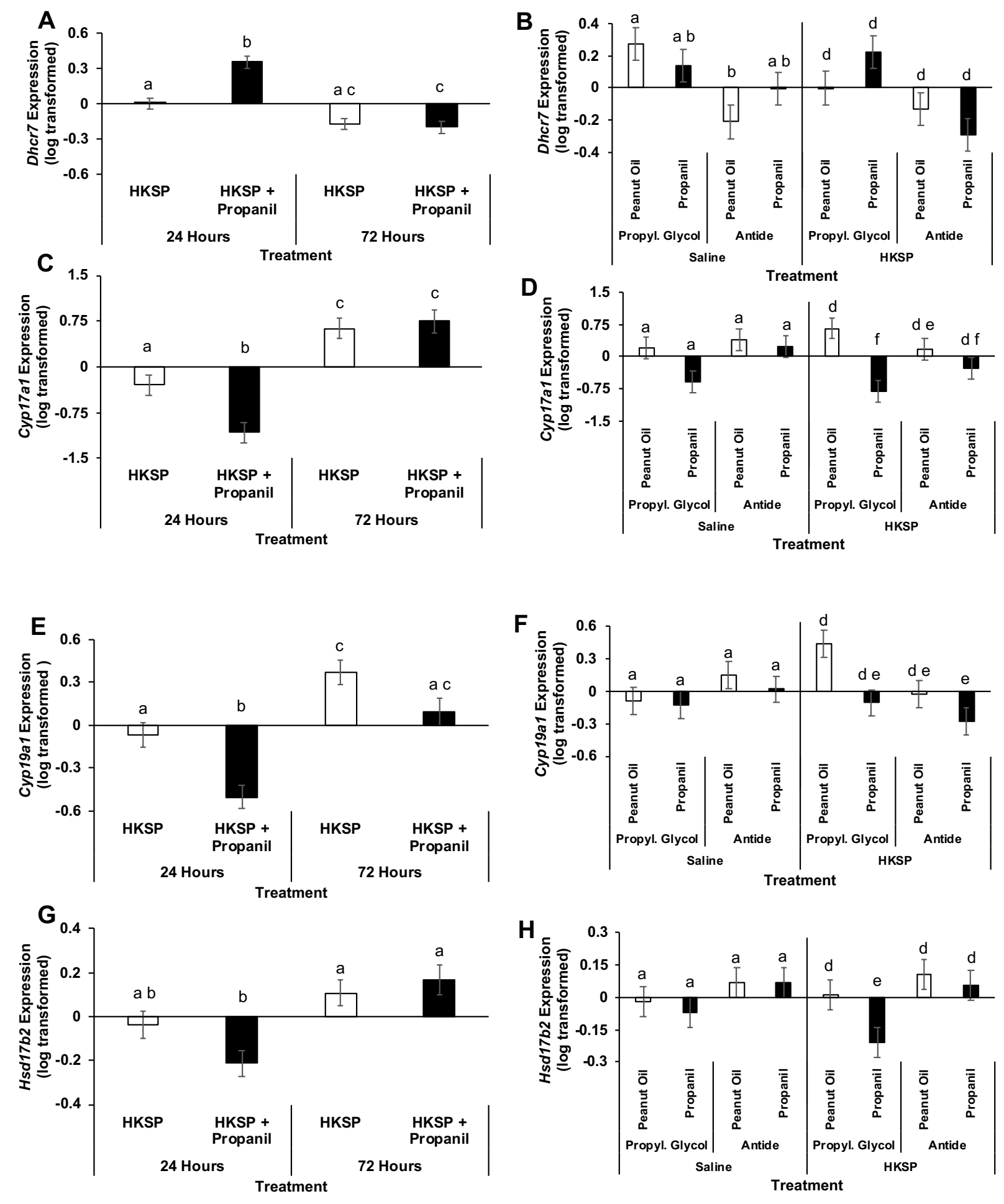


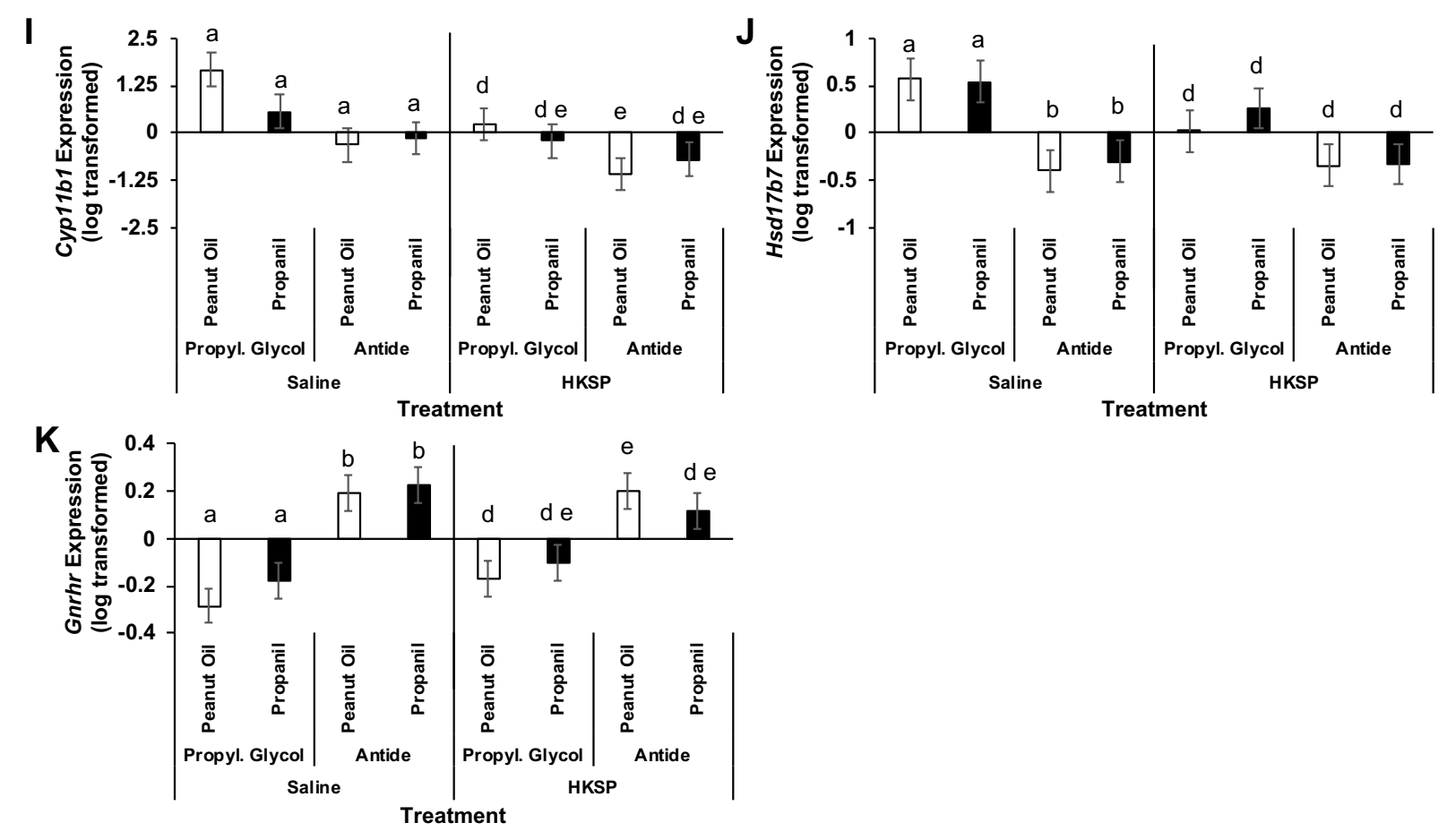

Figure 14. Expression of steroid synthesis enzymes and Gnrhr post-HKSP

immunization +/- propanil exposure. The expression of genes was log-transformed after being normalized to the two housekeeping genes (Hprt1 and Actb). Significantly different expression was observed in Dhcr7 (A, B), Cyp17a1 (C, D), Cyp19a1 (E, F) and Hsd17b2 (G, H), Cyp11b1 (I), Hsd17b7 (J) and Gnrhr (K), a gene involved in steroid hormone synthesis except for Gnrhr. Trial 1 (A, C, E, G) and Trial 3 (B, D, F, H, I, J, and K). Data were analyzed by two-way ANOVA, followed by Tukey-HSD. Statistical differences are denoted by different letters trial $1(a-d)$ and trial 3 (saline treatment a-c and HKSP treatment d-f). Group means (bars) that do not share the same letter within the group (saline or HKSP) differ from each other. 

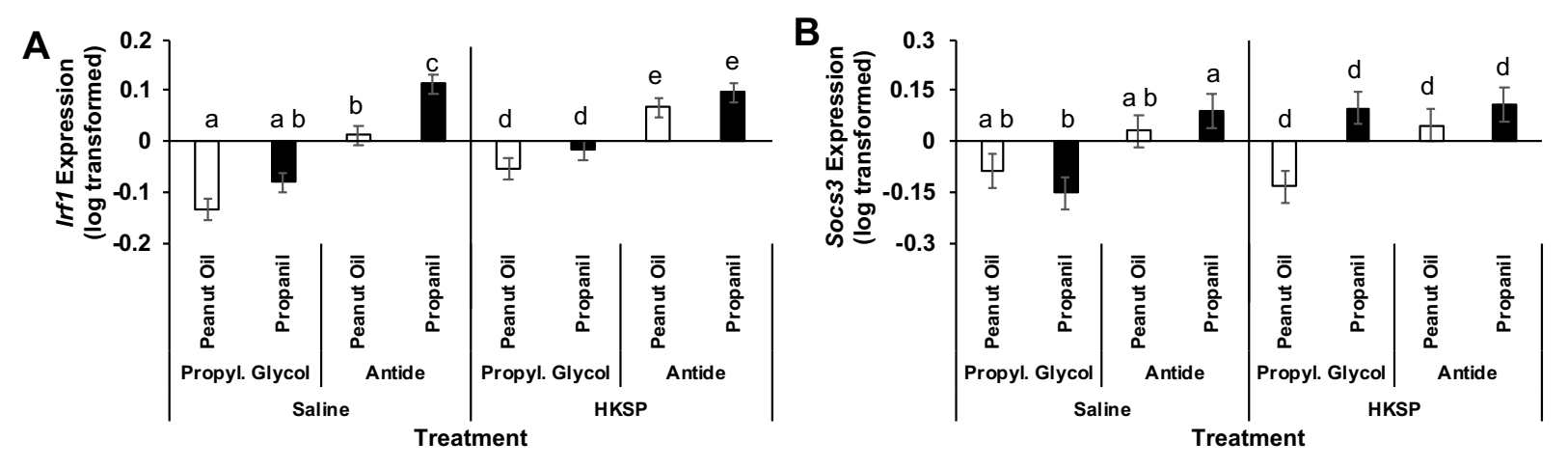

Figure 15. Expression at 24 hours post-exposure of genes involved in prolactin

synthesis. The gene was normalized to two housekeeping genes (Hprt1 and Actb). The Irf1 (A) and Socs3 (B) are involved in the Prolactin synthesis pathway. Data were analyzed by two-way ANOVA, followed by Tukey-HSD. Statistical differences are denoted by different letters (saline treatment a-c and HKSP treatment d-f). Group means (bars) that do not share the same letter within the group (saline or HKSP) differ from each other. 


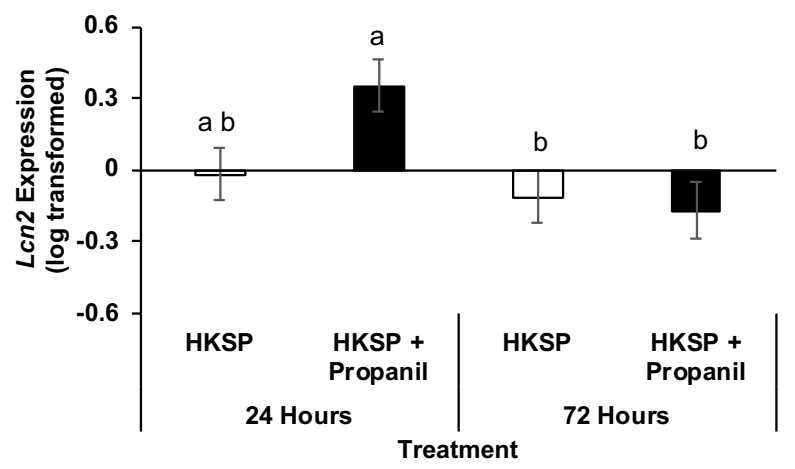

Figure 16. Expression at 24 hours post-exposure of Lcn2. The gene was normalized to two housekeeping genes (Hprt1 and Actb). Data were analyzed by twoway ANOVA, followed by Tukey-HSD. Statistical differences are denoted by different letters. Group means (bars) that do not share the same letter differ from each other. 

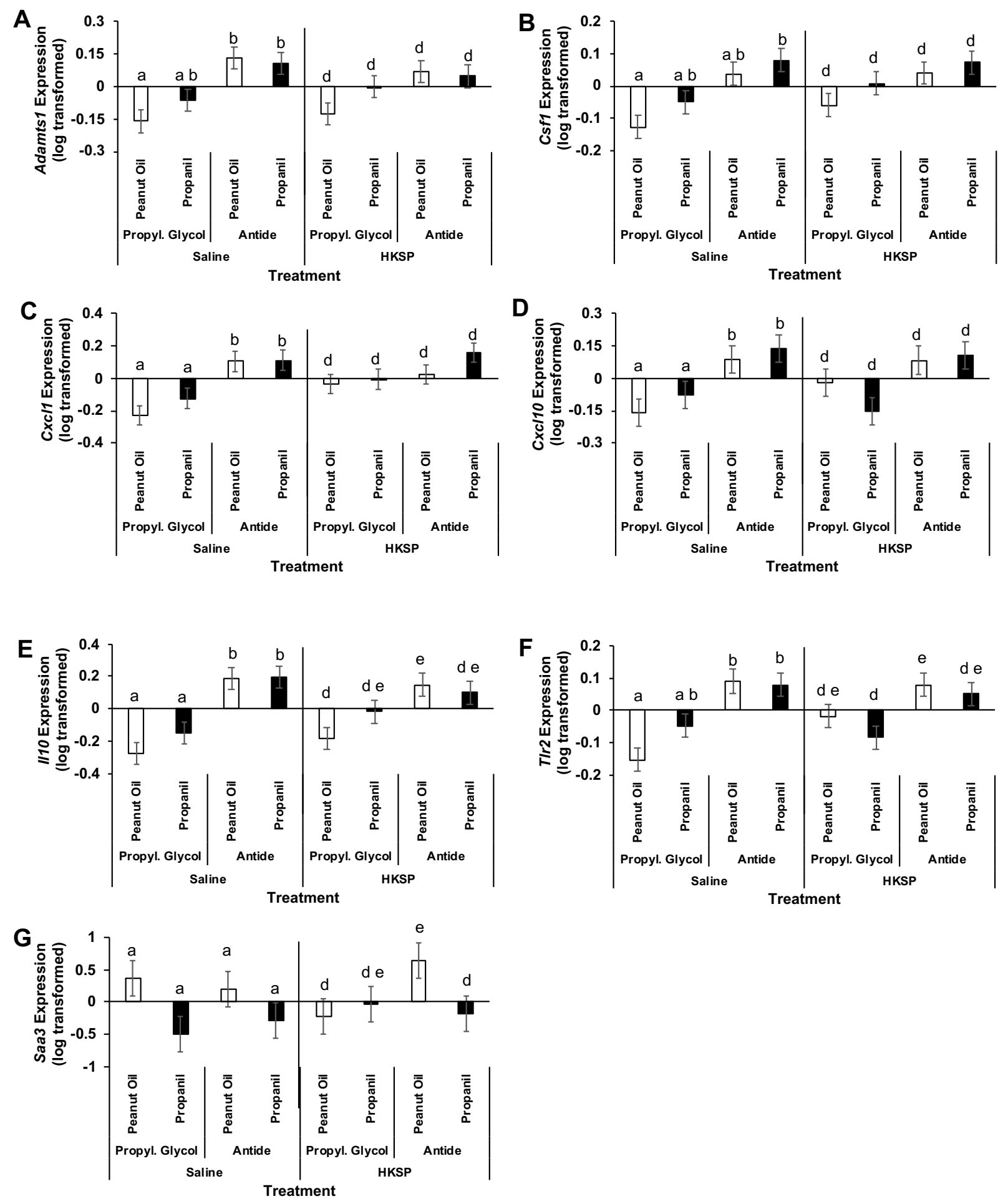

Figure 17. Expression at 24 hours post-exposure of genes involved in extracellular matrix remodeling and immune regulation. The gene was normalized to two housekeeping genes (Hprt1 and Actb). The Adamts1 (A), Csf1 (B), Cxcl1 (C), 
Cxcl10 (D), II10 (E), TIr2 (F) and Saa3 (G) are involved in the immune system regulation. Data were analyzed by two-way ANOVA, followed by Tukey-HSD. Statistical differences are denoted by different letters (saline treatment a-c and HKSP treatment $d$ f). Group means (bars) that do not share the same letter within the group (saline or HKSP) differ from each other. 


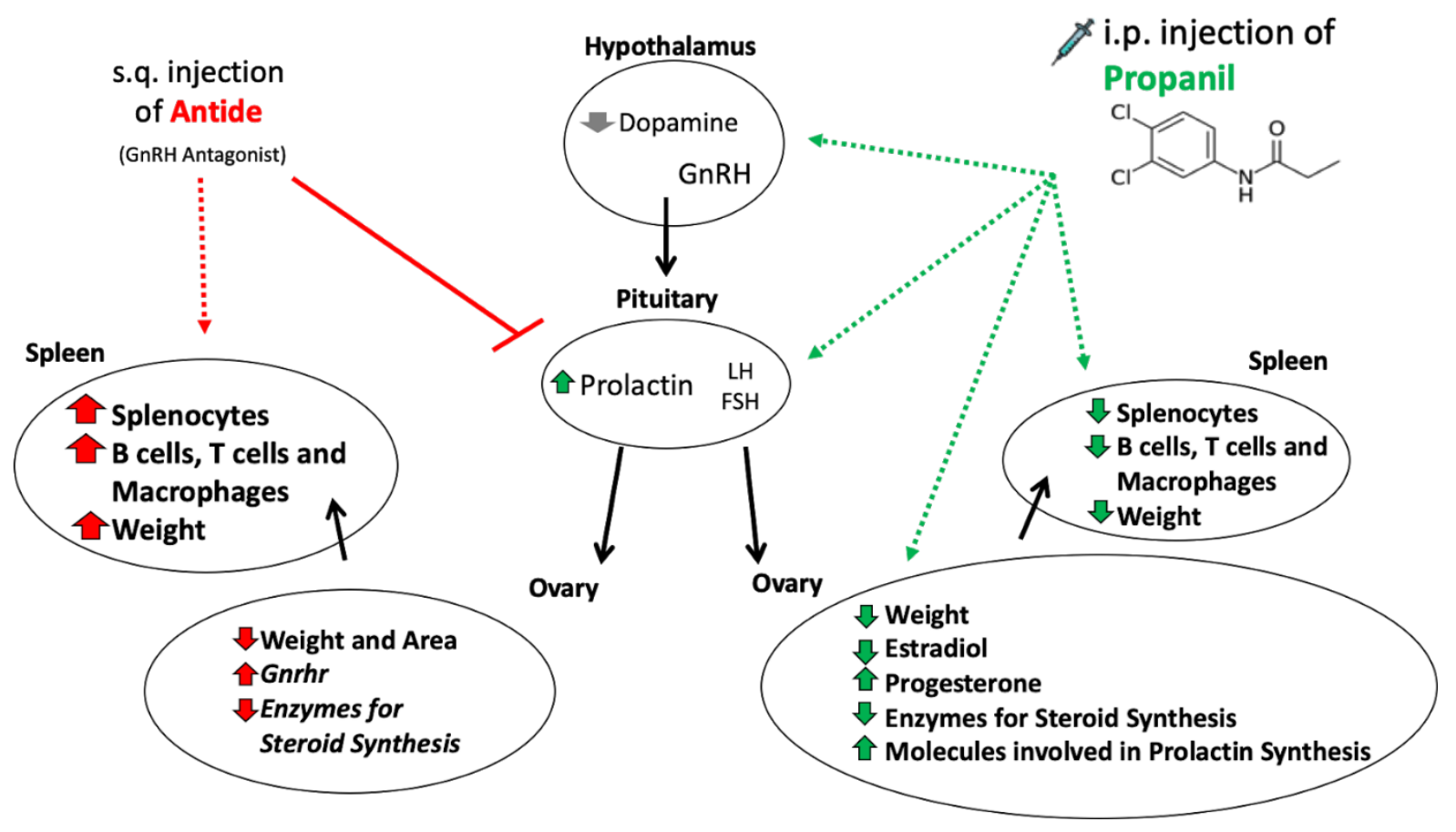

Figure 18. Proposed model for acute propanil-mediated effects on the HPG axis leading to immunomodulation. The red arrows with a black outline are representing the antide effect. Green arrows with black outlines represent the propanil effect. The dotted arrows are showing where antide (red) and propanil (green) may be acting on the HPG axis. The black arrows represent the HPG axis and the proper pathway of the HPG axis. 


\section{Chapter 5: Discussion}

These studies aimed to determine the acute effect of propanil in female mice immunized with HKSP at 24 and 72 hours after exposure on splenic cell populations, reproductive hormones, and ovarian and oviductal gene expression. Propanil had an acute effect, mostly in 24 hours, on spleen weight, splenocytes, number and percent of splenic cell populations, reproductive hormones, and steroid synthesis genes. Another goal was to examine if $\mathrm{GnRH}$ antagonist (antide) interfered with propanil's acute response since $\mathrm{GnRH}$ receptors have been found on the spleen in the rat (Jacobson et al., 1998) and ovaries in mice (Torrealday et al., 2013). Also, antide abrogated the PCspecific, ASC response on day 7 in propanil-treated, HKSP-challenged mice (Salazar et al., 2006). Antide bound to the $\mathrm{GnRH}$ receptors, as evidenced by the decrease in ovarian weight, ovarian area, and uterine weight. GnRH may induce signals not only through the pituitary gland via the HPG axis but bind directly in the ovary.

The spleen weight and the number of splenic cells decreased at 24 hours after propanil. The spleen weight and total splenocyte counts in our study were back to normal at 72 hours. In contrast, a dramatic increase in spleen size, up to 17 times larger spleen, occurred seven days after propanil and HKSP exposure (Barnett and Gandy, 1989; Barnett et al., 1992; Salazar et al., 2005). The enlargement on day 7 may be partially explained by induced clonal expansion in antibody production by B cells due to HKSP, which is not occurring as early as 24 or 72 hours, and partially by propanil. These conflicting results may indicate propanil involvement in two different processes: innate immune system inflammation/anti-inflammatory process in 24 hours versus 
adaptive immune response on day 7 . Alternatively, extramedullary hematopoiesis in the spleen could occur (Barnett et al., 1992). Another possibility is the migration of cells to the spleen or a direct mitogenic effect of propanil on splenocytes (Barnett et al., 1992), or it could be due to hemoglobinemia or hemolytic anemia. The decrease in spleen weight and splenocyte count is not fully understood or why this occurs at 24 hours then increases to the same level as the control at 72 hours.

Why the percent of specific cell populations increased $\left(C D 8^{+}\right.$and $\left.C D 11 b^{+}\right)$while the percent and numbers of B cells decreased are not known. The decrease in total splenic cell number after propanil reflected decreases in the specific cell populations at 24 hours. The decrease in the B-cells due to propanil, however, was still observed in antide-HKSP-propanil treated mice, but antide increased the number of B-cells to double in peanut oil controls $\left(40 \times 10^{6}\right.$ vs. $20 \times 10^{6}$, Figure $\left.6 \mathrm{D}\right)$. Thus, either B-cells have $\mathrm{GnRH}$ receptors and are directly affected by antide or affected indirectly via another mediator. Decreased immune cell population induced by propanil exposure may result in leukocytes being released from the spleen and going to the ovary or other specific organs to assist in the propanil mediated response. Possible candidate organs may be the liver and kidneys as these organs were enlarged in acute response to propanil (Ambrose et al., 1972; Valentovic et al., 1997; Cakici and Akat, 2013).

Antide blocked propanil response on the number of ASC on day 7 using a similar (HKSP + propanil) model (Salazar et al., 2006). Thus, it indicated the importance of the HPG axis in this system. In the spleen at 24 hours, we observed the effect of antide on percent and the number of $\mathrm{CD}^{+}$cells. Specifically, antide without HKSP decreased the percent of $\mathrm{CD}^{+}$cells, while in HKSP challenged animals, antide doubled the number of 
$\mathrm{CD}^{+}$cells (from a 0.5 to $1 \times 10^{6}$ per spleen). It is uncertain what is the connection between antide and CD8+ cells in the spleen without knowing if $\mathrm{CD} 8^{+}$cells contain the $\mathrm{GnRH}$ receptors. Human healthy and leukemic T-cells produce two isoforms of $\mathrm{GnRH}$ : I and II (Chen et al., 2002). Those authors suggested that the GnRH-I and II act in an autocrine or paracrine fashion to trigger laminin receptor gene transcription, adhesion, and chemotaxis of T-cells. Our results with $\mathrm{CD} 8^{+} \mathrm{T}$-cells support the finding that antide disrupts the effect of propanil exposure in mice. We can conclude that at both 24 hours and 7 days post-exposure to propanil, antide modifies propanil response (albeit different response) in the spleen.

In 2006 Salazar showed that if the ovaries were removed, the increase in ASC did not occur; therefore, the propanil must affect the ovaries to mediate an increase in ASC and spleen weight (Salazar et al., 2006). Our results indicate that propanil interferes with steroid synthesis due to the increase in progesterone in the serum. Modified gene expression of enzymes involved in steroid synthesis in ovaries also supports this as we observed decreased changes in 7-dehydrocholesterol reductase (Dhcr7), cytochrome P450 family 11 subfamily B member 1 (Cyp11b1), cytochrome P450 family 19 subfamily A member 1 (Cyp19a1), 17-beta 2-hydroxysteroid dehydrogenase (Hsd17b2), 17-beta 7-hydroxysteroid dehydrogenase (Hsd17b7), and cytochrome P450 family 17 subfamily A member 1 (Cyp17a1). These genes are responsible for producing cholesterol, cortisol, estradiol, testosterone, and 17-hydroxy pregnenolone.

Because DHCR7 converts 7-dehydrocholesterol into cholesterol, an increase in this enzyme would allow more cholesterol for steroid synthesis. CYP11B1 converts 
deoxycorticosterone into corticosterone and 11-deoxycortisol into cortisol; a decrease in this enzyme would prevent the synthesis of corticosterone and cortisol. Cyp11b1 expression decreased in the ovaries due to antide regardless of propanil exposure. Therefore, $\mathrm{GnRH}$ receptors may not mediate the effect of propanil at 24 hours. The $\mathrm{GnRH}$ receptor may ensure compartmentalization of steroid synthesis in the ovary to focus on testosterone, estrogens, and progestins.

The enzyme CYP17A1 converts pregnenolone into 17-hydroxy pregnenolone then to dehydroepiandrosterone. If the gene expression is reduced, the synthesis of those steroids are lower, and pregnenolone is available as a substrate for progesterone. Thus, progesterone production should increase as observed. In parallel, CYP17A1 converts progesterone to 17-hydroxyprogesterone and further to androstenedione, which is a substrate for estrone and testosterone. A consequence of decreased Cyp17a1 may be reduced substrate for testosterone and estradiol and accumulation of progesterone, further supporting the increased progesterone results. Increased synthesis of progesterone can lead not only to effects on reproductive or immune tissues but also could serve as a reservoir for corticosterone, a substrate for cortisol, or to the major mineralocorticoid - aldosterone, involved in stress and renal function, respectively. Data in mice and eels also demonstrated an increase in corticosterone and cortisol respectively after treated with propanil (Cuff et al., 1996; Pruett et al., 2000; de la Rosa et al., 2005; Sancho et al., 2017).

The enzyme CYP19A1 (aromatase) is responsible for converting androstenedione into estrone and testosterone into estradiol by adding a hydrogen ion to oxygen for a hydroxy group. The decrease of Cyp19a1 observed due to propanil in 
24 hours in our study should lead to a decrease in estradiol, which occurred in trial 2 , but not in trials 1 and 3 . In trial 1 , the estradiol levels did not change, and that could be due to the sensitivity of the assay.

HSD17B7 converts estrone into estradiol. The reduction in Hsd17b7, as well as Dhcr7, supports the decrease observed in estradiol concentrations in serum. HSD17B2 is an enzyme that converts estradiol into estrone by removing a hydrogen ion. The decrease in Hsd17b2 should prevent the conversation of estradiol to estrone; therefore, an accumulation of estradiol, which could inhibit $\mathrm{GnRH}$ via negative feedback.

In the ovaries, antide alone increased the amount of Grnhr mRNA in saline and HKSP treated mice. Therefore, we can conclude that antide blocked $\mathrm{GnRH}$ binding the $\mathrm{GnRH}$ receptor. Thus, $\mathrm{GnRH}$ may act directly on the ovary. $\mathrm{GnRH}$ receptor has been detected in mouse ovaries, specifically in granulosa cells by immunohistochemistry (Singh et al., 2011). Even though we observed the strong stimulatory effect on Gnrhr expression in the ovaries, this effect happened regardless of propanil or HKSP exposure; therefore, it does not mediate the effect of propanil at 24 hours.

Because propanil did not affect any studied gene expression on the oviduct, propanil may be acting on the ovary only and not the oviduct in the female mice. Propanil is acting as an endocrine disruptor to decrease enzymes that are responsible for producing steroid hormones important to reproduction.

Antide induced pro-inflammatory cytokines and other immune molecules, independently of an immune challenge with HKSP. Hence, the increase in inflammatory cytokines could be mimicking an infection, inflammation, or ovulation in the ovary when 
antagonist blocked $\mathrm{GnRH}$ receptors was suggested that $\mathrm{GnRH}$ exerts direct actions at the level of the immune cells (Jacobson et al., 1998). It was reported earlier that $\mathrm{GnRH}$ resembles a cytokine with immunostimulatory action on IL-2 receptor in ex vivo splenocytes and thymocytes from female rats (Batticane et al., 1991). With the increase in the immune molecules, antide is an immune activator and may be acting on more than one organ, including the spleen and ovary. A disintegrin and metalloproteinase with thrombospondin motif 1 (Adamts1), colony-stimulating factor 1 (Csf1), C-X-C motif chemokine ligand $1(\mathrm{CxC} / 1)$, and $\mathrm{C}-\mathrm{X}-\mathrm{C}$ motif chemokine ligand 10 ( $\mathrm{Cxc} / 10)$ and toll-like receptor 2 (TIr2) expression increased in the ovaries after antide regardless of propanil exposure, therefore, $\mathrm{GnRH}$ may not mediate the effect of propanil at 24 hours. While there was a multiple-fold increase in ovarian Saa3 in 24 hours after propanil/HKSP compared to HKSP only detected by microarray analysis (unpublished observations), we did not detect an increase in ovarian Saa3 after propanil with qRT-PCR. The significant interaction between antide and propanil on serum amyloid A3 (Saa3) expression as observed in HKSP-challenged mice, such that there was an upregulation in Saa3 in antide treated group without propanil (peanut oil), compared to propanil group but not in propylene glycol group. The increase in the peanut oil and antidetreated group could be a result of the increase in other pro-inflammatory molecules. More research is needed to understand how these molecules fit into the propanil model.

Figure 18 shows a proposed model for acute propanil-mediated effects on the HPG axis leading to immunomodulation. The different color arrows describe how propanil might act in the female mouse. We do not know if propanil is working directly on the ovaries, but propanil decreased steroid production and influenced splenocyte 
production at 24 hours in intact female mice. The proposed model demonstrates that antide and propanil have different responses within the spleen; therefore, we can suggest that antide is blocking the effect of propanil within the spleen. Antide does not seem to affect the changes made by propanil in the ovary as the trends in steroid synthesis are the same if the animal is exposed to antide and propanil. Therefore, we can conclude that propanil is acting directly on the spleen, but antide is not acting directly on the spleen.

In conclusion, propanil causes an acute effect on spleen weight, splenic cell populations, reproductive hormones, steroid synthesis pathway in mice ovaries. Antagonizing $\mathrm{GnRH}$ with antide affected immune and reproductive variables and modify propanil's acute effect in female mice. Therefore, GnRH may be necessary for the acute phase (24 hours) of propanil/HKSP challenge but may still involve other potential components of the HPG axis. More research is needed to determine where propanil is acting within the female mouse. 


\section{Chapter 6: Literature Cited}

Ambrose AM, Larson PS, Borzelleca JF and Hennigar GR (1972) Toxicologic studies on 3',4'-dichloropropionanilide. Toxicology and Applied Pharmacology 23 650-659.

Antebi E, Lehmann JM, Gingold A and Nobel M (1991) The effect of impairment of blood supply to the rat uterus. International Journal of Fertility 36 376-378.

Bachelot A and Binart N (2007) Reproductive role of prolactin. Reproduction 133361 369.

Barnett JB and Gandy J (1989) Effect of acute propanil exposure on the immune response of C57BI6 mice. Fundamental and Applied Toxicology 12 757-764.

Barnett JB, Gandy J, Wilbourn D and Theus SA (1992) Comparison of the immunotoxicity of propanil and its metabolite, 3,4-dichloroaniline, in C57BI/6 mice. Fundamental and Applied Toxicology: Official Journal of the Society of Toxicology 18 628-631.

Bartha R and Pramer D (1967) Pesticide Transformation to Aniline and Azo Compounds in Soil. Science 156 1617-1618.

Bartha R and Pramer D (1970) Metabolism of Acylanilide Herbicides. In Advances in Applied Microbiology, pp 317-341. Ed D Perlman. Academic Press.

Batticane N, Morale MC, Gallo F, Farinella Z and Marchetti B (1991) Luteinizing hormone-releasing hormone signaling at the lymphocyte involves stimulation of interleukin-2 receptor expression. Endocrinology 129 277-286.

Bauer ER, Meyer HH, Stahlschmidt-Allner P and Sauerwein H (1998) Application of an androgen receptor assay for the characterization of the androgenic or antiandrogenic activity of various phenylurea herbicides and their derivatives. The Analyst 123 2485-2487.

Benjamini Y and Hochberg Y (1995) Controlling the False Discovery Rate: A Practical and Powerful Approach to Multiple Testing. Journal of the Royal Statistical Society. Series B (Methodological) 57 289-300.

Ben-Jonathan N and Hnasko R (2001) Dopamine as a Prolactin (PRL) Inhibitor. Endocrine Reviews 22 724-763.

Bishop CV, Xu F, Molskness TA, Stouffer RL and Hennebold JD (2015) Dynamics of Immune Cell Types Within the Macaque Corpus Luteum During the Menstrual Cycle: Role of Progesterone. Biology of Reproduction 93112.

Blyler G, Landreth KS, Lillis T, Schafer R, Theus SA, Gandy J and Barnett JB (1994) Selective Myelotoxicity of Propanil. Toxicological Sciences 22 505-510. 
Bonney RC and Franks S (1990) The endocrinology of implantation and early pregnancy. Bailliere's Clinical Endocrinology and Metabolism 4 207-231.

Book McAlexander M and Yu-Lee L (2001) Prolactin activation of IRF-1 transcription involves changes in histone acetylation. FEBS Letters 488 91-94.

Brundage KM, Schafer R and Barnett JB (2004) Altered AP-1 (activating protein-1) activity and c-jun activation in T cells exposed to the amide class herbicide 3,4dichloropropionanilide (DCPA). Toxicological Sciences: An Official Journal of the Society of Toxicology 79 98-105.

Cakici O and Akat E (2013) Propanil-induced histopathological changes in the liver and kidney of mice. Analytical and Quantitative Cytopathology and Histopathology 35 163-170.

Chen A, Ganor Y, Rahimipour S, Ben-Aroya N, Koch Y and Levite M (2002) The neuropeptides $\mathrm{GnRH}-\mathrm{Il}$ and $\mathrm{GnRH}-\mathrm{I}$ are produced by human T cells and trigger laminin receptor gene expression, adhesion, chemotaxis and homing to specific organs. Nature Medicine 8 1421-1426.

Chow AYK and Murphy SD (1975) Propanil (3,4-dichloropropionanilide)-induced methemoglobin formation in relation to its metabolism in vitro. Toxicology and Applied Pharmacology 33 14-20.

Clevenger CV, Russell DH, Appasamy PM and Prystowsky MB (1990) Regulation of interleukin 2-driven T-lymphocyte proliferation by prolactin. Proceedings of the National Academy of Sciences 87 6460-6464.

Correale J, Arias M and Gilmore W (1998) Steroid Hormone Regulation of Cytokine Secretion by Proteolipid Protein-Specific CD4+ T Cell Clones Isolated from Multiple Sclerosis Patients and Normal Control Subjects. The Journal of Immunology 161 3365-3374.

Cuff CF, Zhao W, Nukui T, Schafer R and Barnett JB (1996) 3,4-Dichloropropionanilideinduced atrophy of the thymus: mechanisms of toxicity and recovery. Fundamental and Applied Toxicology: Official Journal of the Society of Toxicology 33 83-90.

Curry S (1982) Methemoglobinemia. Annals of Emergency Medicine 11 214-221.

DuBois K, Kinoshita F and Frawley J (1968) Quantitative measurement of inhibition of aliesterases, acylamidase, and cholinesterase by EPN and Delnav ${ }^{8}$. Toxicology and Applied Pharmacology 12 273-284.

Eddleston M, Rajapakshe M, Roberts D, Reginald K, Sheriff MHR, Dissanayake W and Buckley N (2002) Severe Propanil [N-(3,4-dichlorophenyl) propanamide] Pesticide Self-Poisoning. Journal of Toxicology. Clinical Toxicology 40 847-854. 
Espey LL (1980) Ovulation as an inflammatory reaction--a hypothesis. Biology of Reproduction 22 73-106.

Frear DS and Still GG (1968) The metabolism of 3,4-dichloropropionanilide in plants. Partial purification and properties of an aryl acylamidase from rice. Phytochemistry 7 913-920.

Frost LL, Neeley YX, Schafer R, Gibson LF and Barnett JB (2001) Propanil inhibits tumor necrosis factor-alpha production by reducing nuclear levels of the transcription factor nuclear factor-kappa b in the macrophage cell line ic-21. Toxicology and Applied Pharmacology 172 186-193.

Gartrell MJ, Craun JC, Podrebarac DS and Gunderson EL (1986) Pesticides, selected elements, and other chemicals in adult total diet samples, October 1980-March 1982. Journal - Association of Official Analytical Chemists 69 146-159.

Hartmann DP, Holaday JW and Bernton EW (1989) Inhibition of lymphocyte proliferation by antibodies to prolactin. The FASEB Journal $32194-2202$.

Hellemans J, Mortier G, De Paepe A, Speleman F and Vandesompele J (2007) qBase relative quantification framework and software for management and automated analysis of real-time quantitative PCR data. Genome Biology 8 R 19.

Hoagland RE, Graf G and Handel ED (1974) Hydrolysis of 3',4'-dichloropropionanilide by plant aryl acylamidases. Weed Research 14 371-374.

Hoagland RE, Norsworthy JK, Carey F and Talbert RE (2004) Metabolically based resistance to the herbicide propanil in Echinochloa species. Weed Science 52 475-486.

Holásková I, Franko J, Goodman RL, Arnold AP and Schafer R (2015) The XX Sex Chromosome Complement is Required in Male and Female Mice for Enhancement of Immunity Induced by Exposure to 3,4-Dichloropropionanilide. American Journal of Reproductive Immunology 74 136-147.

Jacobson JD, Crofford LJ, Sun L and Wilder RL (1998) Cyclical expression of GnRH and $\mathrm{GnRH}$ receptor mRNA in lymphoid organs. Neuroendocrinology 67 117-125.

Johnson RD, Manske DD, New DH and Podrebarac DS (1984) Pesticide, metal, and other chemical residues in adult total diet samples. (XIII). August 1976September 1977. Journal - Association of Official Analytical Chemists $67154-$ 166.

Kaplan-Kraicer R, Bardin CW and Shalgi R (1995) Anordiol and RU486 synergize to produce preimplantation pregnancy loss by increasing embryo transport (rat). Contraception 51 141-146. 
Kojima H, Katsura E, Takeuchi S, Niiyama K and Kobayashi K (2004) Screening for estrogen and androgen receptor activities in 200 pesticides by in vitro reporter gene assays using Chinese hamster ovary cells. Environmental Health Perspectives 112 524-531.

Kosanke GJ, Schwippert WW and Beneke TW (1988) The impairment of mobility and development in freshwater snails (Physa fontinalis and Lymnaea stagnalis caused by herbicides. Comparative Biochemistry and Physiology Part C: Comparative Pharmacology 90 373-379.

Lahat N, Miller A, Shtiller R and Touby E (1993) Differential effects of prolactin upon activation and differentiation of human $B$ lymphocytes. Journal of Neuroimmunology 47 35-40.

Lewis TL, Brundage KM, Brundage RA and Barnett JB (2008) 3,4Dichloropropionanilide (DCPA) inhibits T-cell activation by altering the intracellular calcium concentration following store depletion. Toxicological Sciences: An Official Journal of the Society of Toxicology 103 97-107.

Lewis TL, Holásková I and Barnett JB (2013) The Toxicity of the N-Hydroxy and 6Hydroxy Metabolites of 3,4-Dichloropropionanilide Does Not Depend on Calcium Release-Activated Calcium Channel Inhibition. Toxicological Sciences 131 395405.

M. Richards, G. Y. H. McClure, T. L S (2001) Propanil (3,4-Dichloropropionanilide) Particulate Concentrations Within and Near the Residences of Families Living Adjacent to Aerially Sprayed Rice Fields. Archives of Environmental Contamination and Toxicology 41 112-116.

Malerba I (2002) In Vitro Myelotoxicity of Propanil and 3,4-Dichloroaniline on Murine and Human CFU-E/BFU-E Progenitors. Toxicological Sciences 69 433-438.

Matsunaka S (1968) Propanil Hydrolysis: Inhibition in Rice Plants by Insecticides. Science 160 1360-1361.

McClure GY, Helm RM, Stine K, Burks AW, Jones SM and Gandy J (2001) Evaluation of immune parameters in propanil-exposed farm families. Archives of Environmental Contamination and Toxicology 41 104-111.

McMillan DC, Leakey JE, Arlotto MP, McMillan JM and Hinson JA (1990) Metabolism of the arylamide herbicide propanil. II. Effects of propanil and its derivatives on hepatic microsomal drug-metabolizing enzymes in the rat. Toxicology and Applied Pharmacology 103 102-112.

McMillan DC, Bradshaw TP, Hinson JA and Jollow DJ (1991) Role of metabolites in propanil-induced hemolytic anemia. Toxicology and Applied Pharmacology 110 70-78. 
Melnikova VI, Lifantseva NV, Voronova SN and Zakharova LA (2019) GonadotropinReleasing Hormone in Regulation of Thymic Development in Rats: Profile of Thymic Cytokines. International Journal of Molecular Sciences 20.

Moller AT and Backstrom T (2016) Diurnal Variations of Endogenous Steroids in the Follicular Phase of the Menstrual Cycle. Neurochemistry \& Neuropharmacology 2.

Morse DL, Baker EL, Kimbrough RD and Wisseman CL (1979) Propanil-chloracne and methomyl toxicity in workers of a pesticide manufacturing plant. Clinical Toxicology 15 13-21.

Oakley OR, Frazer ML and Ko C (2011) Pituitary-ovary-spleen axis in ovulation. Trends in Endocrinology and Metabolism: TEM 22 345-352.

Owen JA, Punt J, Stranford SA, Jones PP and Kuby J (2013) Kuby Immunology. New York: W.H. Freeman.

Page-Wilson G, Smith PC and Welt CK (2006) Prolactin Suppresses GnRH but Not TSH Secretion. Hormone Research in Paediatrics 65 31-38.

Parborell F, Irusta G, Vitale A, Gonzalez O, Pecci A and Tesone M (2005) Gonadotropin-Releasing Hormone Antagonist Antide Inhibits Apoptosis of Preovulatory Follicle Cells in Rat Ovary. Biology of Reproduction 72 659-666.

Prado RD, Sanchez M, Jorrin J and Dominguez C (1992) Negative cross-resistance to bentazone and pyridate in atrazine-resistant Amaranthus cruentus and Amaranthus hybridus biotypes. Pesticide Science 35 131-136.

Pruett SB, Fan R, Zheng Q, Myers LP and Hébert P (2000) Modeling and Predicting Selected Immunological Effects of a Chemical Stressor (3,4Dichloropropionanilide) Using the Area under the Corticosterone Concentration versus Time Curve. Toxicological Sciences 58 77-87.

Rajesh RV, Balasubramanian AS and Boopathy R (2003) Identification of serotoninsensitive aryl acylamidase activity with cobra venom acetylcholinesterase. INDIAN J. BIOCHEM. BIOPHYS. 406.

Ratnasooriya WD and Perera PPDC (1997) Adverse effects of propanil on pregnancy outcome of rats. Medical Science Research 25 319-322.

Roberts DM, Heilmair R, Buckley NA, Dawson AH, Fahim M, Eddleston M and Eyer P (2009) Clinical outcomes and kinetics of propanil following acute self-poisoning: a prospective case series. BMC Clinical Pharmacology 93.

de la Rosa P, Barnett J and Schafer R (2003) Loss of pre-B and IgM(+) B cells in the bone marrow after exposure to a mixture of herbicides. Journal of Toxicology and Environmental Health. Part A 66 2299-2313. 
de la Rosa P, Barnett JB and Schafer R (2005) Characterization of thymic atrophy and the mechanism of thymocyte depletion after in vivo exposure to a mixture of herbicides. Journal of Toxicology and Environmental Health. Part A 68 81-98.

Salazar KD, de la Rosa P, Barnett JB and Schafer R (2005) The Polysaccharide Antibody Response after Streptococcus pneumoniae Vaccination Is Differentially Enhanced or Suppressed by 3,4-Dichloropropionanilide and 2,4Dichlorophenoxyacetic Acid. Toxicological Sciences 87 123-133.

Salazar KD, Miller MR, Barnett JB and Schafer R (2006) Evidence for a Novel Endocrine Disruptor: The Pesticide Propanil Requires the Ovaries and Steroid Synthesis to Enhance Humoral Immunity. Toxicological Sciences 93 62-74.

Salazar KD, Ustyugova IV, Brundage KM, Barnett JB and Schafer R (2008) A review of the immunotoxicity of the pesticide 3,4-dichloropropionanalide. Journal of Toxicology and Environmental Health. Part B, Critical Reviews 11 630-645.

Sancho E, Andreau Ó, Villarroel MJ, Fernández-Vega C, Tecles F, Martínez-Subiela S, Cerón JJ and Ferrando MD (2017) European eel (Anguilla anguilla) plasma biochemistry alerts about propanil stress. Journal of Pesticide Science 42 7-15.

Santillo M, Rippa C, Morte RD, Villani GRD, Santangelo F, Staiano N and Mondola P (1995) Enhancement of tissue lipoperoxidation in propanil-treated rats. Toxicology Letters 78 215-218.

Schafer R, Ognibene TJ, Malfatti MA, Turteltaub KW and Barnett JB (2018) Comparative Pharmacokinetics of High and Low Doses of the Herbicide Propanil in Mice. Chemical Research in Toxicology 31 1080-1085.

Schile A (2019) How mice are affected by the changing of seasons. In The Jackson Laboratory. https://www.jax.org/news-and-insights/jax-blog/2013/april/how-miceare-affected-by-the-changing-of-seasons. Accessed December 3, 2019

Schultz MJ, Speelman P, Zaat S, Deventer SJH van and Poll T van der (1998) Erythromycin Inhibits Tumor Necrosis Factor Alpha and Interleukin 6 Production Induced by Heat-Killed Streptococcus pneumoniae in Whole Blood. Antimicrobial Agents and Chemotherapy 42 1605-1609.

Senger PL (2012) Pathways to Pregnancy \& Parturition.Publisher: Current Conceptions, Inc. Redmond, OR.

Singh P, Krishna A, Sridaran R and Tsutsui K (2011) Immunohistochemical localization of $\mathrm{GnRH}$ and RFamide-related peptide-3 in the ovaries of mice during the estrous cycle. Journal of Molecular Histology 42 371-381.

Singleton SD and Murphy SD (1973) Propanil (3,4-dichloropropionanilide)-induced methemoglobin formation in mice in relation to acylamidase activity. Toxicology and Applied Pharmacology 25 20-29. 
Straub RH (2007) The Complex Role of Estrogens in Inflammation. Endocrine Reviews $28521-574$.

Stubelius A, Andersson A, Islander U and Carlsten H (2017) Ovarian hormones in innate inflammation. Immunobiology 222 878-883.

Torrealday S, Lalioti MD, Guzeloglu-Kayisli O and Seli E (2013) Characterization of the gonadotropin releasing hormone receptor (GnRHR) expression and activity in the female mouse ovary. Endocrinology 154 3877-3887.

Ustyugova IV, Frost LL, VanDyke K, Brundage KM, Schafer R and Barnett JB (2007) 3,4-Dichloropropionaniline Suppresses Normal Macrophage Function.

Toxicological Sciences 97 364-374.

Uthman E and Uthman E (1998) Understanding Anemia. Jackson, UNITED STATES: University Press of Mississippi.

Valentovic MA, Yahia T, Ball JG, Hong SK, Brown PI and Rankin GO (1997) 3,4Dicholoroaniline acute toxicity in male Fischer 344 rats. Toxicology 124 125-134.

Villarroel MJ, Sancho E, Ferrando MD and Andreu E (2003) Acute, chronic and sublethal effects of the herbicide propanil on Daphnia magna. Chemosphere 53 857-864.

Vitelli N, Chiodini A, Colosio C, De Paschale G, Somaruga C, Turci R, Minoia C, Brambilla $G$ and Colombi A (2007) [Occupational and environmental exposure to anilide and dicarboximide pesticides]. Giornale Italiano Di Medicina Del Lavoro Ed Ergonomia 29 276-277.

Watson VA, Barnett JB and Schafer R (2000) In vivo cytokine production and resistance to infection after acute exposure to 3,4-dichloropropionaniline. Journal of Toxicology and Environmental Health. Part A 60 391-406.

Weisburger JH and Weisburger EK (1973) Biochemical formation and pharmacological, toxicological, and pathological properties of hydroxylamines and hydroxamic acids. Pharmacological Reviews 25 1-66.

Williams $\mathrm{CH}$ and Jacobson $\mathrm{KH}$ (1966) An acylamidase in mammalian liver hydrolyzing the herbicide 3,4-dichloropropionanilide. Toxicology and Applied Pharmacology 9 495-500.

Wu Z-Q, Vos Q, Shen Y, Lees A, Wilson SR, Briles DE, Gause WC, Mond JJ and Snapper CM (1999) In Vivo Polysaccharide-Specific IgG Isotype Responses to Intact Streptococcus pneumoniae Are T Cell Dependent and Require CD40- and B7-Ligand Interactions. The Journal of Immunology 163 659-667.

Wu Z-Q, Khan AQ, Shen Y, Schartman J, Peach R, Lees A, Mond JJ, Gause WC and Snapper CM (2000) B7 Requirements for Primary and Secondary Protein- and 
Polysaccharide-Specific Ig Isotype Responses to Streptococcus pneumoniae. The Journal of Immunology 165 6840-6848.

Xie YC, Schafer R and Barnett JB (1997) Inhibitory effect of 3,4-dichloro-propionaniline on cytokine production by macrophages is associated with LPS-mediated signal transduction. Journal of Leukocyte Biology 61 745-752.

Yu-Lee L-Y (1997) Molecular Actions of Prolactin in the Immune System. Proceedings of the Society for Experimental Biology and Medicine 215 35-52.

Zhao W, Schafer R and Barnett JB (1998) Cytokine production by C57BL/6 mouse spleen cells is selectively reduced by exposure to propanil. Journal of Toxicology and Environmental Health. Part A 55 107-120.

Zhao W, Schafer R and Barnett JB (1999) Propanil affects transcriptional and posttranscriptional regulation of IL-2 expression in activated EL-4 cells. Toxicology and Applied Pharmacology 154 153-159. 